


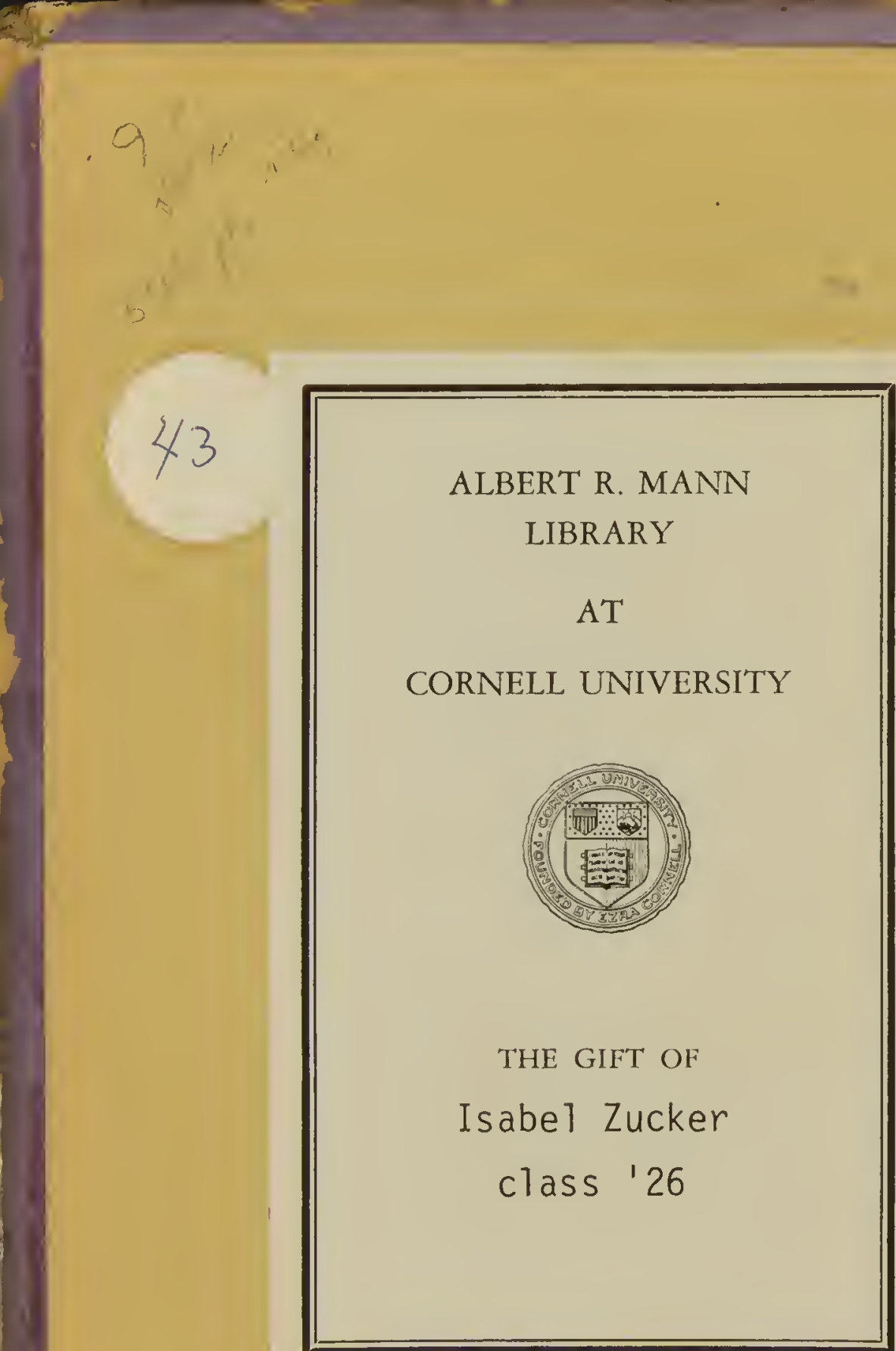









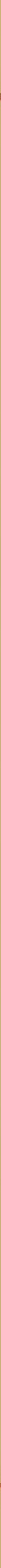


T H $\mathrm{I}$

\section{A N G U A GE}

ArD

\section{POETRY OF FLOWERS.}

WITII

Deautiful Illustrations

IN OIL COLORS.

WORLD PUBLISHING HOUSE,

I39 EIGHTH STREET, NEW YORK.

1876 . 


$$
\begin{aligned}
& \text { VAULT } \\
& \text { UNDER } \\
& P N \\
& 6110 \\
& \text { Flo } \\
& 1323 \\
& 1876
\end{aligned}
$$


PRE FA CE.

"I love God, I love little children, ] love the flowers," said a Persian, in vin. dication of his character as a true poet. Very few, in any time, possessing the "vision and the faculty divine," have failed to give such evidence of inspiration. In cottage and in palace, in every country, and in every age, flowers have been teachers and companions of the gentle and kind hearted; the truest language of love, the liveliest symbols of all holy thoughts and feelings.

This little volume contains some of the most beautiful popms which, from old Chaucer's time, has been written in our language about flowers. It is itself a "garden of poesies," which will not be unwelcome to any who love either sorg or nature. 



\section{CONTENTS}

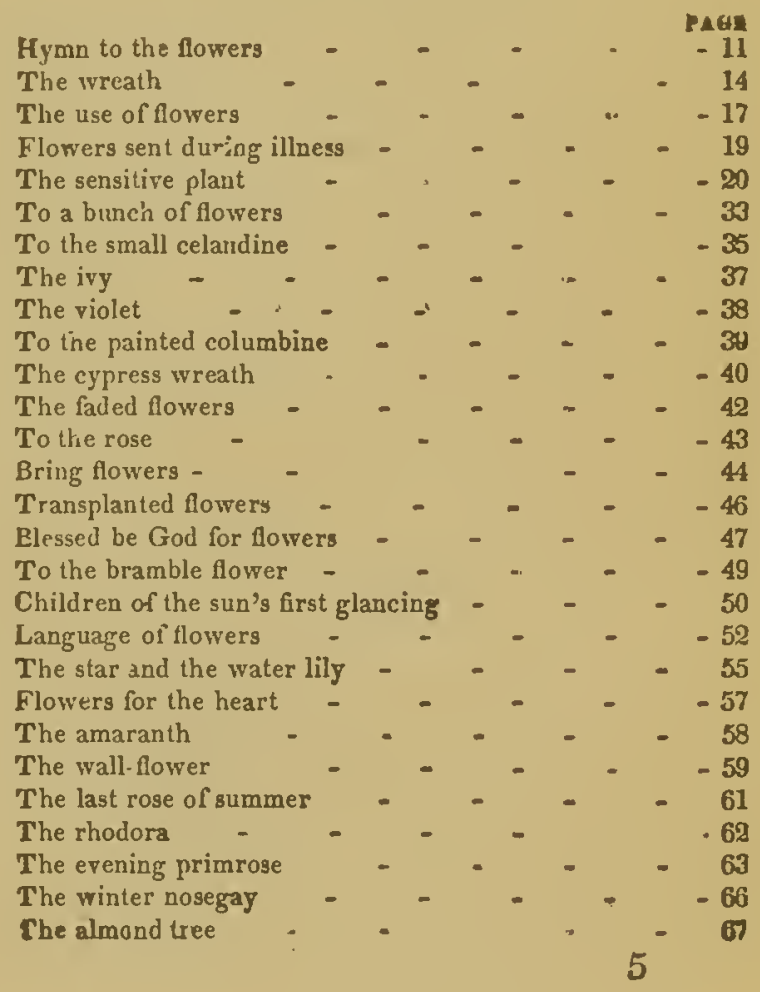


The lily - - $\quad$ - $\quad$ -

The larygeld - - 70

The Illy - - - . .

Cup.d and the dial - + - 79

The closed convolvulus - _ _ _ _ - 79

Human flowers - $\quad$ - $\quad$ - 74

The dying boy to the sloe blossom - - - 76

Songs and chorus of the flowers - $\quad-80$

The narcissus - $\quad$ - $\quad$ - $\quad$ - $\quad$ - 88

On receiring a branch of mezereon - _ - 89

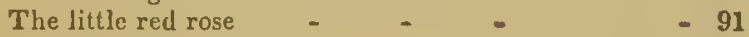

The roice of the flowers - $\quad$ _ $\quad$ - 92

Wild flowers - $\quad$ - $\quad$ - $\quad$ - $\quad . \quad-95$

Cupid inspiring plants with love $\quad$ - $\quad$ - 97

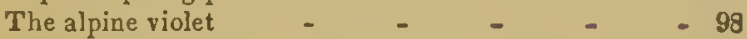

To a daisy - $\quad$ - $\quad$ - 99

The ivy song - $\quad-\quad-\quad-\quad+\quad-100$

Daffodils - - $\quad$ - $\quad$ - $\quad$ - 102

Adonis' couch - _ _ _ _ - 103

Flower fantasies - $\quad$ - $\quad$ - $\quad$ - 105

Sonnet - - $\quad$ - $\quad$ - $\quad$ - $\quad$ - $\quad-108$

The flower dial - $-\quad, \quad+\quad-109$

Spring flowers - $\quad$ - $\quad \ldots \quad-110$

Bowing adorers - $\quad-\quad+\quad-111$

Fragment - - - + - - 112

To a mountain daisy _ _ - - $\quad 112$

The broken flower . . . $\quad-115$

To the sunflower - _ _ - 116

The rose and the gauntlet - _ - 117

The rose - - - - 119

Hcart's ease - - . . - 120

The moss rose - $\quad . \quad+\quad . \quad 121$

The hyacinth - . . . 192

Flowers for the grave 


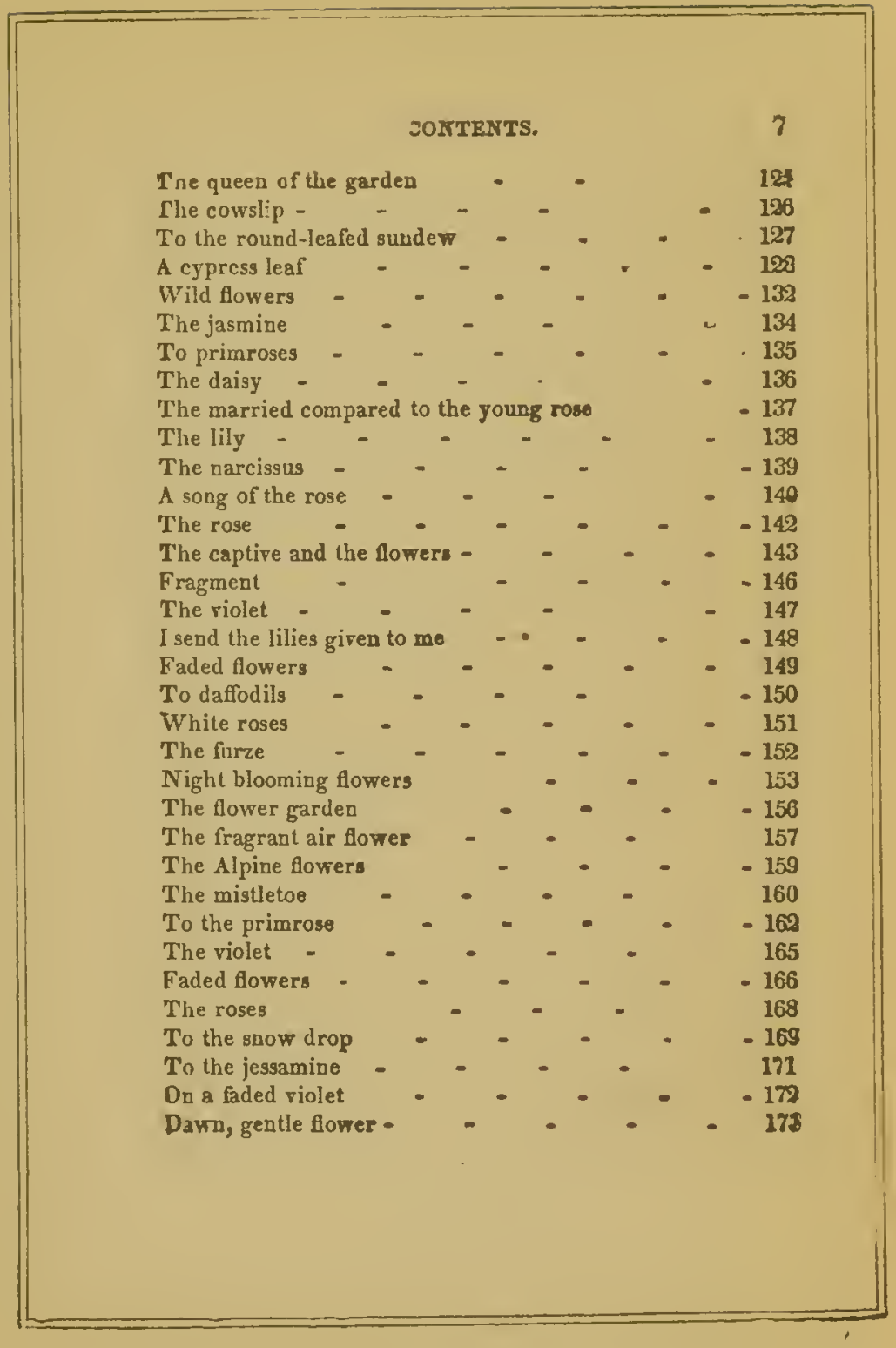


The lily and the rese - $\quad$ - $\quad$ - 174

The violet - - - . 175

The dying girl and fowers - $\quad$ - $\quad 176$

The nightshade $\quad-\quad$ - $\quad . \quad$ - $\quad 178$

The lay of the rose $\quad-\quad[\quad-\quad \ldots \quad-179$

Emblems of flowers - $\quad$ - $\quad$ - $\quad$ - 188

The orange bough $\quad-\quad-\quad-189$

To the varcissus - - - - $\quad 190$

The harebell - - _ _ . - - 121

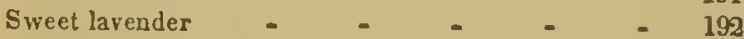

The half-blown rose $\quad-\quad \ldots \quad+\quad . \quad-193$

To the daisy - $\quad$ - $\quad$ - $\quad$ - $~ 194$

Love's wreath - - _ _ _ _ - 197

To a crocus - - $\quad$ - $\quad$ - $\quad$ - 198

Arrangements of a bouquet $\quad-\quad \ldots \quad-200$

Dn planting a tulip - $\quad$ - $\quad$ - $\quad 202$

To blossoms - - . - - - - - 203

A comparison - $\quad$ - $\quad$ - $\quad$ - $\quad 204$

The early primrose $\quad \ldots \quad \ldots \quad-\quad-205$

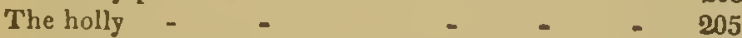

The narcissus $\quad-\quad \ldots \quad . \quad \ldots \quad-\quad-208$

Anacreon to the rose $\quad$ - $\quad$ - 207

Decision of the flower - _ _ _ . 208

The snow-drop - $\quad$ - $\quad$ - $\quad 209$

Daffodils - . - . . . . . 210

The shepherd to the flowers _ _ - 211

Heart's ease - - . . . . . 21\%

The scarlet geranium _ _ _ _ $\quad 21 \mathrm{~s}$

The heliotrope - - $\quad . \quad+\quad .215$

Amour of the rose - _ _ _ _ - 215

The forget-me-not - _ _ _ 216

Field leaves - _ _ _ _ _ 217

The Indian jasmine fower - _ _ . - 218

The evening primurose $\quad$. . 219 


\section{CONTHNT.}

To an early primrose - _ - _

The rose-bud - + - _ - 222

The garland . $. \quad . \quad . \quad . \quad-275$

The field-flowers - . . . 297

To the snow-drop _ _ _ $\quad-229$

Cowslips - _ - _ _ _ 231

Heart's ease - _ _ _ _ - - 234

To the sweet-brier - _ - _ _ - 235

A mother's dirge orer her child _ - $\quad-236$

The rose - - - . - - 238

Go to the forest shado - _ _ _ _ $\quad$ - 239

To a jasmine tree - _ _ _ _ 242

April flowers - $\quad$ - $\quad . \quad-\quad-243$

Flowers - - - - - - - 245

The orchis - - _ - $\quad$ -

The daisy in India - _ _ _ $\quad 248$

The primrose of the rock $\quad-\quad-250$

The rose - _ _ . . 252

The riolet - _ _ - -253

Field flowers _ _ _ _ _ - 255

In eastern lands - $\quad-\quad \ldots \quad-\quad . \quad-257$

The honey suckle - _ _ - - 258

To a snow-drop - _ _ . . _ .

To the passion flomer _ _ _ - 201

The lily of the valley - - _ - -263

The flower garden - _ _ _ - 266

The Language of Flowers, - - - 267 



\section{VIS. \\ POETRY OF FLOWERS.}

\section{HYMN TO THE FLOWERS.}

BY HORACE SMITH.

DAY-STaRs! that ope your eyes with man, to twinkle

From rainbow galaxies of earth's creation, And dew-drops on her holy altars sprinkle As a libation.

Ye matin worshippers! who bending rowly Before the uprisen sun, God's lidless eye ! Throw from your chalices a sweet and holy Incense on high.

Yo bright Mosaics! that with storied beauty The floor of nature's temple tesselate With pumerous emblems of instructive duty Your forms create. 
Neath cloistered boughs, eaeh floral bell tha swingeth,

And tolls its perfume on the passing air, Makes sabbat!. in the fields, and ever ringeth A eall to prayer.

Not to the domes where erumbling areh and eolumn

Attest the feebleness of mortal hand, But to that fane, most eatholic and solemn, Whieh God hath planned.

To that eathedral, boundless as our wonder,

Whose quenehless lamps the san and moon supply ;

Its choir the winds and waves-its organ thunderIts dome the sky.

There as in solitude and shade I wander,

Through the green aisles, or stretehed upon the sod,

Awed by the silence, reverently ponder The ways of God.

Your voiceless lips, O flowers! are living preaeh ers,

Each cup a pulpit, and each leaf a book Bupp?ying to my faney numerous teacheru From loneliest nook. 
Foral apostles! that in dewy splendour,

"Weep without woe, and blush without crime,"

O may I deeply learn, and ne'er surrender Your lore sublime!

"Thou wert not, Solonion! in all thy glory; Arrayed," the lilies cry, "in robes like ours; How vain your grandeur! ah, how transitory, Are human flowers!"

In the sweet scented pictures, heavenly Artist! With which thou paintest nature's wide-spread hall,

What a delightful lesson thou impartest

Of love to all !

Not useless are ye, flowers! though made for pleasure,

Blooming o'er field and wave by day and night, From every source your sanction bids me treasure Harmless delight.

Ephemeral sages ! what instructors hoary For such a world of thought could furnish scnpe Each fading calyx a memento mori, Yet fount of hope.

Posthumous glories ! angel.llike collection ! Upraised from seed or bulb interred in earth, 
Ye are to me a type of resurrection, A second birth.

Were I, O God! in churchless lands remaining

Far from all voice of teachers or divines,

My soul would find in flowers of thy ordai ing,

Priests, sermons, shrines !

\section{THE WREATH.}

TO A FRIEND ON HER BIRTHDAY.

BY WILLIAM PETERS.

CET others sing the rich, the great, The victor's palms, the monarch's state,

A purer joy be mine-

To greet the excellent of earth, To call down blessings on thy worth, And, for the hour that gave thee birth, Life's choicest flowers entwine.

And lo! where snuling from above (Meet helpmatc in the work of love: O'er opening hill and lawr, With flowerets of a thousand dyes, Wit's all that's swect of earth and skies, Soft breathes the vernal dawn 
Come ! from her stores we'll cull the bea Thy bosom to adorn;

Each leaf in livelier verdure dxest, Fach blossom balmier than the rest,

Each rose without a thorn;

Fleet tints, that with the rainbow died, Brief flowers, that withered in their pride. Shall, blushing into light, awake And kindlier bloom, for thy dear sake.

And first-though aft, alas! condemand, Like merit, to the shade-

The Primrose meek, with dews begemand, Shall sparkle in the braid: And there, as sisters, side by side, (Genius with modesty allied,) The Pink's bright red, the Violet's blue. In blended rays, shall greet our view, Each lovelier for the other's hue.

How soft yon Jasmine's sunlit glow, How chaste yon Lily's robe of snow,

With Myrtle green inwove, Types, dearest, of thyself and meOf thy mild grace and purity, Aud my unchanging love, Of grace and purity, like thine, And love, undying love, like mine 
In fancifully plumed array,

As ever cloud at set of day,

All azure, vermil, silver-gray

And showering thick perfume,

See ! how the Lilac's clustered spray

Has kindled into bloom,

Radiant, as Joy, o'er troubles past,

And whispering, Spring is come at last!"

Blest Flowers! Tnere breathes not one unfra'igh

With lessons sweet and new ;

The Rose, in 'Taste's own garden wrought;

The Pansy, nurse of tender thought;

The Wall-flower, tried and true;

The purple Heath, so lone and fair,

1O, how unlike the world's vain glare!)

The Daisy, so contently gay,

Opening her eyelids with the day;

The Gorse-bloom, never sad or sere,

But golden-bright,

As gems of night,

And fresh and fragrant, all the year;

Each leaf, each bud, of classic lore,

Oak, Hyacinth, and Floramore ;

The Cowslip, graceful ir. her woe;

The Hawthorn's smile, the Poppy's glow,

This ripe with balm for present sorrow,

And that, with raptures for to-morrow. 
The flowers are culled; and each lithe ster.

With Woodbine band we brajd-

With Wodbine, type of Life's best gem, Of 'Truth, that will not fade:

The Wreath is wove; do 'I'hou, blest Power, That brood'st o'er leuflet, fruit, and flower,

Embalm it with thy love ;

$\mathrm{O}$ make it such as angels wear,

Pure, bright, as deck'd earth's first-born pair,

Whilst, free in Eden's grove,

From herb and plant they brushed the dew, Anz serther sin nor sorrow knew.

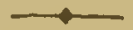 \\ THE USE OF FLOWERS.}

BY MARY HOWITT.

GoD might have bade the earth bring forth

Enough for great and small,

The oak-tree and the cedar-tree,

Without a flower at all.

He might have made enough, enough̆,

For every want of ours ;

For luxury, medicine, and toil,

And yet have made no flowers

The ore withn the mountain-mue

Requireth none to grow, 
Nor doth it need the lotus flower To make the river flow

The clouds might give abundant rair, The nightly dews might fall, And the herb that keepeth life in man Might yet have drund them all.

Then, wherefore, wherefore were they rase All dyed with rainbow light; All fashion'd with supremest grace, Up-springing day and night ;

Springing in valleys green and low, And on the mountains high, And in the silent wilderness, Where no man passes by ?

Our outward life requires them not-w Then wherefore had they birth $?$

To minister delight to man, To beautify the earth ;

To comfort man-to whisper hope Whene'er his faith is dim;

For who so careth for the flowere. Will much more care for birni 
TEB P JETRY OF FLOWERS.

\section{FLOWERS:}

SENT ME DURING ILINESS.

BY RICHARD H. DANA.

1. loved you ever, gentle flowers, And made you playinates of my youth;

The while your spirit stole

In secret to my soul,

I'o shed a softness through my ripening powern

And lead the thonghtful mind to deepest truth.

And now, when weariness and pain

Had cast you almost from my breast,

With each a smiling face,

In all your simple grace,

You come once more to take me back again

From pain to ease, from weariness to rest.

Kind visitants! through my sick room

You seem to breathe an air of health,

And with your looks of joy

To wake again the boy,

And to the pallid cheek restore its bloom, And o'er the desert mind pour boundless wealth.

And whence ye came, by brimming stream, 'Neath rustling loaves, with birds within. 
A gain 1 musing tread-

Forgot my restless bed,

And long, sick hours.-Too short the blessed dream!

I woke to pain!-to hear the city's din!

But time nor pain shall ever steal

Or youth or beaxty from my mind,

And blessings on ye, Flowers .

Though few with me your hours,

The youth and beauty, and the heart to feel,

In her who sent you, ye will leave behind!

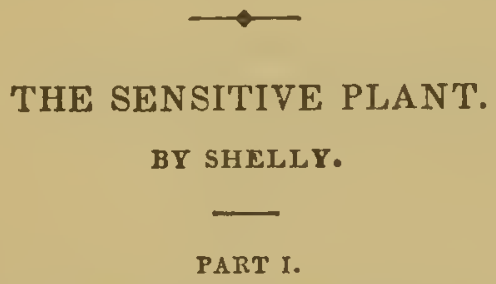

A sensitive plant in a garden grew, And the young winds fed it with silver dew; And it open'd its fan-like leaves to the light, And closed them beneath the kisses of night.

And the spring arose on the garden fair, Like the spirit of love, felt every where ! And each flower and herb on earth's dark breact Re from the dreams of its wintry rest. 
The snow -drop, and then the violet, Arose from the ground with warm rain wet; And thcir breath was mix'd with fiesh odour, sent From the turf, like the voice to the instrument.

Then the pied wind-flowers, and the tulip tall, And narcissi, the fairest among them allWho gaze on their eyes in the stream's recess, Till they die of their own dear loveliness!

And the naiad-like lily of the vale, Whom youth makes so fair, and passion so palo. That the light of its tremulous bells is seen Through their pavilioss of tender green;

And the liyacinth, purple, and white, and blue, Which flung from its bells a sweet peal anew of music so delicate, soft, and intense, It was felt like an odour within the sense:

And the rose like a nymph to the bath addrest, Which unveil'd the depth of her glowing breast, Till, fold after fold, to the fainting air The soul of her bcauty and love lay bare;

And the wand-like lily, which lifted up, As a Mænad, its moonlight-colour'd cup, Till the fiery star, which is its eye, Gazed through vlear df/w on the tender sky. 
And the jessamine fant, and the sweet tuberon; The sweetest flower for scent that blows! And all rare blossoms, from every eline, Grew in that garden in perfect prime.

And on the stream whose ineonstant bosom Was prankt, under boughs of embowering blos, som,

With golden and green light, and starting through Their heaven of many a tangled hue,

Broad water-lilies lay tramulously, And starry river-buds glimmer'd by, And around them the soft stream did glide ard dance

With a motion of sweet sound and radianee.

And the sinuous paths of lawn and moss, Which led through the garden along and aerossSome open at onee to the sun and the breeze, Some lost among bowers of blossoming trees-

Were all paved with daisies and delieate bells As fair as the fabulous asphodels, And flowerets wisich drooping as day droop'd toa Fell into pavilnns white, purple, and blue, To roof the glow-worm from the evening dew.

And from this undefiled paradise

The flowers (as an infant's awakening eyes 
Snile on its mothcr, whosc singing sweet

Can first lull, and at last must awaken it?,

When heaven's blithe winds had unfolded them As mine lamps enkindle a hidden gem, Shone smiling to licaven, and every one Shared joy in the light of the gentle sun;

For each one was interpenetrated

With the light and the odour its neighbour shed, Like young lovers whom youth and love make dear,

Wrapp'd and fill'd by their mutual atmosphere.

But the sensitive plant, which could give small fruit

Of the love which it fclt from the leaf to the root, Received more than all, it loved more than ever, Where none wanted but it, could belong to the giver.

For the sensitive plant has no bright flower; Radiance and odour are not its dower; It loves, even like Isove; its deep hoart is full; It desires what it has not, the beautiful ?

The light winds, which from unststaining wings Shed the music of many murmurings ; The beams which dart from many a star of the dlowers whose hucs they bear afar: 
The plumed insects swift and free, Like golden boats on a sunny sea, Laden with light and odour, which pass Over the gleam of the living grass;

The unseen clouds of the dew, which lie Like fire in the flowere till the sun rides high, Then wander like spirits among the spheres. Each cloud faint with the fragrance it bears;

The quivering vapours of dim noon-tide, Which like a sea o'er the warm earth glide, In which every sound, and odour, and beam. Move, as reeds in a single stream;

Each and all like ministering angels were For the sensitive plant sweet joy to bear, Whilst the largging hours of the day went by Like windless clouds o'er a tender sky.

And when evening descended from heaven a'sove And the earth was all rcst, and the air was all love,

And delight, though less bright, was far more deep,

And the day's veil fell from the world of sleep;

And the beasts and the birds, and the insect were drown'd

In an ocean of dreams wi.hout a sound; 
Whose waves never maris though they ever impress

The light sand which paves it, conscionsness;

Only overhead the sweet nightingale

Ever sang more sweet as the day might fail,

And snatches of its Elysian chant

Were mix'd with the dreams of the sensitive plant ;)

The seneitive plant was the earliest Up-gathrr'd into the bosom of rest; A swert child weary of its delight, The ferlust and yet the favourite, Cradlp? within the embrace of nigis

\section{PART II.}

The? ? was a power in this sweet place, An Five in this Eden; a ruling grace Which to the flowera, did they waken or dream, Was as God is to the starry scheme:

A lady, the wonder of her kind, Whose form was upborne by a lovely mind, Which, dilating, had moulded her inien and motion

ike a sea-tlover unfoliled beneath the ocean, 
Tenaed the garden from morn to even; And the meteors of that sublumar heaven, Like the lamps of the air when night walks "orths Laugh'd round her footsteps up fiom the earth!

She had no companion of mortal race, But her tremulous breath and her flushing face Told, whilst the morn kiss'd the sleep from her eyes,

That her dreams were less slumber than paradise,

As if some bright spirit for her sweet sake Had deserted heaven while the stars were awake, As if yet around her he lingering were,

Though the veil of daylight conceal'd him from her.

Her step seem'd to pity the grass it prest; You might hear, by lhe heaving of her breast, That the coming and the going of the wind Brought pleasure there, and left passion behind,

And wherever her airy footstep oud, Her trailing hair from the grassy sod Erased its light vestige, with shadowy sweep, Like a sunny storm o'er the dark green deep.

I doubt not the flowers of that garden sweet Rejoiced in the sound of her gentle feet: 
THE POETKY OF FLOWERS.

I doubt not they felt the spirit that came

From her glowing fingers through all thair irame

She sprinkled bright water from the stream On those that were faint with the sunny beam; And out of the cups of the heavy flowers She emptied the rain of the thunder showers.

She lifted their heads with her tender hands, And sustain'd them with rods and osier bands; If the flowers had been her own infants, she Could never have nursed them more tenderly.

And all killing inseets and gnawing worms, And things of obseene and unlovely forms, She bore in a basket of Indian woof Into the rough woods far aloof.

In a basket, of grasses and wild flowers full, 'The freshest her gentle hands eould pull For the poor banish'd insects, whose intent, Although they did ill, was innoeent.

But the bee and the beam-like ephcmeris, Whose path is the lightning's and soft moths taat liss

The sweet lips ot the flowers, and harm not, did she

Make bor attendant angels be. 
And nuany an antenatal tomb,

Whore butterflies dream of the life to come, She left clinging round the smooth and dark Edge of the odorous cedar bark.

This fairest creature from earliest spring Thus moved through the garden ministering, All the sweet season of the summer-tide, And ere the first leaf look'd brown-she died

\section{PART III.}

Three days the flowers of the garden fair, Like stars when the noon is awaken'd, were, Or the waves of the Baiæ, ere luminous She floats up through the smoke of Vesuvius.

And on the fourth, the sensitive plant Felt the sound of the funeral chant, And the steps of the bearers, heavy and slow, And the sobs of the mourners, deep and low.

The weary sound and the heavy breath, And the silent motions of passing death, And the smell, cold, oppressive, and dank, Sent through the pores of the coffin plank;

The dark grass, and the flowers among the grass, Were bright with tears as the crowds did pass 
From their sighs ihe wind caught a mournfus tone, And sate in the pines, and gave groan for groan.s

The garden, once fair, became cold and foul, Like the eorpse of her who had been its soul: Which at first was lovely as if in sleep, Then slowly ehanged, till it grew a heap To make men tremble who never weep.

Swift summer into the altumn flow'd, And frost in the mist of the morning rode, Though the noon-day sun look'd clear and bright, Mocking the spoil of the seeret night.

The rose-leaves, like flakes of crimson snow, Paved the turf and the moss below; The lilies were drooping, and white, and wan, Like the head and the skin of a dying man.

And Indian plants, of scent and hue The sweetest that ever were fed on dew, Leaf after leaf, day by day, Were massed into the common clay.

And the leaves, brown, yellow, and gray and red And white with the whiteness of what is dead, Like troops of ghosts on the dry wind pass'd; Their vlistling noise made the birds aghast. 
And tho gusty winds waked the winged seeds Out of their birth-place of ugly weeds, Till thcy clung round many a sweet flower's stem Which rotted into the earth with them.

The water-blooms under the rivulet Fell fiom the stalks on which they were set; And the eddies drove them here and there, As the winds did those of the upper air.

Then the rain eame down, and the broken stalk, Were bent and tangled across the walks; And the leafless net-work of parasite bowers Mass'd into ruin, and all sweel flowers.

Between the time of the wind and the snow, All loathliest weeds began to grow, Whose coarse leaves were splash'd with many speck,

Like the water-snake's belly and the toad's back

The sensitive plant, like one forbid, Wept, and the tears within each lid Of its folded leaves, which together grew, Were ehanged to a blight of fiozen glue.

For the leaviss soon fell, and the branches soon By the heavy axe of the blast were liewn; The sap shrank to the root through every pore, As blood to a heart that will beat no mcro. 
For Winter came: the wind was his wh.1p One choppy finger was on his lip:

He had torn the cataracts from the hills, And they clank'd at his girdle like manac_es.

His breath was a chain which, without a sound, The earth, and the air, and the water bound; He came, fiercely driven in his chariot throne By the tenfold blasts of the arctic zone.

Then the weeds which were forms of living death, Fled from the frosts to the earth beneath: Their decay and sudden fight from frost, Was but like the vanishing of a ghost!

And under the routs of the sensitive plant The moles and the dormice died for want; And the birds dropp'd stiff from the frozen air, And were caught in the branches naked and bare.

First there came down a thawing rain, And its dull drops froze on the boughs again, Then there stcam'd up a freezing dew Which to the drops of the thaw-rain grcw;

And a northern whirlwind, wandering about Liks a wolf that had smelt a dead child out, Shook the boughs thus laden and heavy and stiff And sunpp'd them off with his rigid griff. 
When winter had gone and spring came back, The sensitive-plant was a leafless wreck; But the natandraks, and toadstools, and dock and darnels,

Rose like the dead from their buried charnols.

CONCLUSION.

Whether the sensitive plant, or that

Which within its boughs like a spirit sat, Ere its outward form had known decay,

Now felt this change, I cannot say.

Whether that lady's gentle mind, No longer with the form combined, Which scattel'd love, as stars do light, Found sadness where it left delight,

I dare not guess; but in this life Of error, ignorance, and strife, Where nothing is, but all things seem, And we the shadows of the dream.

It is a modest creed, and yet Pleasant, if one considers it, To own that death itself must be, Like all the rest, a mockery.

Tha: garden sweet, that lady fair, And all sweet shapes and odours there. 


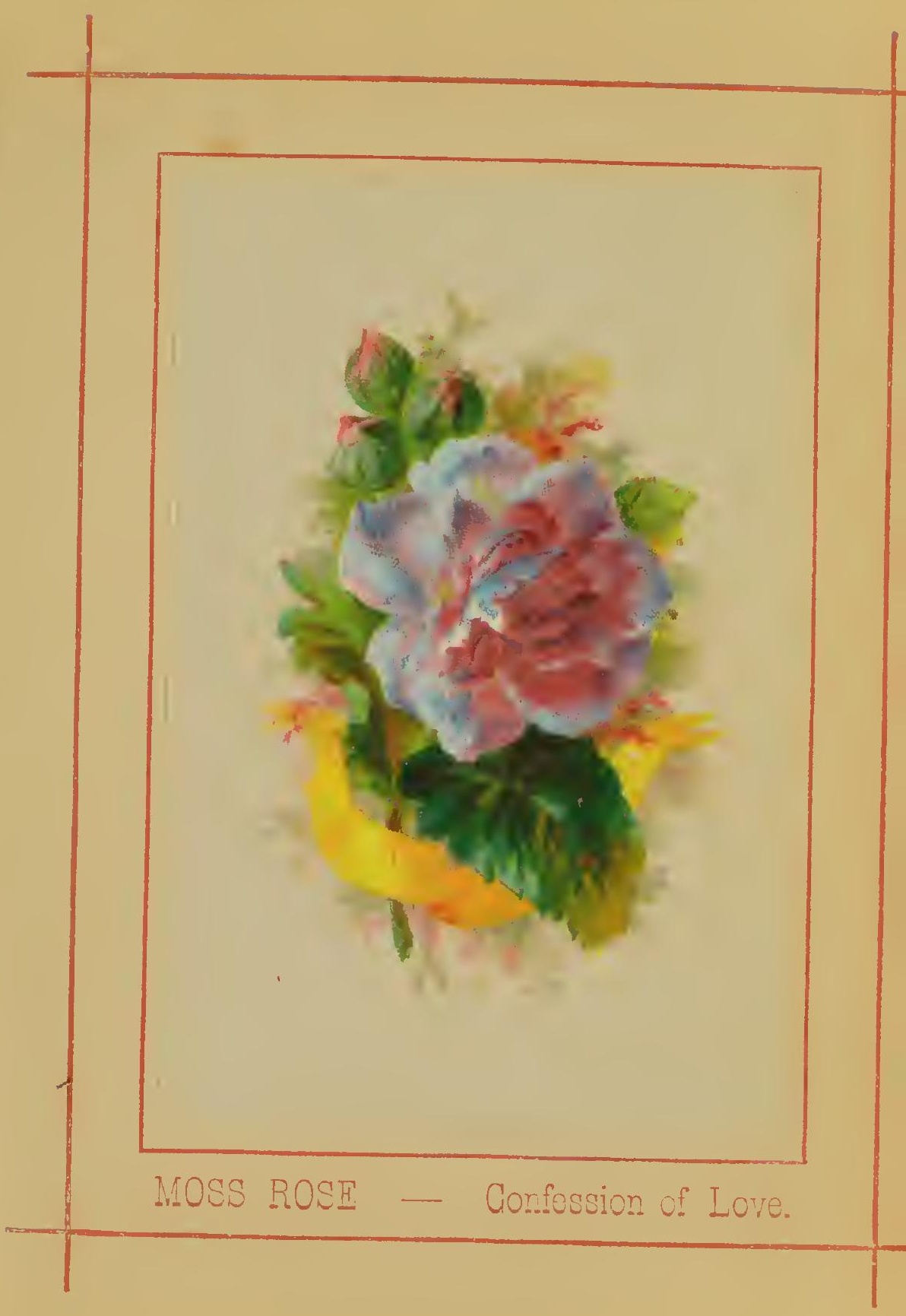



THE POETRY SF F: OWERS.

In truth, have never pass'd away :

'Tis we, 'tis ours, are changed! not they.

For love, and beauty, and delight,

There is no death nor change; their might

Exceeds our organs, which endure

No light, being themselves obscure.

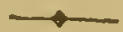

TO A BUNCH OF FLOWERS.

BY. REV . JAMES F. CLARKE.

LitTLE firstlings of the year !

Have you come my room to cheer?

You are dry and parched, I think;

Stand within this glass and drink;

Stand besidc me on the table,

'Mong my books-if I am able,

I will find a vacant space

For your bashfulness and grace;

Learned tasks and serious duty

Shall' be lightened by your beauty.

Pure affection's sweetest token,

Clioicest hint of love unspoken,

Friendship in your help rejoices,

Lttering her mysterious voices.

You are gifts the poor may offer-

Wealth can find no better proffer 8

For you tell of tastes refined,

Thoughtful heart and spiris kind.

3 
Gift of gold or jewel dresses

Ostentation's thought confesser :

Simplest mind this boon may give,

Modesty herself receive.

For lovely woman you were meas

The just and natural ornament,

Sleeping on lier bosom fair,

Hiding in her raven hair,

Or, peeping out mid golden curls,

You outshine barbaric pearls;

Yet you lead no thought astray,

Feed not pride nor vain display,

Nor disturb her sisters' rest,

Waking envy in their breast.

Let the rich, with heart elate,

Pile their board with costly plate

Richer ornaments are ours,

We will dress our home with flowers?

Yet no terror reed we feel

Lest the thief break through to steal

$Y$ e are playthings for the child,

Gifts of love for maiden mild,

Comfort for the aged eye,

For the poor, cheap luxury.

Though your life is but a day,

Precious things, dear flowers, yoll say,

Telling that the Being good

Who supplies our daily food,

Deems it needful to supply

Daily food for heart and eye. 
Bo, though your lfe is but a day, We grieve not at your swift decay; $\mathrm{He}$, who smiles in your bright faces, Sends us more to take your places;

'Tis for this ye fade so soon, That he may renew the boon:

That kindness often may repeat These mute messages so sweet: That Love to plainer speech may get, Conning oft his alphabet;

That beauty may be rain'd from heaven, New with every morn and even, With freshest fragrance sunrise greeting Therefore are ye, flowers, so fleeting.

\section{TO THE SMALL CELANDINE.}

\section{WORDSWORTH.}

Pansies, lilies, king-cups, daisies, Let them live upon their praises; Long as there's a sun that sets, Primroses will have their glory ; Long as there are violets, They will have a place in story: There's a flower that shall be mine, 'Tis the little Celandine. 
Ere a leaf is on a bush, In the time before the thrush Has a thought about her nest, Thou wilt come with half a call, Spreading out thy glossy breast Like a careless prodigal;

Telling tales about the sun,

When we've little warmth, or non

Comfort have thou of thy merit, Kindly unassuming Spirit!

Careless of thy neighbourhood, Thou dost show thy pleasant face On the moor, and in the wood, In the lane;-there's not a place,

Howsoever mean it be, But 'tis good enough for thee.

Ill befall the yellow flowers,

Children of the flaring hours!

Butter-cups that will be seen, Whether we will see or no; Others, too, of lofty mien; They have done as worldlings do, Taken praise that should be thine, Little, humble Celandine!

Prophet of delight and mirth Ill requited upon earth ; Herald of a mighty band, Of a joyous train ensuing, 
Serving at my heart's command,

Tasks that are no tasks renewing,

I will sing, as doth behove,

Hymns in praise of what I love!

\section{THE IVY.}

\section{BARTON.}

HAst thou seen, in winter's stormiest day,

$\mathrm{T}$ he trunk of a blighted oak,

Not dead, but sinking in slow decay

Beneath time's resistless stroke,

Round which a luxuriant ivy had grown,

And wreathed it with verdure no ionger its own?

Perchance thou hast seen this sight, and then, As I at thy years might do,

Pass'd carelessly by, nor turn'd again

That scathed wreck to view.

But now I can draw from that mouldering tree Thoughts which are soothing and dear to me.

O smile not! nor think it a worthless thing, If it be with instruction fraught;

That which will closest and longest cling

Is alone worth a serious thought !

Should aught be unlovely which thus can shed Grace on the dying, and leaves on the dead? 


\section{THE VIOLET.}

FHOM THE GERMAN OF GOETHW

A violet blossom'd on the green, With lowly stem, and bloom unseen: It was a sweet, low flower.

A shepherd maiden came that way, With lightsome step and aspect gay,

Came near, came near, Came o'er the green with song.

Ah ! thought the violet, might I be The fairest flower on all the lea, Ah ! but for one brief hour ; And might be plucked by that dear maid, And gently on her bosom laid, Ah! but, ah! but

A few dear moments long.

Alas ! the maiden, as she pass'd, No eye upon the violet cast : She crush'd the poor, wee flower; It sank, and dying, heaved no sigh, And if I die, at least I die By her, by her, Bencath her feet I die. 


\title{
TC THE PAINTED COLUUIBINE.
}

\author{
BY JONES VERY.
}

Briant image of the early years

When glow'd my cheek as red as thou, And life's dark throng of cares and fears Were swift-winged shadows o'er my sunny brow!

Thou blushest from the painter's page,

Robed in the mimic tints of art;

But Nature's hand in youth's green age With fairer hues first traced thee on my heart.

The morning's blush, she made it thine, The morn's sweet breath, she gave it theo; And in thy look, my Columbine!

Each fond-remember'd spot she bade me see.

I see the hill's far-gazing head,

Where gay thou noddest in the gale;

I hear light-bounding footsteps tread

The grassy path that winds along the vale.

I hear the voice of woodland song

Breals from each bush and well-known tree, And, on light pinions borne along,

somes back the laugh from childhood's heart of glee. 
O'e the dark rock the dashing brook,

With look of anger, leaps again,

Ana hasiening to each flowery nook,

Its distums voice is heard far down the glen,

Fair clild of art! thy charms decay,

Touched by the wither'd hand of Time:

And hushed the music of that day,

When my voice mingled with the streamlet'w chime;

But on my heart thy cheek of bloom

Shall live when Nature's smile has fled;

And rich with memory's sweet perfume,

Shall o'er her grave thy tribute incense shed.

There shalt thou live and wake the glee

That echoed on thy native hill;

And when, loved flower! I think of thee,

My infant feet will seem to seek thee still.

THE CIPRFSS WREATH.

BY SIR W. SCOTT.

O LADY, ewine no wreath for me,

Or twine it of the cypress-tree !

Too lively glow the lilies light,

The varnish'd holly's all too I ight, 
The May-flower and the eglantine May shade a brow less sad than mine; But, lady, weave no wreath for me, Or weave it of the cypress-tree.

Let dimpled Mirth his temples twine With tendrils of the laughing vine; The manly oak, the pensive yer, To patriot and to sage be due; The myrtle bough bids lovers live, But that Matilda will not give; Then, lady, twine no wreath for me, Or twine it of the cypress-tree.

Let merry England proudly rear Her blended roses, bought so dear; Let Albin bind her bonnet blue With heath and harebell dipp'd in dew ; On favour'd Erin's crest be seen The flower she loves of emerald greenBut, lady, twine no wreath for me, Or twine it of the cypress-tree.

Strike the wild harp, while maids prepare The ivy meet for minstrel's hair ; And while his crown of laurel leaves With bloody hand the victor weaves, Let the loud trump his triumph tell; But when you hear the passing bell, Then, lady, twine a wreath for me, And twine it of the cypress-trea. 
Yes! tivine for me the cypress bough ;

But, O Matilda. twine not now-

Stay till a few brief months are pasi,

And I have look'd and loved my last !

When villagers my shroud bestrew

With pansies, rosemary, and rue,-

Then, lady, weave a wreath for ine,

And weave it of the cypress-tree.

\section{$\longrightarrow$ \\ THE FADED FLOWERs.}

BY. REV. WALTER COLTON, U. S. K.

TC THE LADY WHO PRESENTED THE AUTHOR WITA

A CLUSTER OF FADED FLOWERS.

Triese faded flowers a softer grief

Than blooming ones beget;

More tender now on each pale leaf

The tints that linger yet:

For all the charms, that cheer'd the past,

Hang round these hues that fade the last.

The morn they had their fragrant birth,

The wild shrubs where they grew,

The bee that in its matin mirth

Hung over their pearls of dew,

Must. share alike the floweret's lot,

And be with frailer things forgot. 
TIE POETKY OF FLOWERS.

Not thus with thee in that dim day, When, like the breath of flowers, Thy spirit leaves its vase of clay,

For love in those lone hours, Shall treasure up thy gentle worth. And warn remembrance call it forth,

And in a brighter, purer sphere,

Beyond the sunless tombThe virtues, that have charmed us here,

In fadeless life shall bloom;

And win from faith the fervid prayer, To meet thy sainted spirit there.

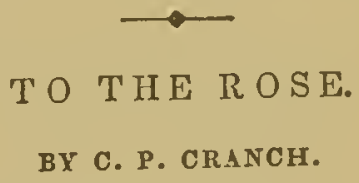

DEA flower of heaven and love! Thou gloriou thing

That lookest out the garden nooks among: Rose, that art ever fair and ever young; Was it some angel or invisible wing Hovered around thy fragrant sleep, to fling His glowing mantlle of warm sunset hues O'er thy unfolding petals, wet with dews Such as the flower-fays to Titania bring? $\mathrm{O}$ flower of thousand memories and dreams, That take the heart witl faintness, while we gazo 
On the rich depths of thy inwoven maze; From thc green banks of Fden's blesscd streams I drcam'd thee brought, of brighter days to tell, Long pass'd, but promised yet with us to dwell.

\section{BRING FLOWERS.}

MRS. HEMANS.

Bring flowers, young flowers, for the festal board. To wreathe the cup ere the wine is pour'd;

Bring flowers! thcy are springing in wood and vale,

'Their breath floats out on the southern gale, And the touch of the sunbeam hath waked the rose,

To deck the hall where the bright wine flows.

Bring flowers to strew in the conqueror's pathHe hath shaken thrones with his stormy wrath' He comes with the spoils of nations back, The vines he crush'd in his chariot's track, The turf looks red where he won the dayBring flowers to die in the conqueror's way !

Bring flowers to the captive's lonely cell, They have tales of the joyous woods to tell; Of the free blue streams, and the glowing sky, And the bright world shut from his languid eye: 
Thuy will bear him a thought of the sunny hours, And a dream of his youth-bring him flowers, wild flowers.

Bring flowers, fresh flowers, for the bride to wear!

They were born to blush in her shinıng hair. She is leaving the home of her childhood's mirth, She hath bid farewell to her father's hearth.

Her place is now by another's side-

Bring flowers for the locks of the fair young bride.

Bring flowers, pale flowers, o'er the bier to shed, A crown for the brow of the early dead!

For this through its leaves hath the wild rose burst,

For this in the woods was the violet nursed!

Though they smile in vain for what once was ours, They are love's last gift-bring ye flowers, pale flowers !-

Bring flowers to the shrine where we kneel in prayer,

They are Nature's offering, their place is there!

They speak of hope to the fainting heart,

With a voice of promise they come and part,

They sleep in dust through the wintry hours,

They break forth in glory-bring flowers, brigh flcwers! 


\section{THE POETRY OF FLUWERS.}

\section{TRANSPLANTED FLO WERS.}

BY E. ELLIOTT.

$Y_{E}$ living gems of cold and fragrant fire!

Die ye for ever, when ye die, ye flowers?

Take ye, when in your beauty ye expire, An everlasting farewell of your bowers?

No more to listen for the wooing air,

And song-brought morn, the cloud-tinged wood lands o'er!

No more to June's soft lip your breasts to bare, And drink fond evening's dewy breath no more! Soon fades the sweetest, first the fairest dies, For frail and fair are sisters; but the heart, Fill'd with deep love, death's power to kill denies. And sobs e'en o'er the dead, "We cannot part!" Have I not seen thee, Wild Rose, in my dreams ? Like a pure spirit-beauteous as the skies, When the clear blue is brighest, and the streams Dance down the hills, reflecting the rich dyes Of morning clouds, and cistus woodbine-twinedDidst thou not wake me from a dream of death? Yea, and thy voice was sweeter than the wind When it inhales the love-sick violet's breath, Bending it down with kisses, where the bee Hums over golden gorse, and sunny broum, Soul of the $R$ )se' What saidst thou then to me? 
"We meet," thou said'st, "Inough sever'd by the tomb:

Lo, brother, this is heav'n! And thus the just stall bloom."

\section{BLESSED BE GOD FOR FL.OWERS.}

Huggested by seeing my youngest child asleep, with wild Flowers grasped in its hand.

BY MRS. CHARLES TIESLEX.

BLESSED be God for flowers!

For the bright, gentle, holy thoughts, that breatiso From out their odorous beauty, like a wreath

Of sunshine on life's hours!

Lightly upon thine eye

Hath fallen the noon-tide sleep, my joyous bird : And through thy parted lips the breath, scarce heard,

Comes like a summer sigh.

One rosy hand is thrown

Beneath thy rosier cheek: the other holds

A group of sweet field-flowers, whose bloom unfolds

A freshness like thine own. 
48 THE POETRY OF FLCWERS.

Around the fragrant prize, With eager grasp thy little fingers olose : What are the dreams that haunt thy soft reposo I

What radiance greets thine eyes?

For thou art smiling still;

Art thou yet wandering in the quiet woods, Plucking th' expanded cups and bursting buds,

At thine urfetter'd will ?

Or does some prophet voice Murmuring amidst thy dreams, instructive say, "Prize well these flowers, for thou, beyond to-day,

Shalt in their spells rejoice!"

$\mathrm{Yes}$ ! thou wilt learn their power, When, cherish'd not as now, thou stand'st alone, Compass'd by sweetly saddening memories, thrown

Round thee by leaf or flower!

'Twill come! as seasons come, The empire of the flowers, when these shall raiso Round thee once more the forms of other days,

Warm with the light of home !

Shapes thou no more may'st see; The houseliold hearth, the heart-enlisted prajer 


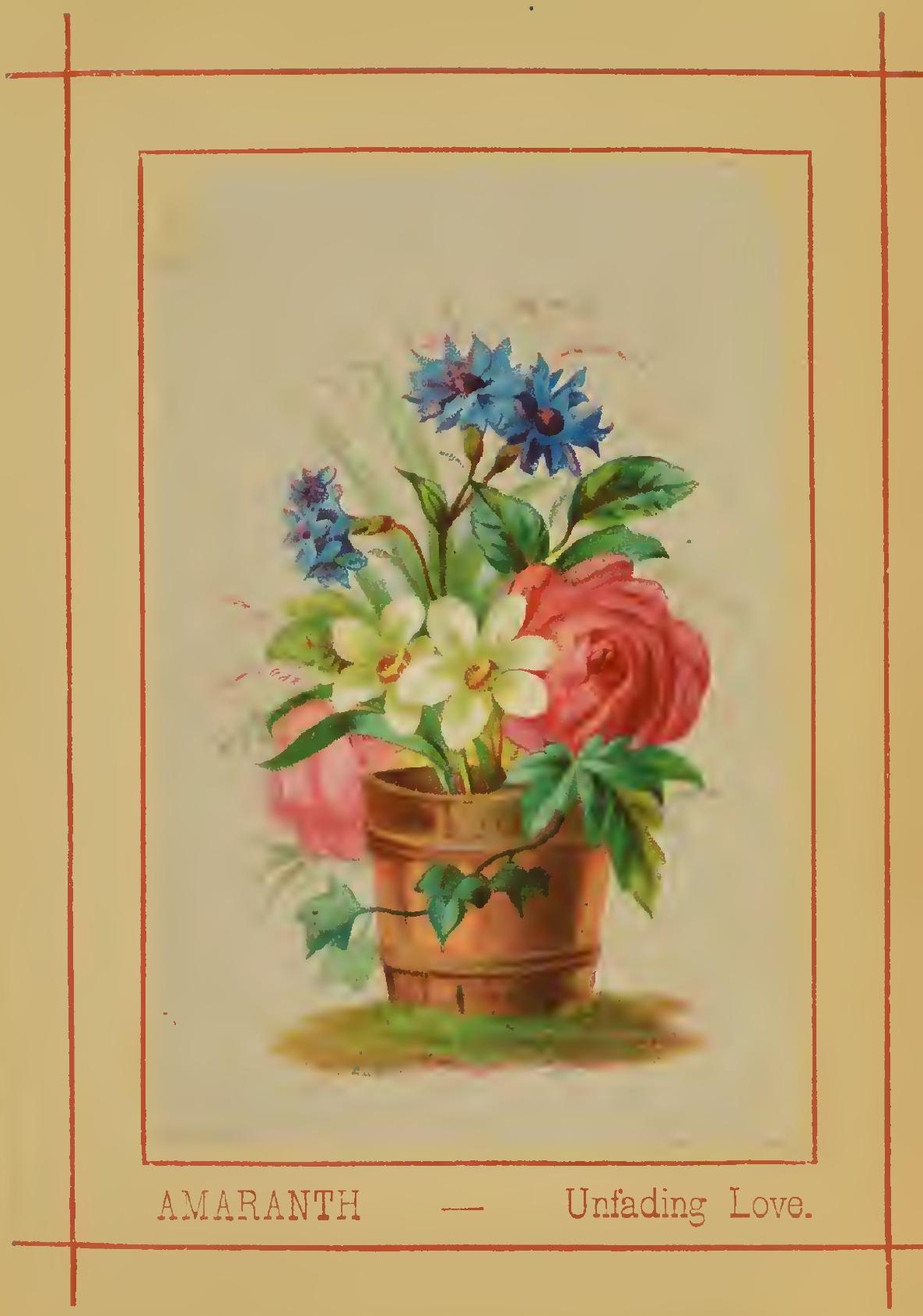



All thou hast loved, and lost, end treasured there. Where thy best thouglits must be!

Ay, prize them well, my child-

The bright, young blooming things that never die-

Pointing our hopes to happier worlds, that ho Far o'er this earthly wild !

\section{TO THE BRAMBLE FLOWER.}

\section{BY E. ELLIOTT.}

Thx fruit full-well the schoolboy knows, Wild bramble of the brake!

So, put thou forth thy small white rose;

I love it for his sake

Though woodbines flaunt and roses glow

$U^{\prime}$ er all the fragrant bowers,

Thou need'st not be ashamed to show

Thy satin-threaded flowers;

For dull the cye, the heart is dull

'That cannot fcel how fair,

A mid all beauty, bcautiful

Thy tender blossoms are !

How delicate thy gauzy frill!

How rich thy branchy stem!

How soft thy voice, when woods are still,

And thou sing'st hymns to them : 
While silent showers are falling siow And, 'mid the general hush,

A sweet ail lifts the little bougl,

Lone whispering through the bush!

The primrose to the grave is gone;

The hawthorn flower is dead;

The violet by the moss'd gray stone

Hath laid her weary head;

But thou, wild bramble ! back dost bring,

In all their beauteous power,

'The fresh green days of life's fair spring,

And boyhood's blossomy hour.

Scorn' $d$ bramble of the brake! once moro

'Thou bidd'st me be a boy,

To gad with thee the woodland's c'es

In freedom and in joy.

\section{CHILDREN OF THE SUN'S FIRST} GLANCING.

\section{FROM SCHILLER.}

CHILDREN of the sun's first glancing, Flowers that deck the bc untoous eartls;

Ioy and mirth are round yo dancing, Nature smiled upon your birth ;

Light hath veined your petals tender, And with hues of matchless splendour 
Flora paints each dewy bell. But lament, ye sweet spring bloss oms, Soul hath never thrilled your bosoms, All in cheerless night ye divell.

Nightingale and lark are singing Many a lay of love to you:

In your chaliced blossoms swinging, Tiny sylphs their sylphids woo:

Deep within the painted bower Of a soft and perfumed flower, Venus once did fall asleep : But no pulse of passion darted Through your breast, by her impartedChildren of the morning, weep.

When my mother's harsh rejection Bids me cease my love to speak, Pledges of a true affection, When your gentle aid I seek, Then by every voiceless token, Hope, anci faith unchanged, are spoken, And by you my bosom grieves: Love himself among you stealeth And his awful form concealeth, Shut within your folding leaves. 


\section{IAANGUAGE OF FLOWERS.}

BY H. W. LONGFELLOW.

Si AKE full well, in language quaint and clden, One who dwelleth by the castled Rhine, When he called the flowers so blue and golden Stars, that in earth's firmament do shine.

Stars they are, wherein we read our listory, As astrologers and seers of eld;

Yet not wrapp'd about with awful mystery, Like the burning stars, which they beheld.

Wondrous truths, and manifold as wondrous, God hath written in those stars above; But not less in the bright flowerets under us Stands the revelation of his love.

Bright and glorious is that revelation, Written all over this great world of ours; Making evident our own creation, In these stars of earth, - these golden flowers

And the Poet, faithful and far-seein $\bar{b}$, Sees alike in stars and flowers, a part of the self-same, universal Being, Whicl is throbbirg in his brairs and heart; 
Gorgeous floworets in the sunlight shir.sng, Blossoms flaunting in the eye of day, Tremulous leaves, with soft and silver lining, Buds that open only to decay;

Brilliant hopes, all woven in gorgeous tissues, Flaunting gaily in the golden light ;

Large desires, with most uncertain issues, Tender wishes. blossoming at night!

These in flowers and men are more than seeming Workings are they of the self-same powers, Which the poet, in no idle drcaming, Seeth in himself and in the flowers.

Every where about us are they glowing, Some like stars, to tell us Spring is born; Others, their blue eyes with tears o'erflowing; Stand like Ruth amid the golden corn;

Not alone in Spring's armorial bearing, And in Summer's green-emblazoned field, But in arms of brave old Autumn's wearing, In the centre of his brazen shield;

Not alone in meadows and green alleys, On the mountain-top, and by the brink Of sequestered pools in woodland valleys, Where the slaves of Nature stoop to drinks 
Not alone in her vast dome of glory, Not on graves of bird and beast alone, But in old cathedrals, high and hoary, On the tombs of heroes, carved in stons;

In the cottage of the rudest peasant, In ancestral homes, whose crumbling towers, Speaking of the Past unto the Present, Tell us of the ancient Games of Flowers;

In all places, then, and in all seasons, Flowers expand their light and soul-like winga Teaching us, by most persuasive reasons, How akin they are to human things.

And with child-like, credulous affection, We behold their tender buds expand :Emblems of our own great resurrection, Emblems of the bright and better land. 
FIE POETRY OF FLOWERS.

\section{THE STAR AND THE WATER-LU Y.}

BY O. W. HOIMES.

The Sun stepp'd down from his golden throne, And lay in the silent sea,

And the Lily had folded her satin lcaves,

For a sleepy thing was she;

What is the Lily dreaming of ?

Why crisp the waters blue?

See, see, she is lifting her varnish'd lid!

Her white leaves are glistening through!

'The Rose is cooling his burning cheek

In the lap of the breathless tide;

The Lily hath sisters fresh and fair,

That would lie by the Rose's side;

IIe would love her better than all the rest

And he would be fond and true;

But the Lily unfolded her weary lids,

And look'd at the sky so blue.

Remember, remember, thou silly one,

How fast will thy summer glide,

And wilt thou wither a virgin pale,

Or flourish a blooming bride?

"O, the Rose is old, and thorny, and cold,

And he lives on earth," said she;

"But the Star is fair and he lives in the air,

And he shall my bridegroom be." 
But what if the stormy cloud should come, And ruffle the silver sea?

Would he turn his eye from the distant stsy,

To smile on a thing like thee?

O, no! fair Lily, he will not send

One ray from his far-off throne;

The winds shall blow and the waves shall flow

And thou wilt be left alone.

There is not a leaf on the mountain-top,

Nor a drop of evening dew,

Nor a golden sand on the sparkling shore,

Nor a pearl in the waters blue,

That he has not cheer'd with his fickle smile

And warm'd with his faithless beam, $\rightarrow$ -

And will he be true to a pallid flower,

That floats on the quiet stream?

Alas, for the Lily! she would not heed,

But turn'd to the skies afar,

And bared her breast to the trembling ray

That shot from the rising star;

The cloud came over the darken'd sky,

And over the waters wide;

She look'd in vain through the beating rain,

And sank in the stormy tido. 
FLOWERS FOR THE HEART.

BY E. ELLIOTT.

FLowers! winter flowers ! - the child is dead The mother cannot speak :

$\mathbf{O}$ softly couch his little head, Or Mary's heart will break !

Amid those curls of flaxen hair This pale pink riband twine, And on the little bosom there Place this wan lock of mine.

How like a form in cold white stone, 'The coffin'd infant lies!

Look, Mother, on thy littlo one ! And tears will fill thine eyes.

She cannot weep, more faint she grows More deadly pale and still: Flowers ! oh, a flower ! a winter rose, That tiny hand to fill.

Go, search the fields ! the lichen wot Bends o'er th' unfailing well; Beneath the furrow lingers yet

The scarlst pimpernel. 
Peeps not a snowdrop in the bower, Where never froze tha spring?

A daisy? Ah! bring childhood's flower! The half blown daisy bring!

Yes, lay the daisy's little head Beside the little cheek;

$O$ haste! the last of five is dead! The childless cannot speak !

\section{THE AMARANTH.}

Crowns inwove with Amaranth and gold, Immortal Amaranth, a flower, which once In Paradise, fast by the Tree of Life, Began to bloom ; but soon, for man's offence, To Heaven removed, where first it grew, thero grows

And flowers aloft, shading the Fount of Life, And where the River of Bliss, through midst of Heaven,

Rolls o'er Elysian flowers her amber stream; With these, that never fade, the spirits elect, Bind thrir resplendent locks. Milton 


\section{THE WALL-FLOWER}

BY D. M. MOIR.

The wall-flower-the wall-flower How beautiful it blooms!

It gleans above the ruin'd tower, Like sunlight over tombs;

It sheds a halo of repose

Around the wrecks of time;-

To beauty give the flaunting rose,

The wall-flower is sublime.

Flower of the solitary place!

Gray ruin's golden crown ?

Thou lendest melancholy grace

To haunts of old renown;

Thou mantlest o'er the battlement,

By strife or storm decay'd ;

And fillest up each envious rent

Time's canker-tooth hath made.

Whither hath fled the choral band

That fill'd the abbey's nave?

Yon dark sepulchral yew-trees str nd

O'er many a level grave;

In the belfry's crevices, the dove

Her young brood nurseth well,

Whilst thou, lone flower! dost shed anove

A sweet decaying smell. 
In the season of the tulip cup, When blossoms clothe the trees, How sweet to throw the lattice up, And scent thee on the breeze!

The Butterfly is then abroad, The bee is on the wing, And on the hawthorn by the road The linnets sit and sing.

Sweet wall-flower-sweet wall-flower' Thou conjurest up to me, Full many a soft and suniy hour Of boyhood's thoughtless glee; When joy from out the daises grew In woodland pastures green, And summer skies were far more blue Than since they e'er have been.

Now autumn's pensive voice is heard Amid the yellow bowers, The robin is the regal bird, And thou the queen of flowers? He sings on the laburnum trees, A mid the twilight dim, And Araby ne'er gave the breeze Such scents as thou to him.

Rich is the pink, the lily gay, The rose is summer's guest ; Bland are thy charms when these decas Of flowers, first, last, and best! 
THE FOETRY OF FLOWERS.

There may be gaudier on the bower, And statelier on the tree;

But wall-flower, loved wall-flower,

Thou art the flower for me!

\section{THE LAST ROSE OF SUMMER}

BY T. MOORE.

'Tis the last rose of summer

Left blooming alone,

All her lovely companions

Are faded and gone;

No flower of her kindred,

No rose-bud is nigh,

To reflect back her blushes

And give sigh for sigh.

I'll not leave thee, thou lone one

To pine on the stem;

Since the lovely are sleeping,

Go sleep thou with them.

Thus kindly I scatter

Thy leaves on the bed,

Where thy mates of the garden

Lie scentless ind dead.

So soon may I follow

When friendships decay,

And from love's shining circlo

The gems drop away: 
When true hearts lie wither'd

And fond ones are flown,

Oh! who would inhabit

This cold world alone?

THE RHODORA.

LINES O BEING ASKED, WHENCE IS THE FLOW I

BY RALPH WALDO EMERSON.

IN May, when sea-winds pierced our solitudes, I found the fresh Rhodora in the woods, Spreading its leafless blooms in a damp nook, To please the desert and the sluggish brook; The purple petals, fallen in the pool,

Made the black waters with their beauty gay;

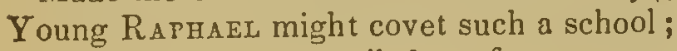
The lively show beguiled me from my way.

Rhodora! if the sages ask thee why This charm is wasted on the marsh and sky, Dear, tell them, that if eyes were made for seeing Then beauty is its own excuse for being.

Why, thou wert there, $O$, rival of the rose!

I never thought to ask, I never knew.

But in my simple ignorance suppose

The selfsame Power thai brought me there, brought you. 


\title{
THE EVENING PRIMROSE
}

\author{
BY G. LANGHORNE.
}

ThERE are tliat love tile shades of life, And shun the splendid walks of fame There are that hold it rueful strife

'To risk Ambition's losing game;

That far from envy's lurid eye

The fairest fruits of genius rear,

Conten $i$ to see them bloom and die

In friendship's small but kindly spher $\mathrm{\theta}$.

Than vainer flowers, though sweeter far, The Evening Primrose shuns the day;

Blooms only to the western star,

And loves its solitary ray.

In Eden's vale an aged hind,

At the dim's twilight's closing hour,

On his time-smoothed staff reclined,

With wonder view'd the opening flowe.

"Ill-fated flower, at eve to blow,"

(In pity's simple thought he cries,)

"Thy bosom must not feel the glow

Of splendid suns, o: smiling skies. 
"Nor thee the vagrants of the field, The hamlet's little train beliold;

Their eyes to sweet oppression yield,

When thine the falling shades unfold.

a Nor thee the hasty shepherd heeds, When love has fill'd his heart with cares:

For flowers he rifles all the meads; For walking flowers-but thine forbeara

Ah! waste no more that beauteous bloom, On night's chill shade that fragrant breats,

Let smiling suns those gems illume?

Fair flower! to live unseen is death !"

Soft as the voice of vernal gales

That o'er the bending meadows blow,

Or streams that steal through even vales,

And murmur that they move so slow.

Deep in her unfrequented bower,

Sweet Philomela pour'd her strain ;

'The bird of eve approved her flower,

And answer'd thus the anxious swain :-

"Live unseen !

By moonlight shades, in valleys green,

Lovely flower, we'll live uriseen.

Of our pleasures deem not lightly,

Laughing day may look more sprightly 
But I love the modest mien, Still I love the modest mien

of gentle evening fair, and her star-train'd quece

"Didst thou, shepherd, never find Pleasure is of pensive kind? Has thy cottage never known That she loves to dwell alone? Dost thou not at evening hour Feel some soft and secret poiver Gliding o'er thy yielding mind, Leave sweet serenity behind,

- While, all disarm'd, the cares of day Steal through the falling gloom awav 1 Love to think thy lot was laid In this undistinguish'd shade. Far from the world's infectious view Thy little virtues safely blew. Go, and in day's more dangerous how Guard thy emblematic flower." 


\section{THE WINTER NOSEGAY.}

\section{BY TVILLIAM COWPER.}

W нат nature, alas! has denied

To the delicate growth of our isle, Art has in a measure supplied,

And winter is deck'd with a smile. See, Mary, what beauties I bring

From the shelter of that sunry shed, Where the flowers have the charms of the spring

Though abroad they are frozen and dead.

- Tis a bower of Arcadian sweets, Where Flora is still in her prime,

\section{A fortress to which she retreats}

From the cruel assaults of the clime. While earth wears a mantle of snow,

These pinks are as fresh and as gay As the fairest and sweetest that blow

On the beautiful bosom of May.

Soe how they have safely survived The powers of a sky so severe;

Such Mary's true love, that has lived

'Through many a turbulent year.

The charms of the late-blowing roso

Seem gracen with a livelier hue,

And the winter of sorrow best shows

The tzuth of a friend such as you. 
THE POETRY GF FLOWERS.

\section{THE AL MOND.TREE}

\section{BY MISS IANDON.}

fietering and falling,

Where is the bloom

Of yon fair Almond-tree?

It is sunk in the tomb.

Its tomb wheresoever

The wind may have borne

The leaves and the blossoms

Its roughness has torn.

Some there are floating

On yon fountain's breast, -

Some line the moss

Of the nightingale's nest, -

Some are just strewn

U'er the green grass below, And there they lie stainless

As winter's first snow.

Yesterday, on the boughs

They hung scented and fair ;

To-day they are scatter'd

The breeze best knows wher. 
To-morrow those leaves

Will be scentless and dead,

For the kind to lament

And the careless to tread.

And is it not thus

With each hope of the heart

With all its best feelings ?-

Thus will they depart :

They'll go forth to the world On the wings of the air, Rejoicing and hoping ;

But what will be there ?-

False lights to deceive,

False friends to delude,

Till the heart in its sorrow's

Left only to brood.

Over feelings crush'd, chill'd, Sweet hopes ever flown;

Like that tree when its green lesres

And blossoms are gone. 
TPQ POETRI OF FLOWERS.

\section{THE LILY.}

\section{BY JAMES G. PERCIVAL.}

1 HAD foun 1 out a sweet green spot Where a lily was blooming fair ;

The din of the city disturb'd it not; But the spirit that shades the quiet cot With its wings of love was there.

I found that lily's bloom

When the day was dark and chill:

It smiled like a star in a misty gloom,

And it sent abroad a sweet perfume,

Which is floating around me still.

I sat by the lily's bell,

And watch'd it many a day :-

The leaves, that rose in a flowing swell, Grew faint and dim, then droop'd and fell, And the flower had flown away.

I look'd where the leaves were laid, In withering paleness, by ;

And as gloomy thcughts stole on me, said, 'There's many a sweet and blooming maid Who will soon as dimly die. 


\section{THE MARY G OLD.}

\section{BY G. WITHERS.}

WHEN with a serious musing, I behold The grateful and obsequious Marygold, How duly, every morning, she displays Her open breast when Phœbus spreads his raya . How she observes him in his daily walk, Still bending tow'rds him her small slender stalk; How, when he down declines, she droops and mourns,

Bedew'd as 'twere with tears, till he returns; And how she veils her flowcrs when he is gone, As if she scorned to be look'd upon By an inferior eye ; or did contemn To wait upun a meaner light than him: When this I meditate, methinks the flowers Have spirits far more genero is than ours, And give us fair cxamples to despise The servile fawnings and idolatries Wherewith we court thesc earthly things below Which merit not the service we bestow, But O, my God! though grovelling I appear Upon the ground, and have a rooting here Which hales me downward, yet in my desire To that which is above me I aspire, And all my best affections I profess To IIim tha: is the Sun of Righteousneas 
THE POEIRY CF FI,OWERS.

Oh ! reep the morning of his incarnation, The burning noon-tide of his bitter passion, The night of his descending, and the height Of his ascension,-ever in my sight, That, imitating him in what 1 may, I never follow an inferior way.

\section{THE LILY.}

BY SAMUEL TAYLOR COLERIDGE.

THE stream with languid murmur creeps In Lumin's flow'ry vale :

Beneath the dew the lily weeps, Slow waving to the gale.

". Cease, restless gale!" it seems to say' "Nor wake me with thy sighing!

The honours of rily vernal day On rapid wings are flying.

"To-morrow shall the traveller come Who late boheld me blooming; His searching eye shall vainly roam The dreary vale $a$ : Lumin.' 


\section{CUPID AND THE DIAL.}

O.ve day, young frolic Cupid tried

To scatter roses o'er the hours,

And on the dial's face to hide

The course of time with many flowers.

By chance, his rosy wreat'ns had wound Upon the hands, and forced them on; And when he look'd again, he found The hours had pass' $d$, the time was done.

'Alas!" said love, and dropp'd his flowere "I've lost my time in idle play;

The sweeter I would make the hours, The quicker they are pass'd away.'

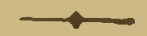

\section{THE CLOSED CONVOLVULLS.}

As hour ago, and sunny beams

Were glancing o'er each airy bell ; And thou wert drinking in those gleams, Like beauty listening love's farewell.

And now with folded drooping leaves, Thot seemest for that light to mourn, Like unto one who fondly grieves

Tho hours that stew some friend's return. 
THE POETKY OF FLOWERS.

We cannot trace the hidden power

Which folds thine azure petals up:

When evening shadows dimly lower,

And dew-drops gem each floweret's cup

Methinks I should not wish to be

Like thee, a votary of the sun,

To bask beneath his beams, yet flee

Whene'er his brilliant race is run.

$O$ dearer far the silent night,

And lovelier far the star-lit slsy,

Than gaudy day with sunbeams bright,

And loud with nature's minstrelsy.

The night-bird's song is not for thee,

The beautiful, the silver moon,

The holy calm o'er flowers and tree;

The stillness-nature's dearest boon.

Thou art a reveller of day,

A fair, rejoicing child of light ;

Glad, while the sunbeams o'er thee play,

But drooping in the quiet night.

Like unto those who freely spend

Their kindness in our happier hours

But should affliction want a friend,

'T'hey prove the sun's adoxing flower. 


\section{HUMAN FLOWERS}

\section{BY WILIIAM HOWITT.}

SweEt Lucy has chosen the lily, as pale, And as lowly as she, still the pride of the vale: Ań emblem more fitting, so fair and retired, Heart could not have chosen, nor fancy desired.

And Ellen, gay Ellen, a symbol as true, In the hare-bell has found, and its delicate blue. For ever the blossoms are frcsh in her eyes, As dewy, as sweet, and more soft than the skies.

And Jane, in her thoughtfuiness, conscious of power,

Has gazed in her fervour on many a flower:

Has chosen, rejected, then many combined

To blazon her graces of person and mind.

Whilst Isabel's face, like the dawn, in one flushFar need she nct wander to bank and to bush; Well the tint of her cheek the young Isabel knows,

For the blassom of health is the beautiful rose.

And Mary, the pensive, who loves in the dusk Of the gardens to muse, when the air is all musk; Will leave all its beauties, and many they are, To gaze, meek in thought on the jessamine star. 
And Kate, the light butterfly Kate, evcr gay :

Will choose the first blossom that comes in way:

The cistus will please her a moment, and then Away will she flutter, and settle again.

But Julia for me, with her heart in her eyes, The child of the summer, too warm to be wise: Is the passion-flower near her, with tendrils close curled,

She can smile whilst she suffers; 'tis hers for the world.

All are lovely, all blossom of heart and of mind All true to their natures, as Nature design'd; To cheer and to solace, to strengthen, caress, And with love that can die not to buoy and to bless.

With gentleness might, and with weakness, what grace!

Revelations from Heaven in form and on facc;

Like the bow in the cloud, like the flower on the sod,

They ascend and descend in my dreams as from God. 


\section{THE IIYING BOY TO THE SLOE BLOSSOM.}

\section{BY E. ELLIOTT.}

BEFORE thy leaves thou com'st once more,

White blossom of the sloe!

Thy leaves will come as heretofore; But this poor heart, its troubles o'er, Will then lie low.

A month at least before thy time

Thou com'st, pale flower, to me;

For well thou know'st the frosty rime IVill blast me ere my vernal prime, No more to be.

Why here in winter? No storm lours O'er natire's silent shroud!

But blithe larks meet the sunny shower, High o'er the doom'd untimelv flowers In beauty bow'd.

Sweet violets in the budding grove

Peep where the glad waves run; The wren below, the thrush above, Of bright to-morrow's joy and love Sing to the sun. 
And where the rose-leaf, ever bold,

Hears bees chant hymns to God,

The breeze-bow'd palm, moss'd o'er with gold,

Smiles o'er the well in summer cold,

And dasied sod.

But thou, pale blossom, thou art come,

And flowers in winter blow,

To tell me that the worm makes room

For me, her brother, in the tomb,

And thinks me slow.

For as the rainbow of the dawn

Foretells an eve of tears,

A sunbeam on the sadden'd lawn

I smile, and weep to be withdrawn

In early years.

Thy leaves will come! but songful spring

Will see no leaf of mine ;

Her bells will ring, her bridemaids sing,

When my young leaves are withering

Where no suns shine.

Oh, might I breathe morn's dewy breath

When June's sweet Sabhaths chime!

But, thine before my time, oh, death!

I go where no flow'r blossometh,

Before my time. 
Even as the blushes of the morn

Vanish, and long ere noon

The dew-drop dieth on the thorn,

So fair I bloom'd; and was I born

To die as soon?

To love my mother, and to die-

To perish in my bloom!

Is this my sad, brief history !-

A tear dropp'd from a mother's eyo

Into the tomb.

He lived and loved-wil! sorrow say-

By early sorrows tried;

He smiled, he sigh'd, he pass'd away .

His life was but an April day,-

He loved, and died!

My mother smiles, then turns away,

But turns away to weep:

They whisper round me-what they as

[ need not hear, for in the clay

I soon must sleep.

0 , love is sorrow ! sad It is

To be both tried and true;

I ever trembled in my bliss :

Now there are farewells in a kiøs, -

They sigh adieu. 
But woodbines flaunt when blue bells fade, Where Don reflects the skies;

And many a youth in Shirecliffs' shade Will ramble where my boyhood play'd;

Though Alfred dies.

Then panting woods the breeze will feel And bowers, as heretofore, Beneath their load of roses reel :

But I through woodbine lanes shall steal No more, no mors.

Well, lay me by my brother's side, Where late we stood and wept; For I was stricken when he dioses I folt the arrow as he sigh'd

His last, ans nort, 


\title{
SONGS AND CHORUS OF THE
} FLOWERS.

\author{
BY LITGH HONT.
}

\section{ROSES.}

WE are blushing roses,

Bending with our fulness,

'Midst our close-capp'd sister bud.

Warming the green coolness.

\section{Whatsoe'er of beauty}

Yearns and yet reposes,

Blush, and bosom, and sweet breath,

Took a shape in roses.

Hold one of us lightly,- .

See from what a slender

Stalk we bower in heavy blooms, And roundness rich and tender

Know you not our only

Rival flower, - the human

Loveliest weight on lightest foot,

JoY-abiudant woman 


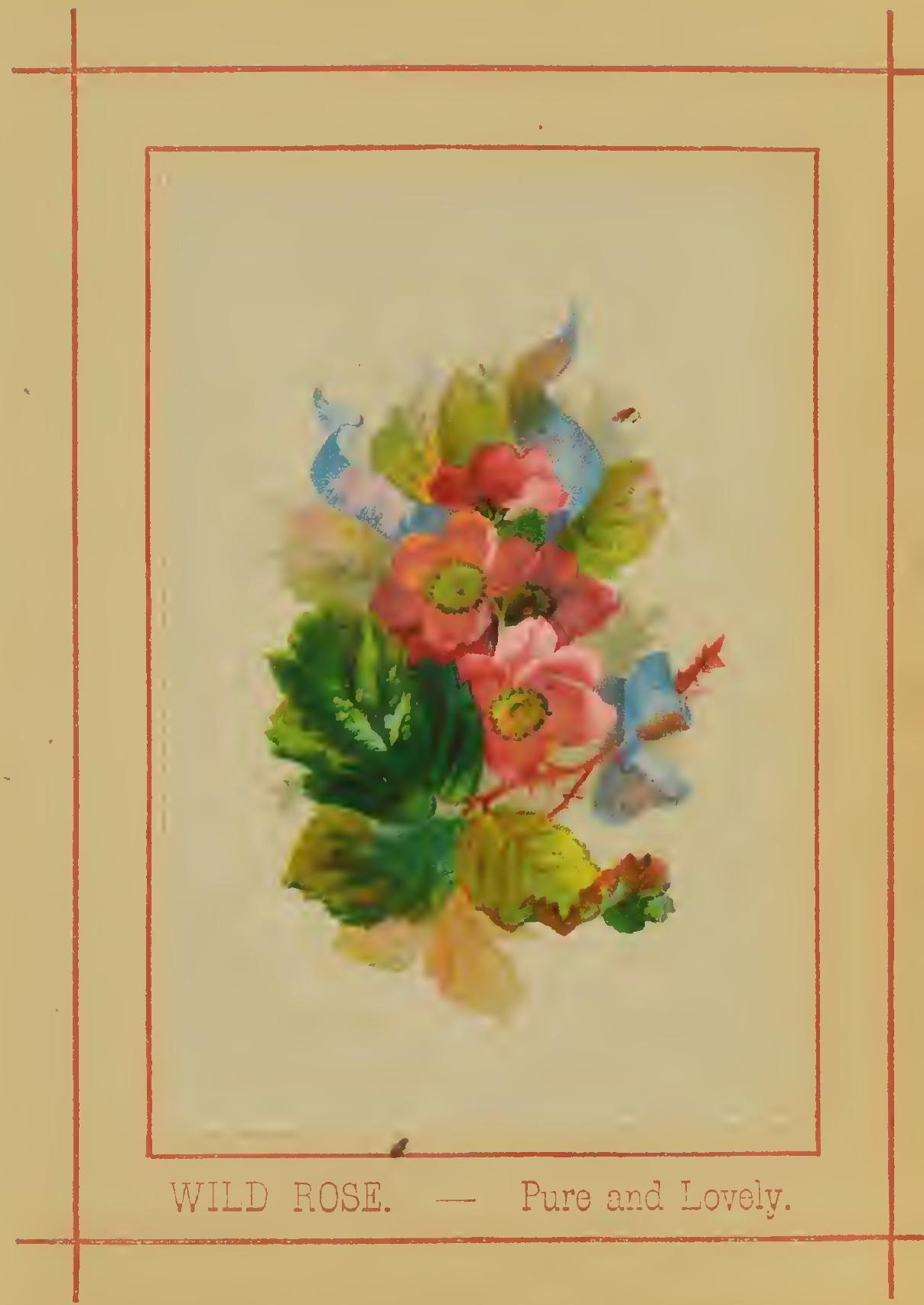



TIE POETRY OF FLOWERS.

LILIES.

WE are lilies fair,

'I'he flower of virgin light;

Nature held us forth, and said,

"Lo! my thoughts of white"

Ever since then, angels

Hold us in their hands;

You may see them where they take

In pictures their sweet stands.

Like the garden's angels

Also do we seem;

And not the less for being crown'd

With a golden dream.

Could you see around us

The enamour'd air,

You would see it pale with bliss

To hold a thing so fair.

\section{IOFPIES.}

$W_{\mathbf{E}}$ are slumbering poppies,

Lords of Lethe downs,

Some awake, and some asleep,

Sleeping in our crowns.

What perchance our dreans mav know,

Let our serious beauty show.

6 
Central depth of purple,

Leaves more bright than rose,-

Who shall tell what brightest thoughs

Out of darkest grows?

Who, through what funereal pain,

Souls to love and peace attain?

Visions aye are on us,

Unto eyes of power;

Pluto's always-setting sun,

And Proserpine's bower:

There, like bees, the pale souls come

For our drink, with drowsy hum.

Taste, ye mortals, also ;

Milky-hearted, we ;-

Taste, but with a reverent care,

Active-patient be.

Too much gladness brings to gloom

Those who on the gods presume.

chorus.

WE are the sweet flowers,

Born of sunny showers,

Think, whene'er you see us, what our beaut saith ;i

Utterance, mute and bright,

Of some unknown delight,

We fill the air with pleasure, by our simple breath : 
IHE POETRY OF FLOWERS.

All who see us love us, -

We hefit all places:

¿nto sorrow we give smiles, - and unto graces, races

Mark our ways, how noiseless

All, and sweetly voiceless,

Though the March-winds pipe, to make our passage clear;

Not a whisper tells

Where our small seed dwells,

Nor is known the moment green, when our tips appear.

We thread the earth in silence,

In silence build our bowers, -

And leaf by leaf in silence show, till we laugh a-top, sweet flowers.

The dear lumpish baby,

Humming with the May-bee,

Hails us with his bright star, stumbling througb the grass;

The honey-dropping moon,

On a night in June,

Kisses our pale pathway leaves, that felt the bridegroom pass.

Age, the wither'd clinger,

On us mutely gazes,

And wraps the thought of his last bed in his childhood's daisies. 
84 IHE POETRY OF FLOWERS.

See (and scorn all duller

Taste) how heav'n loves colour;

How great Nature, clearly, joys in red and green;-

What sweet thoughts she thinks

Of violets and pinks,

And a thousand flushing hues, made solely to be seen :

See her whitest lilies

Chill the silver showers,

And what a red mouth is her rnse, the woman of her flowers.

Usclessness divinest,

Of a use the finest,

Painteth us, the teachers of the end of use;

Travallers, weary eyed,

Bless us, far and wide;

Unto sick and prison'd thoughts we give sudden truce :

Not a poor town window

Loves its sickliest planting,

But its wall speaks loftier truth than Babylonian vaunting.

Sagest yet the uses,

Mix'd with our swect juices,

Whether man or May-fly, profit of tne balm,

As fair fingers heal'd

Knights from the old on field 
TIIE POETRY OF FLOWERS.

We hold cups of mightiest force to give the wild est calm.

Ev'r the terror, poison,

Hath its plea for blooming;

Life it gives to reverent lips, though death to the presuming.

And oh! our sweet soul-taker,

That thief, the honey maker,

What a house hath he, by the thymy glen ?

In his talking rooms

How the feasting fumes,

Till the gold cups overflow to the mouths of men .

The butterflies come aping

Those fine thieves of ours,

And flutter round our rifled tops, like ticklea flowers with flowers.

See those tops, how beauteous !

What fair service duteous

Round some idol waits, as on their lord the Nine

Elfin court 'twould seem ;

And taught, perchance, that dreum

Which the old Greek mountain dreamt, upon nights divine.

To expound such wonder

Human speech avails not;

let there dies no prorest weed, tha: such a glory exhales not. 
86 THE POETRY OF ZLOWERS.

Think of all these treasures

Matchless works and pleasures

Every one a marvel, more than thouglit can ay

Then think in what bright showers

We thicken fields and bowers,

And with what heaps of sweetness half stifle wanton May:

Think of the mossy forests

By the bee-birds haunted,

- na all those Amazonian plains, lone lying enchanted.

Trees themselves are ours;

Fruits are born of flowers;

Peach, and roughest nut, were blossoms in the spring :

The lusty bee knows well

The news, and comes pell-mell,

And dances in the gloomy thicks with darksome antheming.

Beneath the very burthen

Of planet-pressing ocean,

We wash our smiling cheeks in peace,,- a thought for meek devotion.

Tears of Phœbus.-missings

Of Cytherea's kissings,

Have in us been found, and wise men find them still; 
Drooping grace unfurls

Still Hyacinthus' curls,

And Narcissus loves himself in the selfish till:

Thy red lip, Adonis,

Still is wet with morning;

And the step, that bled for thee, the rosy oriet adorning,

O ! true things are fables,

Fit for sagest tables,

And the flowers are true things,-yet no fubles they ;

Fables were not more

Bright, nor loved of yore,-

Yet they grew not, like the flowers, by every old pathway:

Grossest hand can test us ;

Fools may prize us never:-

Yet we rise, and rise, and rise,-marvels sweet for ever.

Who shall say, that flowers

Dress not heaven's own bowers?

Whs its love, without us, can fancy-or sweet floor?

Who shall even dare

To say, we sprang not tliere,-

And came not down that Love might bring no piece of heaven the more? 
THE POETRY OF FI OWERS,

0 ! pray believe that angels

From those blue dominions,

Brought us in their white laps down, 'twixt theis golden pinions.

\section{$\longrightarrow$ \\ THE NARCISSUS. \\ BY JOHY KEATS.}

WHAT first inspired a bard of old to sing

Narcissus pining o'er the untainted spring?

In some delicious ramble he had found

A little space, with boughs all woven round;

And in the midst of all a clearer pool

Than e'er reflected in its pleasant cool

The blue sky, here and there serenely peeping,

Through tendril wreaths fantastically creeping.

And on the bank a lonely flower he spied,

A meek and forlorn flower, with nought of pride,

Drooping its beauty o'er the watery clearness,

To woo its own sad image into nearness :

Deaf to light Zephyrus it would not move,

But still would seem to droop, to pine, to love.

So while the poet stood in this sweet spot,

Some fainter gleamings o'er his fancy shot;

Nor was it long ere he had told the tale

Df young Narsissus, and sad Eiho's vale. 


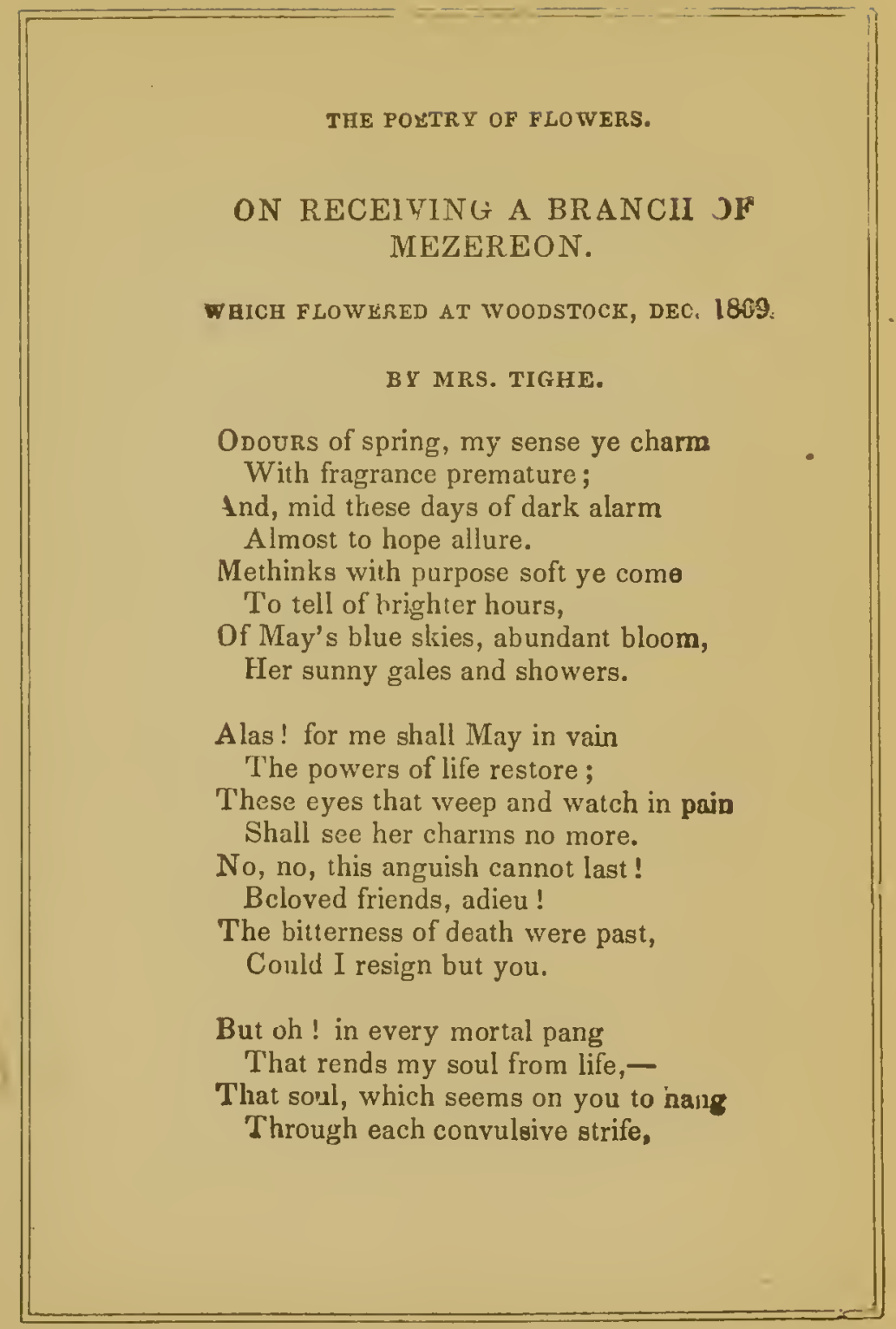


Even now, with agonizing grasp Of terror and regret,

To all in life its love would clasp, Clings close and closer yet.

Yet, why, immortal, vital spark! Thus mortally opprest?

Look up, my soul, through prospects dark And bid thy terrors rest;

Forget, forego thy earthly part, Thine heavenly being trust:

Ah, vain attempt! my coward heart Sitill shuddering clings to dust.

O ye ! who soothe the pangs of death With love's own patient care, Still, still retain this fleeting breath, Still pour the fervent prayer.

And ye, whose smile must greet my eye

No more, nor voice my ear,

Who breathe for me the tender sigh: And shed the pitying tear;

Whose kindness (though far, far removed)

My grateful thoughts perceive,

Pride of my life, esteem'd, beloved,

My last sad claim receive !

Oh! do not quite your friend forget,

Forget alone her faults;

And speak of her with fond regret

Who asks your lingering thoughto. 


\section{'THE LIT'TLE RED ROSE.}

\section{FROM GOETHE.}

A BOY caught sight of a rose in a bowerA little rose slily hiding

Among the boughs; $\mathrm{O}$ ! the rose was bright And young, and it glimmer'd like morning light, The urchin sought it with haste; 'twas a flower

A child indeed might take pride in-

A little rose, little rose, little red rose, Among the bushes hiding.

The wild boy shouted- "I'll pluck thee, rose,

Little rose vainly hiding

Among the boughs;" but the little rose spoke"I'll prick thee, and that will prove no joke;

Unhurt, O then will I mock thy woes,

Whilst thou thy folly art chiding."

Little rose, little rose, little red rose, Among the bushes hiding !

But the rude boy laid his hands on the flower, The little rose vainly hiding Among the boughs; $O$, the rose was caught, But it turned again, and pricked and fought, And left with its spoiler a smart from that hour

A pain for ever abiding ;

Little rose, little rose, little red rose, Among the bushes hiding ! 
THE VOICE OF THE FLOWER3.

BY MARY ANNE BROWNE.

BLossoms, that lowly bend, Shutting your leaves from evening's chilly dow While your rich odours heavily ascend,

The flitting winds to woo.

I walk at silent eve, When scarce a breath is in the garden bowers, And many a vision and wild fancy weave,

'Midst ye, ye lovely flowers;

Beneath the cool green boughs, And perfumed bells of the fresh blossom'd lino That stoop and gently touch my feverish brow Fresh in their summer prime;

Or in the mossy dell, Where the pale primrose trembles at a breath; Or where the lily, by the silent well,

Beholds her form beneath;

Or where the rich queen-rose

Bits, throned and blushing, 'midst her leaves and moss ;

Dr where the wind-flower, pale and fragilo, blows Or violets banks emboss. 
Here do I love to be, -

Nhe eye alone in passionate love to dwell

Jpon the loneliness and purity

Of every bud and bell.

Oh blessedness, to lie,

By the clear brook, where the long benuet dips!

To press the rose-bud in its purity

Unto the burning lips!

To lay the weary head

Upon the bank, with daisies all beset, Or with bared feet, at early dawn to tread

O'er mosses cool and wet?

And then to sit, at noon,

When bees are humming low, and birds are still, And drowsy is the faint uncertain tone

Of the swift woodland rill.

And dreams can then reveal

That, wordless though ye be, ye have a tone

A language and a power, that I may feel,

Thrilling my spirit lone.

Ye speak of Hope and Love,

Bright as your hues, and vague as your perfume; Df changeful, fragile thoughts, that brightly move Men's hearts amidst their gloom. 
34 TEE POETRY UF FLOWALE

Ye speak of human life, Its mystery-the beautiful and brief; Its sudden fading 'midst the tempest stric, Even as a delicate leaf.

And, more than all, ye speak Of might, and power, of mercy, of the One Eternal, who hath strew'd you fair and meek,

To glisten in the sun;

To gladden all the earth

With bright and beauteous emblems of his grace, That showers its gifts of uncomputed worth

In every clime and plece. 
TIE POETRY OF FLOWERS.

\section{WILD FLOWERS.}

\section{BY SHELLY.}

DRTAM'D that, as I wander'd by the way, Bare winter suddenly was changed to syring, And gentle odours led my steps astray, Mix'd with a sound of waters murmuring Along a shelving bank of turf, which lay Under a copse, and hardly dared to fling Its green arms round the bosom of the stream, But kiss'd it and then fled. as thon mightest in a drean.

There grew pied wind-flowers and violets, Daisies, those pearl'd Arcturi of the earth, The constellated flower that never sets;

Faint oxlips; tender blue-bells, at whose birth The sod scarce heaved; and that tall flower that wets

Its mother's face with heaven-collected tears, When the low wind, its playmate's voice, it hears.

And in the warm hedge grew lush eglantine,

Green cowbind and the moonlight-colour'd May,

And cherry blossoms, and white cups, whose wine

Was the bright dew yet drain'd not by the day; And wild roses, and ivy serpentine, 
With its dark buds and leaves, wandering astray, And flowers azure, black, and streak'd with gold; Fairer than any waken'd eyes behold.

And nearer to the river's trembling edge There grew broad flag-flowers, purple prankt with white,

And starry river buds among the sedge, And floating water-lilies, broad and bright, Which lit the oak that overhung the hedge

With moonlight beams of their own watery light ;

And bulrushes and reeds of such deep green As soothed the dazzled eye with sober sheen.

Methought that of these visionary flowers

I made a nosegay, bound in such a way That the same hues which in their natural bower

Were mingled or opposed, the like array Kept these imprison'd children of the hours

Within my hand, - and then, elate and gay, I hasten'd to the spot whence I had come, That I might there present it! - Oh! to whom I 


\section{CUPID INSPIRING PLANTS WITH} LOVE.

B Y D Y E R. sth

TrEming with Nature's lively hues, I bid thee welcome, genial Sprive. While fancy wakes her thousand lyres, And woods and vales responsive sing.

She comes; lo! WINTER scowls away; Harmonious forms start forth to view; Nymphs tripping light in circles gay, Deck'd in their robes of virgin hue.

Then I, on am'rous sportings bent, Like a sly archer take my stand; Wide through the world my shafts are sent, And every creature owns my hand.

First man, the lord of all below, A captive sinks beneath my dart; And lovely woman, made to glow, Yields the dominion of her heart.

Through sea, and earth, and boundles oky, The fond subjection all must prove, Whether they swim the stream or $\mathbf{f y}$, Mountain, or vale, or forest rove. 
Nor less the garden's sweet domain, The mossy heath or verdant mead, The tow'ring hill, the level plain, And fields with blooming life o'erspread. $-4$

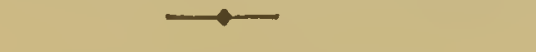

THE ALPINE VIOLET.

BY LORD BYRON.

T'He Spring is come, the violet's gone, The first-born child of the early sun; With us she is but a winter flower, The snow on the hills cannot blast her bower | And she lifts up her dewy eye of blue, To the youngest sky of the self-same hue.

But when the spring comes with her host Oi flowers, that flower, beloved the most, Shrinks from the crowd, that may confuse Her heavenly odours and virgin hues.

Pluck the others, but still remember Their herald, out of dire December; The morning star of all the flowers, The pledge of daylight's lengthen'd hours. And 'mid the roses, ne'er forget

The virgir, virgin viole . 


\section{TO A DAISY.}

B T WORDSWORTH.

Briant flower, whose home is every where.

A pilgrim bold in Nature's care, And oft, the long year through, the heir Of joy or sorrow ;

Methinks that there abides in thee

Some concord with humanity,

Given to no other flower I see

The forest through!

And wherefore? Man is soon deprest;

A thoughtless thing who, once unblest,

Does little on his memury rest,

Or on his reason:

But thou wouldst teach him how to find

A shelier under every wind;

A hope for times that are unkind,

And overy ceam. 


\section{THE IVY SONG.}

BY MRS. HEMANS.

Or . how could fancy crown with theo

In ancient days the god of wine,

And bid thee at the banquet be

Companion of the vine !

Ivy ! thy horne is where each sound

Of revelry hath long been o'er, Where song and beaker once went round

But now are known no more.

Where long-fallen gods recline,

There the place is thine.

The Roman on his battle plains,

Where kings before his eagles bent,

With thee, amidst exulting strains,

Shadow'd the victor's tent;

Though shining there in deathless green,

Triumphally thy boughs might wave

Better thou lovest the silent scene

Around the victor's grave.

Urn and sculpture half-divine

Yield their place to thine.

The cold halls of the regal dead,

Where lone the Italian sunbeams dwoll,

Where hollow sounds the lightest tread- 
Ivy ! t.rey know thee well!

And far above the festal vine,

Thou wavest where once proud banners hung,

Where mouldering turrets crest the Rhine,

-T'he Rhine, still fresh and young ! Tower and rampart o'er the Rhine, Ivy! ali are thine!

High from the fields of air look down

'i huse eyries of a vanish'd race, Where harp, and battle, and renown,

Have pass' $d$, and left no trace.

But thou art there ! serenely bright,

Meeting the mountain storms with bloom,

Thou that wilt climb the loftiest height,

Or crown the lowliest tomb!

Ivy, Ivy ! all are thine,

Palace, hearth, and shrine.

Tis still the same; our pilgrim tread

O'er classic plains, through deserts froe,

On the mute path of ages fled,

Still meets decay and thee.

And still let man his fabrics rear,

August in beauly, stern in power,

-Days pass-thou Ivy never sere!

And thou shalt have thy dower.

All are thine, or must be thine?

-Tem.lle, pillar, shrire! 


\section{DAFFODILS.}

B Y W R D W O TH.

I WANDER'D lonely as a cloud

That floats on high o'er vales and hil.t.

When all at once I saw a crowd,

A host of golden daffodils;

Beside the lake, beneath the trees,

Fluttering and dancing in the breeze.

Continuous as the stars that shine

And twinkle in the Milky-way,

They stretch'd in never-ending line

Along the margin of a bay:

Ten thousand saw I at a glance,

Tossing their heads in sprightly dance

The svaves beside them danced; but they

Outdid the sparkling waves in glee:

A poet could not but be gay,

In such a jocund company;

5 gazed-and gazed-but little thought

What wealth the show to me had brought 1

For oft when on my couch I lie,

In vacant or in pensive mood,

They flash upon that inward eye

Which is the bliss of solitude;

And then my heart with pleasure fille,

And dances with the daffodils. 


\section{A D ONIS' COUCH.}

\section{BY JOHN KEATS.}

ON a silken couch of rosy pride, In midst of all, there lay a sleeping youth Of fondest beauty ; fonder in fair sooth, Than sighs could fathom, or contentment reach And coverlids gold-tinted like the peach, Or ripe October's faded marigolds, Fell sleek about him in a thousand foldsNot hiding up an Apollonian curve Of neck and shoulder, nor the tending swerve Of knee from knee, nor ankles pointing light; But rather giving them to the fill'd sight, Officiously. Sideway his face reposed On one whıte arm, and tenderly unclosed, By tenderest pressure, a faint damask moutl, To slumbery pout; just as the morning south Disparts a dew-lipp'd rose. Above his head Four lily stalks did their wide honours wed To make a coronet; and round him grew All tendrils green, of every bloom and hue, Iogether intertwined and trammell'd fresh : The vine of glossy sprout; the ivy mesh, Shading its Ethiop bcrries; and woodbine, Of velvet leaves and bugle blooms divine; vonvolvulus in streaked vases flush ; The creeper, mellowing for an autumn blush; 
104 THE PC ITRY OP PLOW ESSE.

And virgin's-bower, trailing airily, With others of the sisterhood. Hard by, Stood serene Cupids watching silentiy. One, kneeling to a lyre, touched the stringe, Muffling to death the pathos with his wings; And, ever and anon, uprose to look At the youth's slumber; while another took A willow bough, distilling odorous dew, And shook it on his hair ; arother lew In through the woven roof, and fluttering wise, Rain'd violets upon his slopping eyes. 
TEI POETRY OF FLOWERS.

\section{E L OWER F'A TASIES.}

BY LOUISA ANN TWAMLEY.

$\mathrm{Oz}$ ! there is music to the spirit's ear

In every sigh

Heaved by the rose's bosom to the air

That winnows by ;

And there is poetry in every leaf,

Whose blusb speaks pleasure, or whose tears tell grief.

There is romance in every stem that bends

In motion soft

Beneath the wind that rustles in the tall

Tree-tops aloft,

And 'mid their branches whistlingly doth blow,

While it but fans the flowers that sleep below

We know they sleep; at eve the Daisy small

Foldeth all up

Her blush-tipp'd rays; and the wave's empress shuts

Her star-lit cup :

And each fair flower, though some with open eya cistens and yields to nature's lullaby.

- The Water Lily. 
The rodding Foxglove slumbers on he: stalk; And fan-like ferns

Seem poised still and slcepily, until

The morn returns

With singing-birds and beams of rosy ligh",

To bid them dance and frolic in delight.

The drowsy Poppy, who has all the day Proudly outspread

His scarlet mantle, folds it closely now Around his hcad;

And, lull'd by soothing balm that his own leaver distil,

Sleeps while the night-dews fall upon the moon. lit hill.

The fragrance is the spirit of the flower,

E'en as the soul

Is our ethereal portion. We can ne'er

Hold or control

One more than other. Passing sweet must bo

The visions, gentle things, that visit ye!

How happily ye live in the pure light

Of loveliness!

Do ye not feel how deeply-wondrously-

Ye cheer and bless.

Our chccker'd sojourn on this weary earth,

Whose wildest, dreariust spots to Flow ers have given birth? 
Do not ye joy to know the pure delight

With which we gaze

Upon your glorious forms?-Are ye not glad

E'en in the praise

Which our enraptured wonder ever tells While poring o'er the wealth that in ye dwells:

That wealth of thought, of beauty, and of love,

Which may be found

In each small common herb that springs from out

The teeming ground?

Do not ye feel that ye do deeply bless

Our harsher souls by your dear loveliness ?

Oh ! if 'tis given unto ye to know

The thrilling power

Of memories and thoughts that can be read

E'en in a flower,

How ye must all rejoice beneath each look

Which reads your beauty, like an open book!

We love its silent language: strong, though still,

Is that unheard

But all-pervading harmony:-it breathes

No utter'd word,

But floats around us, as, in happy dream,

We feel the soft sigh of a waveless stream.

So, love of nature's harmony can bless

And gladden ever 
The heart and fancy, as pellucid wave

Of fount or river

Flings back more bright what bright doth on it fall, And its own radialce lends where else were none at all.

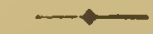

\section{SONNET.}

\section{B Y S P N S E R.}

SwEET is the Rose, but growes upon a brere; Sweet is the Juniper, but sharpe his bough; Sweet is the Eglantine, but pricketh nere; Sweet is the Firbloom, but his branches rough, Sweet is the Cypress, but his rind is tough, Sweet is the Nut, but bitter is his pill; Sweet is the Broome-flowcre, but yet sowre enough ;

And sweet is Moly, but his roote is ill. So every sweet with sowre is tempred stlll, That maketh it be coveted the more: For easie things that may be got at will, Most sorts of men loe set but little store. Why then should I account of little paine, That endless pleasure sha'.l unto me gaino 


\section{THE FLOWER-D I A L.}

BY MRS. HEMANS.

"I'was a lovely thought to mark the hours, As they floated in light away, By the opening and the folding flowers, That laugh to the summer's day.

Thus had each moment its own rich hue, And its graceful cup and bell, In whose colour'd vase might sleep the dew, Like a pearl in an ocean shcll.

'To such sweet signs might the time have flow' In a golden current on, Ere from the garden, man's first abode, The glorious guests were gone.

So might the days have been brightly toldThose days of song and dreams,When shepherds gather'd their flocks of cld. By the blue Arcadian streams.

So in those isles of delight, that rest

Far off in a breezeless main, Which many a bark, with a weary quest, Has sought, but still in vain. 
Yet is not life, in its real flignt,

Mark'd thus--even thus-on earth,

By the closing of one hope's delight,

And another's gentle birth?

Or ! let us live so that flower by flower,

Shutting in turn, may leave

A lingerer still for the sunset hour,

A charm for the shaded eve.

\section{SPRING FLOWERS.}

\section{BY SHAKSPEARE.}

\section{Daffodils}

That come before the swallow dares, and take

The wina's of March with beanty ; violets $\operatorname{dim}_{8}$

But sweeter than the lids of Juno's eyes, Or Cytherea's breath; pale primroses, That die unmarried, ere they can behold Bright Phœbus in his strength;

Bold oxlips, and

The crown imperial; lilies of all kinds,

The flower-do-luce being one. 


\section{THE POETEY OF RLOWER3. \\ BOWING ADORERS.}

\section{BY CLARE.}

Bowing adorers of the gale,

Ye Cowslips delicately pale,

Upraise your loaded stems;

Unfold your cups in splendour, speak !

Who deck'd you with that ruddy streak, And gilt your golden gems?

Violets, sweet tenants of the shade, In purple's richest pride array'd,

Your errand here fulfil;

Go bid the artist's simple strain

Your lustre imitate in vain,

And match your Maker's skill.

Daisies, ye flowers of lowly birth. Embroiderers of the carpet earth,

That stud the velvet sod;

Open to Spring's refreshing aur,

In sweetest smiling bloom declaro

$$
\text { Your Maker, and my God. }
$$




\section{F R A G M E N T.}

\section{BY COWPER.}

Somz clothe the soil that feeds them, far ditrused And lowly creeping, modest and yet fair, Like virtue, thriving most where little seen; Some more aspiring catch the neighbour shrub With clasping tendrils, and invest his branch, Else unadorn'd, with many a gay festoon, And fragrant chaplet, recompensing well The streng th they borrow with the grace they lend

\section{$\longrightarrow$ \\ TO A MOUNTAIN DAISY.}

ON TURNING ONE DOWN WITH THE PLOUAE

BY BURIS.

WEE, modest, crimson-tipped flower,

Thou'st met rne in an evil hour;

For I maun crush among the stour

Thy slender stem;

To spare thee now is past my power,

Thou bonnio gem. 


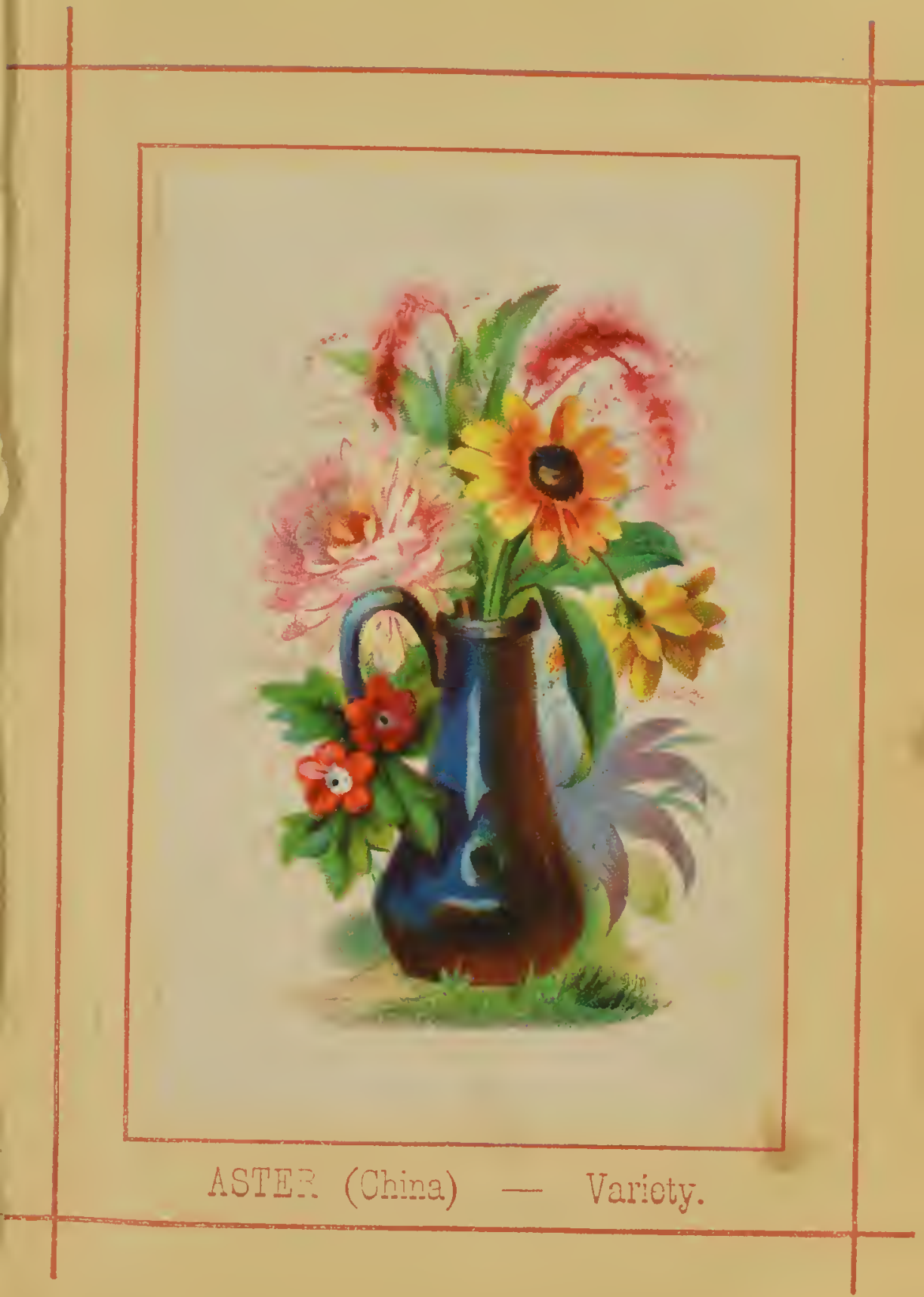



Alas! it's no thy neebour sweet, The bonnie lark, companion meet ! Bending thee 'mang the dewy weet?

$\mathrm{W} i$ ' speckled breast, When upward springing, tlithe, to greet The purplin' east.

Cauld blew the bitter biting north Upon thy early, humble birth:

Yet cheerfully thou glinted forth Aniid the storm, scarce rear'd above the parent earth, Thy tender form.

The flaunting flowers our gardens yield, High sheltering woods and wa's maun shield : But thou, beneath the random bield

$$
\text { O' clod or stane, }
$$

Adorns the histie stibble-field,

$$
\text { Unseen, alane. }
$$

There, in thy scanty mantle clad, Thy snowy bosom sunward spread, Thou lifts thy unassuming head In humble guise;

But now the share uptears thy bed, And low thou lies!

Such is the fate of artless maid, Sweet floweret of the rural shade ! 
By love's simplicity betray'd, And guilcless trust ;

Till she, like thee, all soil' $d$, is laid

Low i' the dust.

Such is the fate of simple bard, On life's rough ocean luckless starr'd ?

Unskilful he to note tlre card Of prudent lore,

Till billows rage, and gales blow hard, And whelm him o'er!

Such fate to suffering worth is given, Who long with wants and woes has striven By human pride or cunning driven To misery's brink, Till, wrench'd of every stay but heaven, He ruin'd sink !

E'en thou who mourn'st the Daisy's fate, That fate is thine-no distant date; Stern Ruin's ploughshare drivcs elatc, Full on thy bloom, Till cr'sh'd peneath the furrow's weight, Shall be thy doom 


\section{FHE POETRY OF FLOWERS. \\ THE BROKEN FLOWER.}

BY MRS. HEMANS.

On! wear it on thy heart, my love!

Stîl, still a little while!

Sweetnuss is lingering in its leaves,

Though faded be their smile.

Yet, for the salse of what hath been,

Oh! cast tt not away!

'Twas born to grace a summer scene,

A long, bright, golden day, My love,

A long, bright, golden day !

A little while around thee, love!

Its fragrance yet shall cling,

'Telling that on thy heart hath lain,

A fair, though faded thing.

But not even that warm heart hath power

To win it back from fate:-

Oh! I ain like thy broken flower,

Cherish'd too late, too late,

Cherish'd, alas! too 'nte

$$
\text { My love }
$$


116

\section{'TO 'THE SUNFLOWER.}

PRIDE of the garden, the beauteous, the regss,

The crown'd with a diadem burning in gold;

Sultan of flowers, as the strong-pinion'd eagle

And lord of the forest their wide empire hold.

Let the Rose boast her fragrance, the soft gales perfuming,

The 'Tulip unfold all her fair hues to me:

Yet though sweet be their perlume, therr ranbow dyes blooming,

I turn, noble Sunflower, with more love to theo.

There are some thiuk thy stateliness haughty, disdaining,-

Thy heaven-secking gaze lias no charm for their eyes;

'Tis because the pule spirit within thee that's reigning

Exalts thee above the vain pleasures they prize.

Emblem of constancy, whilst he is beaming, For whom is thy passion so steadfast, so true; May we, who of faith and of love are aye dreaming. Be taught to remember this lesson by you!

If on darth, like the Sunflower, our soul's beat devotion 
Shall turn to the source of 'Truth's far-beaning rays ;

O now blest, how triumplant, shall be our emotion,

When the bright ' Siun of Rigliteousness' bursts on our gaze.

\section{THE ROSE AND THE GAUNTLET.}

BY JOHN STERLING.

Low spake the Knight to the peasant girl, "I tell thee sooth-I am belted Earl; Fly with me from this garden small, And thou shall sit in my castle's ball.

"Thou shalt have pomp, and wealth, and pleasure,

Joys beyond thy fancy's measure;

Here with my sivord and horse I stand, To bear thee away to my distant land.

"Take, thou fairest! this full-blown rose,

A token of Love that as ripely blows." With his glove of steel he plucked the token, But it fell from his gauntlet crushed and broken. 
118

THE PCE'RY OF FLOWERS.

The maiden exclaimed-" Thou see's:, Sil Knight,

Thy fingers of iron can only smite;

And, like the rose thou hast torn and scatter'd, I in thy grasp should be wreck'd and shatter'd."

She trembled and blush'd, and her glances fell ; But she turn'd from the Kright, and said "Fare well ;"

"Not so," he cried, "will I lose my prize,

I heed not thy words, but I read thine eyes."

He lifted her up in his grasp of steel, And he mounted and spurr'd with furious heel ; But her cry drew forth her hoary sire, Who snatch'd his bow from above the fire.

Swift from the valley the warrior fled, Swifter the bolt of the cross-bow sped:

And the weight that pressed on the fleet-fort horse,

Was the living man, and the woman's corse.

That morning the rose was bright of hue :

That morning the maiden was fair to view :

But the evening sun its bcauty shed

On the withered leaves, and the maiden dead. 


\section{THE ROSE.}

\section{BY IVALLER.}

Go, lovely rose!

'oll her that wastes her time on ind,

'That now she knows, When I resemble her to thee, How sweet and fair she seems to be.

Tell her that's young And shuns to have her graces spied,

That hadst thou sprung In deserts where no men abide, Thou must have uncommended died

Small is the worth Of beauty from the light retired

Bid her come forth, Suffer herself to be desired. And not blush so to be admured.

Then die, that she The common fate of all things rare May read in thee; How small a part of time they share That are so wondrous swee: and fair. 
Yet, though thou fade,

From thy dead leaves let fragrance rine;

And teach the maid

That goodness time's rude hand defies;

That virtue lives when beauty dies

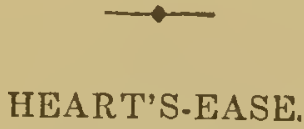

I OSED to love thee, simple flower, To love thee dearly when a boy;

For thou didst seem in childhood's hour

The smiling type of childhood's joy.

But now thou only work'st my grief, By waking thoughts of pleasures fled Give me-give me the wither'd leaf,

That falls on Autumn's bosom dead.

For that ne'er tells of what has been, But warns me what I soon shall be; It looks not back on pleasure's scene, But points unto futurity.

I love thee not, thou simple flower, For thou art gay, and I am lone; Thy beauty died with childhood's ho:arThe Heart's-ease from my a 
THE POFTRY OF TLOWERS.

\section{THE MOSS-ROSE.}

BY JOHN STERLING.

Mossy rose on mossy stone,

Flowering 'mid the ruins lone,

$I$ have learnt, beholding thee,

Youth and Age may well agree.

Baby germ of freshest hue, Out of ruin issuing new ;

Moss a long laborious growth, And one stalk supporting both:

Thus may still, while fades tho past

Life come forth again as fast;

Happy if the relics sere

Deck a cradle, not a bier.

Tear the garb, the spirit flies, And the hcart unshelter'd, dies;

Kill within the nursling flower, Scarce the grcin survives an hour.

Ever thus together live, And to man a lesson give,

Moss, the work of vanished yeare, Rose, that but to-day appears. 
Moss, that covers dateless tomt 3 ;

Bud with early sweet that blooms;

Childhood thus, in happy rest,

Lies on ancient Wisdom's breast.

Moss and Rose, and Age and Youth Flush and Verdıre, Hope and Truth, Yours be peace that kncws not strifo, One the root and one the life.

\section{THE HYACINTH.}

\section{BY CASIMIR.}

Carrd of the Spring, thou eharming flower,

No longer in confinement lie, Arise to light, thy form discover,

Rival the azure of the sky.

The rains are gone, the storms are o'er;

Winter retires to make thee way;

Come then, thou sweetly blooming flower,

Come, lovely stranger, come away.

The sun is dress'd in beaming smiles,

To give thy beauties to the day:

Young zephyrs wait with gentlest galea,

To fan thy bosom as they play. 


\title{
FLOUERS FOR THE.GRAVE.
}

\author{
BY N. P. WILLIS.
}

ג, ом, gentle flowers ' my child would pass to heaven!

Ye look'd not for her yet with your soft eyes, Oh watchful ushers at Death's narrow door! But lo! while you delay to let her forth, Angels, beyond, stay for her! One long liss From lips all pale with agony, and tears, Wrung after anguish had dried up with fire The eyes that wept them, were the cup of life Held as a welcome to her. Weep! oh mother ! But not that from this cup of bitterness A cherub of the sky has turn'd away! One look upon thy face ere thou depart! My daughter! It is soon to let thee go! My daughter ! With thy birth has gush'd a spring I knew not of-filling my heart with tears, And turning with strange tenderness to theeA love-oh God! it seems so-that must flow Far as thou fleest, and 'twixt heaven and me, Henceforward, be a bright and yearning chain Drawing me after thee! And so, farewell! 'Tis a harsh world, in which affection knows No place to treasure $\mathrm{tp}$ its loved and lost But the foul grave! 'Thou, who so late wat sleeping

Warrs ir. the close fold of a mother's heart 
Suaro 3 from her breast a single pulse receiving But it was sent thee with some tender thought, How ean I leave thee-here! Alas for man' The herb in its humility may fa!l And waste into the bright and genial air, While we-by hands that ministered in life Nothing but love to us-are thrust awayThe earth flung in upon our just eold bosoms, And the warm sunshine trodden out for ever'

$Y$ et have 1 chosen for thy grave, my child, A bank where I have lain in summer hours, And thought how little it would seem like death To sleep amid sueh loveliness. The brook, Tripping with laughter down the rocky steps 'That lead up to thy bed, would still trip on, Breaking the dread hush of the mourners gone; The birds are never silent that build here, Trying to sing down the more vocal waters; The slope is beautiful with moss and flowers, And far below, seen under arehing leaves, Glitters the warm sun on the village spire, Puinting the living after thee. And this Soems like a comfort; and, replacing now The flowers that have made room for thee, I go To whisper the same peace to her who liesRobb'd of her ehild and lonely. 'Tis the work Of many a dark hour, and of many a prayer, To bring the heart back from an infant gone. Hope nust give o'er, and busy fancy blo The images from all the silent rooms, 
And every sight and sound familiar to her Undo its sweetesi link-and so at last The fountain-that, once struck, must flow for ever-

Will hide and waste in silence. When the smile

Steals to her pallid lip again, and spring Wakens the buds above thee, we will come, And, standing by thy music-haunted grave, Look on each other cheerfully, and say:A child that we have loved is gone to heaven, And by this gate of flowers she pass'd away!

\section{THE QUEEN OF THE GARDEN}

\section{BY MOORE.}

If Jove would give the leafy bowers A queen for all their world of flowers, The Rose would be the choice of Jove And reign the queen of every grove. Sweetest child of weeping morning, Gem, the vest of earth adorning, Lye of flowerets, glow of lawns, Bud of beauty, nursed by dawns; Soft the soul of love it breathes; Cypria's brow with magie wreathes; And to the zephyr's warm caresses Difiuses all its verdant tresses, Till, glowing with the wanton's play, It Jlushes a diviner ray! 


\section{THE COWSLIP.}

U.NFoLDing to the breeze of May, 'The Cowslip greets the vernal ray; The topaz and the ruby gem, Her hlossom's simple diadem; And, as the dew-drops gently fall, They tip with pearls her coronal.

In princely halls and courts of king* Its lustrious ray the diamond flings; Yet few of those who see its beam, A mid the torch-light's dazzling gleam, As bright as though a meteor shone, Can call the costly prize their own. But gems of every form and hue Are gl tlering here in morning dew; Jewels that all alike may share As freely as the common air ; No niggard hand, or jealous eye, Protects them from the passer by. Man to his brother shuts his heart, And Science acts a miser's part ; But Nature, with a liberal hand, Flings wide her stores o'er sea and land If gold she gives, not single grains Are scatter'd far across the plains; But lo, the desert streams are roll'd O'er precious beds of virgin gold. If flowers she offers, wreaths are given, As countless as the stars of heaven: 
Or music- 'tis no feeble note

She bids along the valleys float;

Ten thousand nameless melodies

In one full chorus swell the breeze.

$\mathrm{Oh}$, art is but a scanty rill

That genial seasons scarcely fill.

But nature needs no tide's return

To fill afresh leer flowing urn :

She gathers all her rich supplies

Where never-failing waters rise."

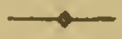

\section{TO THE ROUND-LEAFED SUNDEW.}

By the lone fountain's secret bed, Where human footsteps rarely tread, 'Mid the wild moor of silent glen, The Sundew blooms unseen by men; Spreads there her leaf of rosy hue, A chalice for the morning dew, And, ere the summer's sun can rise, Drinks the pure waters of the skies.

Wouldst thou that thy lot were given. Thus to rcceive the dews of heaven, With heart prepared, like this meek flowa ? Come, then, and hail the dawning hour; So shall a blessing from on high, Pure as the rain of summer's sky, 
Unsullied as the morning dew,

Descend, and all thy soul imbue.

Yes! like the blossoms of the waste

Would we the sky-born waters taste,

To the High Fountain's sacred spring

The chalice let us humbly bring :

So shall we find the streams of heaven

To him who seeks art freely given;

The morning and the evening dew

Shall still our failing strength renew.

\section{A CYPRESS LEAF,}

FOR THE GRAVE OF A DEAR ONE.

Tre feelings I have felt have died away,

The love that was my lamp death's dews have quench'd ;

The faith which, through life's ills, ne'er knew decay,

Hath in the chill showers of the grave been drench'd ;

The hopes that buoyed my spirit 'mid the spray Of life's wild ocean, one by one are wrench'd-. Cruelly wrench'd away,- -and I am now A solitary leaf on a rent bough!

The link that knit me to mankind is snapp'dBriefly it bound me to a callous world; 
T'he fortress of my comfort hath been sapp'd--

Where are Joy's banners, lightsomely unfurl'd, That graced the battlements? In vapor wrapp'd In the dense smoke of stifled breath upcurl'd, They drop in tatters-forming now a pall For the sad mummy-heart that drips with gall.

I have not now of broken troth to wail, I have not now to speak of friendship broken; Of Death and Death's wild triumphs is my taleOf friendship faithful, and of love's last token, A ring ! - whose holy motto ne'e1 shall fail To rouse such sorrow as may ne er be spoken That pictured Dove and Branch-those words 'La Paix!'

O direful mockcry!) wear my heart away!*

'Peace ?'-Peace! alas, there is no peace for me. It rests with thee, beloved one! in the grave! Yet, when I search the cells of Memory,

Where silently the subterranean wave Of buried hope glides oll, a thought of theeLike sunshine on the hermit's darkened caveSteals gently o'er my spirit, whispering siveet Of realms beyond the tomb, where we shall meet!

* A melancholy anecdote is at tached to these lines: the motto ' LA PAIX' was engraven on the bequeathed gift of a beloved friend, who, in the bloom of youth fell a victim to sudden and violers death in India. 
Our love-how did it spring? In sooth it grew Even as some rare exotic in a clime Unfriendly to its growth : yet rich in hue. Voluptuous in fragrance, as if Time Had oeen to it all sunlight and soft dew,$\Lambda \mathrm{s}$ if upon its freshness the cold rime of death should nrver fall! How came it then ? Even as the manna fell 'midst famish'd men.

To be snatch'd up in transport! And we fed Upon affection's banquet, that ne'er pall'd Upon the spirit's palate! Friendslip shed

A light around our bosoms which recall'd 'The memory of that bard, whose soul was wedWith love surpassing woman's love, ungall'd By selfish doubts- to him, the monarch's son, Brave Jonathan! Like their's, our souls were on $\bullet$

Oh : long we loved in slence! Neither spake of that which work'd the thoughtful mino within;-

Thou didst not guess that, sleeping or awake,

My thoughts were full of thee till thought grow sin:

For it is sin of earthly things to make Our idols! and I never hoped to win Thy coveted affection; but for me, Thy heart was als. yearring eilently : 
I was the thrst to speak--and words there were, Wild words, that painted fond affection's course ;-

0 ! what indeed will erring tongues not dare, When conquering Feeling prompts! Liko winds that force

From wind-harps mystic sounds, the lips declare, Thoughts that are often follow'd by remorse; For passion hath a potency that breaks Each puny bulwark callous Reason makes!

But our's was Friendship's purest worship--pure, Altho' that worship bowed at earthly shrines, Alas! that hearts on altars insecure

Should sacrifice their all of bliss! Thero twines

O'er mankind's sweetest hopes corruption sure, 'To blast their beauty e'en whilst most it shines!-

'Tis bu! to teach us there are worlds above, Where Hope fruition fnds in endless I_ove! 


\section{WILD FLOWERS.}

BY JOHN KEATS.

I stion tiptoe upon a little hill;

The air was cooling, and so very still, That the sweet buds which with a moaest prido Fell droopingly in slanting curve aside,

Their scanty-leaved and finely tapering stems Had not yet lost their starry diadems,

Caught from the early sobbings of the morn.

The clouds were pure and white as flocks new shorn,

And fresh from the clear brook; sweetly they slept

On the blue fields of heaven, and then there crept

A little noiseless noise among the leaves,

Born of the very sigh that silence heaves;

For not the faintest motion could br seen

Of all the shades shat slanted o'er ar green.

There was wide wandering for the greediest eye,

To peer about upon variety;

Far round the horizon's crystal air to skim,

And trace the dwindled edgings of its brim;

To picture out the quaint and curious bending

Uf a fresh woodland alley never-ending:

Or by the bowery cleíts and leafy shelves,

Guess where the janty streams refresh thora. selves. 
1 gazed awhile, and felt as light and free As though the fanning wings of Mercury Had play'd upon my hcels: I was light-hearted, And many pleasures to my vision started; So I straightway began to pluck a posy Of luxuries bright, milky, soft and rosy. A bush of May-flowers with the bees about them; Ah, sure no tasteful nook could be without them; And let a lush laburnum oversweep them, And let long grass grow round the roots, to keep them

Moist, cool and green; and shade the violets, That they may bind the moss in leafy nets. A filbert edge with wild-brier overtwined, And clumps of woodbine taking the soft wind Upon their summer thrones; there too should bo The frequent chequer of a youngling tree, That with a score of bright-green brethren shoots From the quaint mossiness of aged roots : Round which is heard a spring head of clear waters,

Prattling so wildly of its lovely daughters, The spreading blue-bells : it may haply mourn That such fair clusters should be rudely torn From their frcsh beds, and scatter'd thoughtlessis By infant hands left on the path to die. Open afresh your round of starry folds, Ye ardent marigolds!

Dry up the moisture from your golden lids. For great A pollo bids 
That in thesc days your praises should be sung On many harps, which he has lately struirg; And when again your dowiness he kisses, Tell him, I have you in my world of blisses: So haply wren I rove in some far vale, His mighty voice may come upen the gale.

Here are sweet-peas, on tiptoe for a flight : With wings of gentle flush o'cr delicate white, And taper fingers catching at all things, To bind them all about with tiny rings. What next? a turf of evening primroses, O'er which the mind may hover till it dozes; O'er which it well might take a pleasant sleed, But that 'tis ever startled by the leap Of buds into ripe flowers.

\section{THE JASMINE.}

\section{BY MOORE.}

'Twas midnight-through the lattice wreath'd

With woodbine, many a perfume breathed

From plants that wake when others sleep;

From timid jasmine buds that keep

'T'heir odour to themselves all day;

But when the sunlight dies away,

Let the delicious secret out

To every breeze that roams about. 
THE POETRY OF FIC WERS.

\section{TO PRIMROSES}

\section{FILLED WITH MORNING DEW. \\ BY HERRICR.}

W $\mathbf{\text { y }}$ dc ye weep, sweet babes? Can team

Speak grief in you,

Who were but born

Just as the modest morn

Teem'd her refreshing dew !

Alas! ye have not known that shower

That mars a flower ;

Nor felt the unkind

Breath of a blasting wind;

Nor are ye worn with years;

Or warp'd as we,

Who think it strange to see

Such pretty flowers, like to orphans young, Bpeaking by tears before ye have a tongue.

Bpeak, whimpering younglings, and make know a

The reason why

Ye droop and weep.

Is it for want of sleep,

Or childish Iullaby?

Or that ye have not seen as yet

The violet?

Or brought a kiss

From shat sweetheart to this t 
136 THE PCETKY OF FI,OWERS.

No, no; this sorrow shown

By your tears shed,

Would havo this leeture read:

That things of greatest, so of meanest w rth, Conceived with grief are, and with tears brough forth.

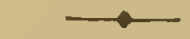

\section{THE DAISY.}

BY JOHN MASON GOOD.

Not worlds on worlds, in phalanx deep,

Need we to prove that God is here;

The daisy, fresh from winter's sleep,

Tells of His hand in lines as clear.

For who but he who arch'd the skies,

And pour'd the day-spring's living floo

Wondrous alike in all He tries,

Could rear the daisy's purple bud;

Mould its green cup, its wiry stem,

Its fringed border nicely spir,

And cut the gold-embossed gem

That, set in silver, gleams within; 
And fling it unrestrain' $d$ and free,

O'er hill and dale, and desert sod,

That man, where'er he wallss, may ses,

At every step, the stamp of God?

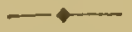

\section{FROM METASTASIO.}

The married are compared by the poet to the young Rose, which the lover places in the bosorn of his mistress, first stripped of thorns.

Thо virgin Rose! whose opening leaves so fair, The dawn has nourish'd with lier balmy dews While softest whispers of the morning air

Call'd forth the blushes of thy vermeil hues;

That cautious hand, which cropt thy youthful pride, Transplants thy honours, where from hurt secure,

Stript of each thorn offensive to thy side,

Thy nobler part alone shall bloom mature.

Thus thou, a flower, exempt from change of skies, By storms and torrents unassail'd shall rise, And scorn the winter colds, and summer heats; A guard more faithful then thy growth shall tend. By whom thou mayst in tranquil union blend Eterna' beauties with etert al sweets. 


\section{'THE LILY. \\ J . H . W I F F E N .}

Look on that flower-the daughter of the valo The Medicean statue of the shade!

Her limbs of modest beauty, aspect fale, Are but by her ambrosial breath betray'd.

'There, half in elegant relief display'd,

She standeth to our gaze, half-shrinking shuns;

Folding her green scarf like a bashful maid

Around, to screcn her from her suitor suns,

Not all her many sweets she lavisheth at once.

Lock'd in the twilight of depending boughs,

Where night and day commingle, she doth shoot,

Where nightingales repeat their marriage vows;

First by rctiring, wins our curious foot,

Then charms us by her loveliness to suit

Our contemplation to her lovely lot;

Her gloom, leaf, blossom, fragrance form dispute

Which shall attract most belgards to the spot, And loveliest her array who fain would rest un sought.

Her gloom, the aisle of heavenly solitude;

Her flower, the vestal nun who there abideth;

Her breath, that of celestials meekly woo'd

From heaven; her leaf, the holy veil which hideth ;

Her form, the shrine where purity reaideth 
Spring's darling, nature's pride, the sylvan's queen-

To her at eve enanour'd Zephyr glideth, Trembling, she bids him waft aside her screen, And to his kisses wakes-the Flora of the scene

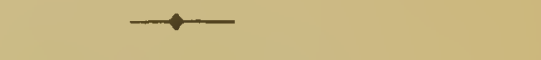

\section{THE NARCISSUS.}

\section{BY GAY.}

Here young Narcissus o'er the fountain stood, And view'd his image in the crystal flood; The crystal flood reflects his lovely charms, And the pleased image strives to meet his arms. No nymph his inexperienced breast subdued, Echo in vain the flying boy pursued. Himself alone, the foolish youth admires, And with fond look the smiling shade desires; O'er the smooth lake with fruitless tears he grieves ;

His spreading fingers shoot in veräant leaves : Through his pale veins green sap now gently flowa, And in a short-lived flower his beauty blows. Let vain Narcissus warn each female breast, That beauty's but a transient good at best; Like flowers it withers with th' advancing year, And age like winter robs the blooming fair. 


\section{A SONG OF THE RGSE.}

BY MRS. HEMANS.

Rose! what dost thou here?

Bridal, royal rose?

How, 'midst grief and fear,

Canst thou thus disclose

That fervid hue of love which to thy heart.led glows?

Rose ! too much array'd

For triumphal hours,

Look'st thou through the shade

Of these mortal bowers,

LNot to disturb my soul, thou crown'd one of all flowers!

As an eagle soaring

Through a sunuy sky,

As a clarion poliring

Notes of victory,

So dost thou kindle thoughts, for earthly life too high -

Thoughts of rapture, flushing

Youthful poet's cheek,

Thoughts of glory rushing

Forth in song to break,

But finding the spring-tide of rapid song too weak 
THE POETRY OF LOWHRB.

141

Yet, oh! festal rose,

I have seen thee lying

In thy bright repose

Pillow'd with the dying,

Thy arimson by the life's quick bloor was figing

Summer, hope, and love

O'er that bed of pain,

Meet in thee, yet wove

Too, too frail a claim

In its embracing links the lovely to detain.

Smilest thou, gorgeous flower ?-

0 ! within the spells

Of thy beauty's power

Something dimly dwells,

At variance with a world of sorrows and farewells.

All the soul forth flowing

In that rich perfurre,

All the proud life glowing

In that radiant bloom,

Have they no place but here, beneath th' o'ershadowing tomb?

Crown'st thou but the daughters

Of our tearful race?-

Heaven's own purest waters

Well might bear the trace

Of thy consummate form, melting to softer grace. 
- Will that clime enfold thee

With immortal air?

Shall we not behold thee

Bright and deathless there?

In spirit-lustre clothed, transcendenty more fair 1

Yes! my fancy sees thee

In that light disclose,

And its ofream thus frees thee

From the mist of woes,

Darkening thine earthly bowers, O bridal, royal rose.

\section{$\longrightarrow$ \\ THE ROSE.}

FROM BEAUMONT AND FLETCHER.

OF all flowers.

Methinks a rosc is best ......

It is the very emblem of a maid;

For when the west wind courts her gently, How modestly she blows, and paints the sun

With her chaste blushes! When the north comes near her,

Rude and impatient, then, like chastity, She locks her beauties in her bud again, And lnaves hiru to base briers. 


\section{THE CAPTIVE AND THE FLOWERS.}

FROM THE GERMAN OF GOETHE.

CAPTIVE.

A FLower that's wondrous fair, I know,

My bosom holds it dear ;

To seek that flower I long to go,

But am imprison'd here.

'Tis no light grief oppresse: me;

For in the days my steps wcre free,

I had it alwavs near.

Far round the tower I send mine eye

The tower so steep and tall;

But nowhere can the flower descry

From this ligh castle wall ;

And him who'll bring me my desire,

Or be he knight, or be he squire,

My dearest friend I'll call.

\section{ROSE.}

My blossoms near thee I disclose, And hcar thy wrctched plight ;

Thou meanest me, no doubt, the roes Thou noble, hapless knight.

A lofty mind in thce is seen, And in thy bosom reigns the queen

of flowers as is her right. 
CAPTIVE.

Thy crimson bud I duly prize

In outer robe of green ;

For this thou'rt dear in maiden's eyou.

As gold and jewels sheen.

Thy wreath adorns the fairest brow, And yet the flower-it is not thou,

Whom my still wishes mean.

LILY.

The little rose has cause for pride, And upwards aye will soar;

Yet am I held by many a bride

The rose's wreath before.

And beats thy bosom faithfully, And art thou true, and pure as I,

Thou'lt prize the lily more.

CAPTIVE.

I call myself both chaste and pure, And pure from passions low ;

And yet these walls my limbs immuro In loneliness and woe.

Though thou dost seem, in white array 4

Like many a pure and beauteous maid, One dearer thing I know.

PINK.

And dearer I, the pink, must pe, And me thou sure dost choose, Or else the gard'ner ne'er for mo Such watchful care would use; 
A crowd of leaves enriching bloom ! And mine through life the sweet perfume, And all the thousand hues.

CAPTIVE.

The pink can no one justly slight, The gard'ner's favourite flower; He sets it now beneath the light. Now shields it from its power. Yet 'tis not pomp, who o'er the rest In splendour shines, can make me blest It is a still, small flower.

VIOLET.

I stand conceal'd, and bending low, And do not love to speak ; Yet will I, as 'tis fitting now, My wonted silence break. For if 'tis I, thou gallant man, Thy heart desires, thine, if I can, My perfumes all I'll make.

\section{CAPTIVE.}

The violet I esteem indeed, So modest and so kind; Its fragrance sweet yet nore I need, To soothe mine anguish'd mind. To you the truth will I confess; Here, 'mid this rocky dreariness, My lova ' ne'er shall find. 
The truest wife by yonder brook

Will roam the mournful day, And lither cast the anxious look,

Lnng as immured I stay.

Whene'er she breaks a snall blue flower, And says, "Forget me not!" the power

I feel, though far away.

Yes, e'en though far, I feel its might.

For true love joins us twain,

And therefore 'mid the dungeon's night

I still in life remain.

And sinks my heart at my hard lot, I but exclain, "Forget me not!"

And straight new life regain.

\section{FRAGMENT.}

\section{BY SIR WALTER SCOTT.}

AND well the lonely infant knew Recesscs where the wall-flower grew And honeysuckle loved to crawl Up the low crag and ruin'd wall. I deem'd such nooks the sweetest shade The sun in all his round survey'd, And still I thought that shattcr'd tower: The mightiest work of human power. 
THE POETRY OF FLOWERS.

\section{THE VIOLET:*}

$\%$

3 G. J. C L A R K E.

Wrer April's warmth unlocks the clod,

Softon'd by gentle showers,

The violet pierces through the sod,

And blossoms, first of flowers;

So may I give my heart to GoD

In childhood's early hours.

Some plants, in gardens only found,

Are raised with pains and care :

Gop scatters violets all around,

They blossom every where;

Thus may my love to all abound,

And all my fragrance share.

Some scentless flowers stand straight and high

With pride and haughtiness :

But violets perfume land and sky,

Although they promise less.

Let me, with all humility,

Do more than I profess.

- Written for a little girl to speak on May-day, in we sharacter of the Violet. 
Sireet flower, be thou a type to mo Of blameless joy and mirth, Of widely-scatter'd sympathy,

Embracing all GoD's earthOf early-blooming piety,

And unjretending worth.

\section{SEND THE LILIES GIVEN T M}

\section{BY BYRON.}

I sEND the lilies given to me,

Though, long before thy hand they touch,

I know that they must wither' $\mathrm{l}$ be ;

But yet reject them not as such :

For I have cherish'd them as dear,

Because they yet may meet thine eye, And guide thy soui to mine even here,

When thou behold'st them drooping nig And know'st them gather'd by the Rhiune And offer'd from my heart to thine!

The river nobly foams and flows,

The charm of this enchanted ground.

And all its thousand turns disclose

Some fresher beauty varying round; 
The haughtiest breast its wish might bound, 'Tlirough life to dwcll delighted here; Nor could on eartin a spot be found T'o nature and to me so dear. Could thy dear eyes, in following mine, Still sweeten more these banks of Rhine!

FADED FLOWERS.

BY MRS. SARAH HELEN WHITMAN.

Remembrancers of happiness ! to me

Ye bring sweet thoughts of the year's purplo prime,

Wild, mingling melodies of bird and bee

That pour on summer winds their silvery chime;

And of rich incense, burdening all the air,

From flowers that by the sunny garden wall

Ploom'd at your side,-nursed into beauty there

By dews and silent showers; but these to all

Ye bring. Oh! sweeter far than these the spell

Shrined in those fairy urns for me alone,

For me a charm sleeps in each honey'd cell

Whose power can call back hours of rapture flown,

To the sad heart sweet memories restore,

Tones, looks, and words of love that may re turn no more. 
TO DAFFODILS.

B GEORGE HER RIC

Fair daffodils, we weep to see

You haste away so soon;

As yet, the early-rising sun

Has not attain'd its noon.

Stay, stay,

Until the hastening day

Has run

But to the even song;

And having pray'd together, we

Will go with you along.

We have short time to stay as you.

We have as short a spring;

As quick a growth to meet decay,

As you or any thing.

We die,

As your hours do, and dry

Away,

Like to the summer's rain.

Or as the pearls of morning's dow

Ne'er to be fourd again. 
THE POETRY C F IOWERS.

\section{WHITE ROSES.}

\section{BY SARAH LOUISA P. SMITH.}

'неу were gather'd for a bridal!

I knew it by their hue :

Fair as the summer moonlight

Upon the sleeping dew.

From their fair and fairy sisters

They were borne, without a sigh,

For one remember'd evening

To blossom and to die.

They were gather' $d$ for a bridal !

And fasten'd in a wreath ;

But purer were the roses

Than the heart that lay beneath;

Yet the beaming eye was lovely,

And the coral lip was fair,

And the gazer look'd and ask'd not

For the secret hidden there.

They were gather'd for a bridal'

Where a thousand torches glisten ${ }^{\prime} d_{\text {, }}$

When the holy words were spoken,

And the falsc and faithless lisien'd

And answered to the vow

Which another heart had taken,

$Y$ et he was present then-

The once loved, the forsaken. 
They were gather'd for a bridal !

And now, now they are dying,

And young Jove at the altar

Of broken faith is sighing.

Their summer life was stainless,

And not like her's who wore them

They are faded, and the farewell

Of beauty lingers o'er them !

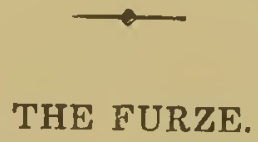

'Mrn scatter'd foliage, pale and sere,

Thy kind floweret cheers the gloom;

And offers to the waning year

The tribute of its golden bloom.

Beneath November's clouded sky,

In chill December's stormy hours, 'Thy blossom meets the travel'er's eye,

Gay as the buds of summel bowers.

Flower of the dark and wintry day!

Emblem of friendship! thee I hail!

Blooming when others fade away,

And brightest when their hues grow pale 


\title{
NIGHT-BLOOMING FLOWERS.
}

\author{
BY JULIET H. LEWIS.
}

F LIR buds! I've wander'd day by day

To this sequester' $d$ spot,

That I might catch your earliest smiles,

And yet, you open not.

The morning mists are scattered now,

No cloud is in the sky,

The sun, like a benignant king,

Smiles from his throne on high;

While birds, in gushing melody,

Are offering homage up ;

And sister flowers, beneath his gaze,

Ope wide each fragile cup.

Why shut you then your incense in,

And hide your loveliness,

As though no one might share your joy

Beneath the sun's caress?

Now wake you, 'tis the sunset hour,

The day-lking has gone down;

Yet still, above the mountain's top,

Is seen his brilliant crown;

Awake you! if his gleaming gems,

His bands of glittering gold,

His glorious, life-like radiance

Departing, you'd tehold. 
The river's touch'd with glowing light, And rolls, a crimson flood;

While heaven's blush has lent its liues Unto the leafy wood.

Still, are you folded to your dreams?

Bright must those visions be,

If they surpass the gorgeousness Of evening's pageantry!

Good niglit! the stars are gemming heaver, And seem like angel's eyes, Resuming now their silent watch Within the far-off skies;

They nightly on their burning thrones

Like guardian spirits, keep

Familiar vigil o'er the world, Wrapt in its solemn sleep; And tenderly they gaze on us, Those children of the air, While every ray they send to us, Some message seems to bear, That stirs us to the inmost core; And we do thrill beneath their beams, And start, and tremble, wildly, like Ambition in his dreams.

Now, lo! you burst your emerald bonds, And ope your languid eyes, And spread your loveliness before Those dwellers of the skies: 
Wrile incense, from your grateful hearts, Like prayer ascends to heaven; And kindly dew, and starry light, Are answering blessings given.

"Ask and ye shall receive," you seem To whisper to my heart, And move me in your worshipping

To take an active part.

Sweet teachers! 'tis an hour for prayer,

When hush'd are sounds of mirth, And slumber rests his balmy wing Upon the weary earth:

When all the ties that bind the soul To worldliness, are riven-

Then heart-felt prayers, like looson ${ }^{\circ}$ burd Will wing their way to heaven. 


\title{
THE FLOWER-GARDEN.
}

\author{
BY R. M. MILNES.
}

O fENsIVE Sister ! thy tear-darken'd gaze

I understand, whene'er thou look'st upon

The Garden's gilded green and colour'd blaze,

The gay society of flowers and sun.

Thou thinkest of the withering that must come,

'The quenching of this radiance all around, The hastening change in Nature's merriest home, The future blackness of the orphan'd ground.

Thon thinkest too of those more precious blooms The firstling honours of thy Life's fresh field, The childly feelings that have all their tombs, The hopes of youth that now no odours yield:

Sttill many a blessed sense, in living glee, Waves its bright form to glorify thy breast, But this fair scene's perverse morality

Tells thee, they all will perish like the rest:

Yet pluck them, hurt them not; whate'er betid $\mathbf{s}$, Tousch not with wilful force those flowers $0^{*}$ thine,-

Let death receive them, his inviolate brides, They are the destined vestals of bis shrine. 
And it tnose children of the insensate earth Go down in peace to a prolific grave,If $\mathrm{N}_{\text {ature ralses }}$ in continuous birth The plant whose present grace slie will ros save,-

So some deep-grounded root or visible seed,

When these heart-blossoms fade, may still remain,

In a new season of thy being, decreed

To rise to light and loveliness again.

\title{
THE FRAGRANT AIR-FLOWER.
}

\author{
BY T. R. HERVEY.
}

MEN say there is a gentle flower, That, born beneath an eastern sky, Without the gift of sun or shower,

Gives ont its precious sigh .

That-with affection-sweetly dwells

Beneath the Indian's stately doom.

Or freely throws its fragraint spells

Around his lowly home,-

Fed only by that sacred air

That, as a spirit, hovers there? 
And thou art like that fairy thing, Though gifted with a colder sky, With scent and bloom, too pure to fling

Before the passer by ;

Who, with the star-flowers of thine eyes, Couldst brighten still the brightest lot, Or, with thy fond and fragrant sighs, Make rich the poor man's cot! An English Ruth,-in good or ill, 'To follow wheresoe'er we roam, And hang thy precious garlands, still, Amid the breath of home!

-My weary heart! my wear heart ' It is a pleasant thing To wander from the crowd apart, When faint, and chill'd, and cold thou And fold thy restless wing,

Beside the sweet and quiet streams Where grow life's lily.bells, And peace-that feeds on happy dreans And utters music, -dwellsAnd love, beside the gushing springs, Like some young Naiad, sits and sinpo'

To leave awhile the barren height, Where thou, too long, hast striven As if the spirit's upward flight Had been the nath to heaven. 
THE POETRY OF FLOWUES.

159

A rid musing by love's haunted rill,

Earth's "river of the blest,"

To see how sweetly heaven still,

Is mirror'd on its breast,

And feel thou, there, art nearer far

To that bright land of sun and star!

\section{THE ALPINE FLOWERS.}

\section{BY MRS. SIGOURNEY.}

Mzer dwellers 'mid yon terror-stricken cliffs ! With brows so pure, and incense-breathing lips, Whence are ye?-Did some white-wing'd mo senger

On Mercy's missions trust your timid germ

To the cold cradle of eternal snows ?

Or, bresthing on the callous icicles,

Bid shem with tear-drops nurse ye?-

- Tree nor shrub

Dare that drear atmosphere: no polar pine Uprears a veteran front; yet there ye stand, Leanıng your cheeks agrainst the thick-ribb'd ico And looking up with brilliant eyes to Him Who bids you bloom unblanch'd amid the wasto Of desolation. Man, who, panting, toils $D$ er slippery steeps. or, trembling treads the vergo 
Of yawning gulfs, o'er which the headlong plunge Is to etcrnity, looks shuddering up, And marks ye in your placid lovelinessFearless, yet frail--and, clasping his chill hands, Biesses your pencill'd beauty. 'Mid the pomp Of mountain summits rushing on the sky, And chaining the rapt soul in breathless awe, He bows to bind you drooping to his breast, Inhales your spirit from the frost-wing'd gale, And freer dreams of heaven.

\section{THE MISTLETOE.}

\section{BY BARRY CORNWALL}

WHEN winter nights grow long,

And winds without blow cold,

We sit in a ring round the warm wood-ture,

And listen to stories old!

And we try to look grave (ay maids should be, )

When the men bring in boughs of the laurel-tree

$O$, the Laurel, the evergreen tree!

The Poets have laurels-and why not we?

How pleasant, when night falls down,

And hides the wintry sun,

To see them come in to the blazing fir $\theta_{y}$

And know that their work is done; 
While many bring in, with a laugh or rhyme, Green branclies of holly for Christmas time!

0 the Holly, the bright green Holly, It tells (like a tongue) that the times are jolly.

Sometimes-in our grave-house,

Observe, this happeneth not; But, at times, the evergreen laurel boughs And the holly are all forgot!

And then! what then? why, the men laugh low, And hang up a branch of-the Mistletoe!

Oh. brave is the Laurel! and brave is the Holly! But the Mistletoe banisheth melancholy! Ah, nobody knows, nor ever shall know What is done-under the Mistletas? 


\section{TO THE PRIMROSE.}

\section{BY BIDLAKE,}

Pare visitant of balmy spring, Joy of the new-born year, That bidd'st young hope new-plume his wing,

Soon as thy buds appear:

While o'er the incense-breathing sky

The tepid hours first dare to fly, And vainly woo the chilling breeze That, bred in winter's frozen lan. Still struggung chains the lingerıng sap Within the widow'd trees.

Remote from towns, thy transient life Is spent in skies more pure;

The suburb smoke the seat of strife, Thou canst but ill endure.

Coy rustic! thou art blooming found Where artless nature's charms abound,

Sweet neighbour of the chanter rill; Well pleased to sip the silvery tide, Or nodding o'er the fountain's side, Self-gazing, look thy fill; 
THE POETRY OF FIOWERS,

Ur, on the dingle's shadowy steep, The gaudy furze beneath,

Thy modest beauties sweetly peep,

Thy chaster odours breathe.

From luxury we turn aside, From wealth and ostentatious pride,

With many an emblematic thorn, Thy humbler mien well pleased to meet;

Like competence in blest retreat, Thy smiles the spring adorn:

What though thou boast no splendid huo Of Flora's prouder race?

To me more fair art thou to view,

In all thy simple grace :

Thine innocence and beauty meek, More like my Celestina's cheek,

Where all the modest virtues play;

Expression beaming from her eye,

In cherub smiles of chastity,

With mild and temper'd ray.

Yet treasures lurk within thy lips

To glad the spoiler bee,

Who not with idle errand sips,

Or wanton vagrancy.

Ah ! blest is he who temperance tries,

Simplicity above disguise, 
And shums the falser gloss of art;

'Tis he extracts a bliss refined,

Congenial to the virtuous mind,

The tender feeling heart.

Thy smiles young innocence invite,

What tine thy lids awake,

In shadowy lane to taste delight,

Or mazy tangled brake.

The infant troop of rosy hue,

And gay with health I seem to view,

While pleasure lights their laughing eyea

With little hands a wreath combine,

Their fugitive delights entwine,

And boast their fragrant prize.

Ah ! happy breasts ! unknown ro pain

I would not spoil your joys;

Nor vainly teach you to complain

Of life's delusive toys.

Be jocund still, stil! sport and smile,

Nor dream of woe or future guile ;

For soon shall ye awaken'd find

The joye of life's sad thorny way,

But fading flowerets of a day

Cut down by every wind. 


\section{THE VIOLET.}

\section{BY BARRY CORNWALL.}

I Love all things the seasons bring, All buds that start, all birds that sing,

All leaves, from white to jet ; All the sweet words that Summer senes, When she recalls her flowery friends, But chief-the Violet ?

I love, how much I love the rose, On whose soft lips the South-wind blow, In pretty amorous threat;

The lily paler than the moon, The odorous wondrous world of June,

Yet more-the Violet !

She comes-the first, the fairest thing That Heaven upon the earth doth fling,

Ere Winter's star has set; She dwells behind her leafy screen. And gives, as angels give, unseen: So, love-the Violet!

What modest thoughts the Violet teaches, What gracious boons the Violet preaches, Bright maiden, ne'er forget! But learn, and love, and so depart, And sing thou, with thy wiser heart,
" Long live the Violet!" 


\section{FADED FLOWERS.}

BT MISS JETSBURY.

FADED flowers,

Sweet faded flowers,

Beauty and death

Have ruled your hours,

Ye woke in bloom but a morn ago,

And now are your blossoms in dust laid low.

But yesterday

With the breeze ye strove,

In the play of life,

In the pride of love;

To and fro swung each radiant head,

That now is drooping, and pale, and dead !

Delicate flower,

With the pearl-white bells,

No more shall dew-drop

Sleep in thy cells!

No more, rich rose, on thy heaving breast,

The honey-bee fold his wings to rest'

Fair myrtle-tree,

Thy blossoms lie low,

But green above them

Thy branches grow ;

Like a buried love, or a vanish' $d$ joy Link'd unto memories none destroy. 
Faded flowers,

Sweet faded flowers-

Fair frail records

Of Eden's bowers ;

In a world where sorrow and wror.g bear 8 way,

Why should ye linger ?-Away! away!

What were the emblems

Pride to stain,

Might ye your glorious

Crowns retain?

And what for the young heart, bow'd with grief, Were the rose ne'er seen with a wither'd loaf ?

Ye bloom to tell us

What once hath been;

What yet shall in heaven

Again be seen ;

Ye die, that man in his strength may learn,

How vain the hopes in his heart that burn.

Many in form,

And bright in hue!

I know your fate,

But the earth to strew, And my soul flies on to immortal bowers Where the heart and the rose are not faded flowere 


\section{THE ROSES.}

BY BOWRITG.

I SAW them once blowing,

While morning was glowing;

But now are their wither'd leaves strew'd o'er the ground,

For tempests to play on,

For cold worms to prey on,

The shame of the garden that triumphs around.

Their bnds which then flourish'd,

With dew-Arops were nourish'd,

Which turn'd into pearls as they fell fromon bigh .

Their hues are all banish'd,

Their fragrance all vanish'd,

Ere evening a shadow has cast from the sky.

I saw, too, whoie ranes

Of glories and graces

Thus open and blossom, but quickly decay;

And smiling and gladness,

In sorrow and sadness,

Ere life reach'd its twilight, fade dimly away.

Joy's light-hearted dances

And me.ody's glances, 
Are rays of a moment-are dying when born;

And pleasure's best dower

Is nought but a flower,

A vanishing dew-drop-a gem of the morn.

The bright eye is clouded,

Its brilliancy shrouded,

Our strength disappears, we are helpless and lone'

No reason avails us,

And intellect fails us ;

Life's spirit is wasted, and darkness comes on.

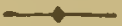

TO THE SNOW-D ROP.

BY BARRY CORNWALL.

PretTr firsting of the year !

Herald of the host of flowers,

Hast thou left my cavern drear,

In the hope of summer hours ?

Back unto my earthen bowers!

Back to thy warm world below,

Till the strength of suns and shower

Quell the now relentless snow !

Art still here?-Alive? and blithe?

Though the stormy night hath fled,

And the Frost hath pass'd his scy the

$O^{\prime}$ er hy small unshelter'd head. 
A h :-some lie amid the dead, (Many a giant stubborn tree,-

Many a plant, its spirits shed,)

That weve better nursed than thee'

What hath saved thee? Thou wast not

'Gainst the arrowy winter furr'd,--

Arm'd in scale-but all forgot

When the frozen winds were stirr'd.

Nature, who doth clothe the bird,

Should have hid thee in the earth,

Till the cuckoo's song was heard,

And the Spring let loose her mirth.

Nature-deep and mystic word,

Mighty mother, still unknown !

Thou didst sure the Snow-drop gird

With an armour all thine own !

Thou, who sent'st it forth alone

To the cold and sullen season,

(Like a thought at random thrown,)

Sent it thus for some grave reason!

If 'twere but to pierce the mind

With a single gentle thought,

Who shall deem thee harsh or blind?

Who that thou hast vainly wrought 8

Hoard the gentle virtue caught

From the Snow-drop-reader wise !

Good is good, wherever taught,

On the ground or in the skies ' 


\title{
TO THE JESSAMINE.
}

\author{
BY MISS JANE TAYLOI.
}

SweEt jessamine, long may thy elegant flower Breathe fragrance and solace for me:

And long thy green sprigs overshadow the bower Devoted to friendship and thee.

The eye that was dazzled where lilies and roses 'Their brilliant assemblage display' $d$, With grateful delight on thy verdure reposes, A tranquil and delicate shade.

But ah! what dejection that foliage expresses,

Which pensively droops on her breast!

The dew of the evening has laden her tresses,

And stands like a tear on her crest.

I'll watch by thy side through the gloom of the night

Impatient till morning appears :

No charm can awaken this heart to delight,

My jessamine, while thou art in tears.

But soon will the shadows of night be withdrawn Which ever in mercy are given; And thou shalt be cheer'd by the light of the morn, Ard fann'd by the breezes of heaven. 
And still map thy tranquil and delicate shade

Yield fraglance and colace to me;

For though all the flowers in my garden should fade,

My heart will repose upon thee.

\section{$\longrightarrow$ \\ ON A FADED VIOLET.}

BY SHELLEY.

THE odour from the flower is gone Which, like thy kisses, breathed on me ;

The colour from the flower is flown, Which glow'd of thee, and only thee!

I shrivel'd, lifeless, vacant form, It lies on my abandon'd breast, Ind mocks the heart, which yet is warm, With cold and silent rest.

I weep, - my tears revive it not ! I sigh,-it breathes no more on me;

Its mute and uncomplaining lot

In such as mine should be. 


\title{
DAWN, GENT'LE FLOWER.
}

\author{
BY BARRY CORNWALL.
}

DAwn, gentle flower,

From the morning earth! We will gaze and wonder

At thy wondrous birth !

Bloom, gentle flower!

Lover of the light,

Sought by wind and shower, Fondled by the night!

Fade, gentle flower!

All thy white leaves close;

Having shone thy beauty,

Time 'tis for repose.

Die, gentle flower,

In the silent sun!

So-all pangs are over,

All thy tasks are done?

Day hath no more glory,

Though he soars so ligh;

Thine is all man's story,

Live-and love-and dis! 


\section{THE LILY AND THE ROSE.}

\section{BY COWPER.}

'I'He nymph must lose her female friend

If more admired than she-

But where will fierce contention end,

If flowers can disagree?

Within the garden's peaceful scene

Appear'd two lovely foes,

Aspiring to the rank of queen,

The Lily and the Rose.

The Rose soon redden'd into rage,

And swelling with disdain,

Appeal'd to many a poet's page

To prove her right to reign.

The Lily's height bespoke command,

A fair imperial flower;

She seem'd design'd for Flora's hand,

The sceptre of her power.

This civil bickering and debate

The goddess chanced to hear;

And flew to save, ere yet too late,

The pidie of the parterre. 
THE POETRY OF FLOWER.

"Yours is," she said, " the noblest hue, And yours the statelier mien; And, till a third surpasses you,

Let each be deem'd a queen.'

Thus soothed and reconciled, both seek

The fairest British fair ;

The seat of empire is her cheek,

They reign united there.

\section{THE VIOLET.}

\section{BY SCOTT.}

ThE violet in her greenwood bower,

Where birchen boughs with hazels mir glo,

May boast herself the fairest flower,

In glen, or copse, or forest dingle.

Though fair her gems of azure hue,

Beneath the dew-drop's weight reclining,

I've seen an eye of lovelier blue,

More swcet through watery lustre shining.

The summer sun that dew shall dry,

Ere yet the day be past its morrow;

No longer in my false love's eye

Remain $d$ the tear of parting sorrow. 


\section{IHE DYING GIRL AND FLOWERS}

BEAR them not from grassy dells, Where wild bees have honey-cells, Not from where sweet water-sounds Thrill the greenwood to its bounds; Not to waste their scented breath On the silent room of Death!

Kindred to the breeze they are, And the glow-worm's emerald star, And the bird, whose song is free, And the many-whispering tree: $\mathrm{Oh}$ ! too deep a love, and fain, They would win to earth again.

Spread them not before the eyes, Closing fast on summer skies! Woo thou not the spirit back, From its lone and viewless track, With the bright things which have birth Wide o'er all the colour'd earth !

With the violet's breath would rise Thoughts too sad for her who dies; From the lily's pearl-cup shed, Dreams too sweet would haunt her bed; Dreams of youth-of spring-tine evesMusic-beauty-all she leaves! 
TAE POETRY CF FLOWERS.

Hush! 'tis thou that dreaming art,

Calmer is her gentle heart.

Yes! o'er fountain, vale, and grove,

Leaf and flower, hath gush'd her love

But that passion, deep and true,

Knows not of a last adieu.

Types of lovelier forms than these,

In their fragile mould she sees;

Shadows of yet richer things,

Born beside immortal springs,

Into fuller glory wrought,

Kindled by surpassing thought .

Therefore in the lily's leaf

She can read no word of grief;

O'er the woodbine she can dwel,

Murmuring not-Farewell ! farewell

And her dim yet speaking eye,

Greets the violet solemnly.

Therefore, once, and yet again,

Strew them o'er her bed of pain;

From her chamber take the gloom,

With a light and flush of bloom :

Bo should one depart, who goes

Where no death can touch the roso. 
THI POETRY OF FLOWERS,

\section{THE NIGHT-SHADE.}

\section{BY BARRY CORNWALL.}

TREAD aside from my starry bloom?

I am the nurse who feed the tomb

('The tomb, my chibd)

With dainties piled,

Until it grows strong as a tempest wild.

Trample not on a virgin flower!

I am the maid of the midnight hour;

I bear sweet sleep

To these who weep,

And lie on their eyelids dark and deep.

Tread not thou on my snaky eyes!

I am the worm that the weary prize,

'The Nile's soft asp,

That they strive to grasp,

And one that a queen has loved to clasp!

Pity me! I am she whom man

Hath hated since ever the world began;

I soothe his brain,

In the night of pain,

But at morning he waketh-and all is vain. 


\title{
THE LAY OF THE ROSE.
}

\author{
BY ELIZALETH B. BARRETT.
}

"Discordance that can accord ;

And accordance to discord."

i'he Romaunt of the Row

A rose once pass'd within

A garden, April-green,

In her loneness, in her loneness,

And the fairer for that oneness.

A white rose, delicate,

On a tall bough and straight,

Early comer, April comer,

Never waiting for the summer;

Whose pretty gestes did win

South winds to lut her ill, In her loneness, in her loneness, All the fairer for $t \mathrm{l}$ at oneness.

"For if I wait," said she,

"Till times for roses be,

For the musk rose, and the moss rosen Royal red and maiden blush rose, 
"What glory then for me,

In such a company?

Roses plenty, roses plenty,

And ono nightingale for twenty!

"Nay, let me in," said she,

"Before the rest are free,

In my loneness, in my lonenese,

All the fairer for that oneness.

" For I would lonely stand, Uplifting my white hand,

On a mission, on a mission,

To declare the coming vision.

"See mine, a holy heart,

To high ends set apart, -

All unmated, all unmated,

Because so consecrated.

"Upon which lifted sign,

What worship will be mine !

What addressing, what caressing,

What thanks, and praise and blessing '

"A wind-like joy will rush

Through every tree and bush,

Bending softly in affection,

And spontaneous benediction. 
THE POETRY OF FLOW ERS.

"Insects, that only may

Live in a sunbright ray,

T'o my whiteness, to my whiteness

Shall be drawn, as to a brightncss.

"And every moth and bee

Shall near me reverently,

Wheeling round me, wheeling o'er mo

Coronals of motioned glory.

"I ween the very skies

Will look down in surprise, When low on earth they see me, With my cloudy aspect dreamy.

"E'en nightingales shall flee Their woods for love of me, Singing sadly all the suntide, Never waiting for the moontide!

"Three larks shall leave a cloud To my whiter beauty vow'd, Singing gladly all the moontide, Never waiting for the suntide."

So praying did she win

South winds to let her in, In her loneness, in her loneness, And the fairer for that oneness. 
But out, alas, for her!

Nothing did minister

To her praises, to her praises, More than might unto a daisy's.

No tree nor bish was seen

To boast a perfect green,

Scarcely having, scarcely having One leaf broad enow for waving.

The little flies did crawl

Along the southern wall,

Faintly shifting, faintly shifting

Wings scarce strong enow for liftins.

The nightingale did please

To loiter beyond seas,

Guess him in the happy islands,

Hearing music from the silence.

The lark too high or low,

Did haply miss her so-

With his crest down in the gorses,

And his song in the star-courses !

Only the bee, forsooth, Came in the place of bothDoing honour, doing honour, T'o the honey-dews upon her. 
THE POETHY OF FLOWERS.

The skies look'd coldly down

As on a royal crown;

Then, drop by drop, at leisure,

Began to rain for pleasure.

Whereat the earth did seem

To waken from a dream,

Winter frozen, winter frozen,

Her anguish eyes unclosing.

Said to the rose, "Ha, Snow!

And art thou fallen so?

Thou who wert enthronéd stately

Along my mountains lately.

"Holla, thou world-wide snow

And art thou wasted so?

With a little bough to catch thee

And a little bee to watch thee?"

Poor rose, to be nisknown!

Would she had ne'er been blown,

In her loneness, in her loneness,

All the sadder for that oneness. .

Some words she tried to say,

Some sigh-ah, well away!

But the passion did o'ercome her, And the fair frail leaves dropn'd from ser. 
Dropp'd from her, fair and mute,

Close to a poet's foot,

Who beheld them, smiling lowly,

As at something sad yet holy:

Said "Verily and thus,

So chanceth e'er with us,

Poets, ringing sweetest snatches,

While deaf did men keep the watchen

"Saunting to come before

Our own age evermore,

In a loneness, in a loneness,

And the nobler for that oneness.

"But if alone we be

Where is our empiry?

And if none can reach our stature

Who will mate our lofty nature ?

"What bell will yield a tone

Saving in the air alone?

If no brazen clapper bringing,

Who can bear the chimêd ringing I

"What angel but would seem

To sensual eyes glent.dim ?

And without assimilation,

Vain is interpenetration! 
THE POETRY OF FLOWERS,

"Alas ! what can we do,

The rose and poet too,

Who both antedate our mission

In an unprepared season?

"Drop leaf-be silent song-

Cold things we came among!

We must warm them, we must warm them

Ere we even hope to charm them.

"Howbeit," here his face

Highten'd around the place,

So to mark the outward turning

Of his spirit's inward burning.

"Something it is to hold

In God's worlds manifold,

First reveal'd to creatures duty,

A new form of His mild beauty.

"Whether that form respect

The sense or intellect, Holy $r$ sst in soul or pleasance, The clief Beauty's sign of presence.

"Holy in me and thee, Ruse fallen from the tree, 'Though the world stand dumb around us, All unable to expound us, 
"Though none us deign to bless,

Blessed are we natheless;

Blessed age and consecrated

In that, Rose, we were created !

"Oh, shame to poet's lays,

Sung for the dole of praise-

Hoarsely sung upon the highway,

With an "obolum da milie!"

"Shame! shame to poet's soul Pining for such a dole,

When heaven-called to inherit

The high throne oi his own spirit?

"Sit still upon your thrones,

O ye poetic ones!

And if, sooth, the world decry you.

Why, let that world pass by you!

"Ye to yourselves suffice,

Without its flatteries;

Self-contcntedly approve you

Unto Him who sits above you.

"In prayers that upwarc mount, Like to a sunned fount, And, in gushing back upon you, Bring the music they have won you! 
THE POETRY OL FIOW RRS,

"In thanks for all the good

By poets understood-

For the sound of seraphs moving

Through the hidden depths of loving !

"For sights of things away, Through fissures of the clay,-

Promised things, which shall be given And sung ever up in heaven!

"For life, so lonely vain,

For death, which breaks the chain,For this sense of present sweetness, And this yearning to cornpleteness!' 


\section{EMBLEMS OF FLOWERS}

\section{BY BURNS.}

Apown winding Nith I did wander, To mark the sweet flowers as they spring : Adown winding Nith $I$ did wander.

of Phillis to muse and to sing.

The daisy amused my fond fancy,

So artless, so simple, so wild; 'Thou emblem, sair I. o' my Phillis.

For she is simplicity's child.

The rose-bud's the blush o' my cnarmor.

Her sweet balmy lip when 'tis prest:

How fair and how pure is the lily,

But fairer and purer her breast.

Yon knot of gay flowers in the arbour, They ne'er wi' my Phillis can vie:

Her breath is the breath of the woodbine, Its dew-drop o' diamond her eye.

Her voice is the song of the morning That wakes through the green-spreading grove When Phobus peeps over the mountains.

On mueic, and pleasure, and love. 
But beauty how frail and how fleeting, The bloom of a fine summer's day! While worth in the Inind o' my Phillis Will flourish without a decay.

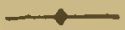

\section{THE OR A NGE•B O U G H.}

BY MRS. HEMANS.

Or ! bring me one sweet Orange-bough, To fan my cheek, to cool my brow; One bough, with pearly blossoms drest, And bind it, Mother! on my breast!

Go seek the grove along the shore, Whose odours I must breathe no more, The grove where every scented tree Thrills to the deep voice of the sea.

Oh! Love's fond sighs, and fervent prayer And wild farewell, are lingering there, Each leaf's light whisper hath a tone, My faint heart, even in death, would own.

Then bear me thence one bough, to shed Life's parting sweetness round my head, And bind it Mother! on my breast

When I am laid in lonely rest. 


\title{
TO THE NARCISSUS
}

\author{
BY BEN JONSON.
}

ARrse, and speak thy sorrows, Echo, rise ; Here, by this fountain, where thy love did pine, Whose memory lives fresh to vulgar fame, Shrined in this yellow flower, that bears his name,

\section{ECHO.}

His name revives, and lifts me up from earth ;See, see, the mourning fount, whose springs weep yet

Th' untimely fate of that too beauteous boy, That trophy of self-love, and spoil of nature, Who (now transform'd into this drooping flower) Hangs the repentant head back from the stream; As if it wish'd-would I had never look'd In such a flattering mirror! O, Narcissus ! Thou that wast once (and yet art) my Narcissue Had Echo but been private with ihy thoughts, She would have dropt away herself in tears, Till she had all turn'd waste, that in her (As in a true glass) thou mightst have gazed, And seen thy beauties by more kind reflection, But self-love never yet could look on truth, But with blear'd beams; slick flattery and sho Are twin-born sisters, and do mix their eyes, As if you sever one, the other dies. 
Why did the gods give thee a heavenly form And earthly thoughts to make thee froud of it 1 Why do I ask? 'Tis now the known disease That beauty hath, to bear too deep a sense Of her own self-conceived excellence. Oh hadst thou known the worth of Heaven's riah gift,

Thou wouldst have turn'd it to a truer use, And not (with starved and covetous ignorance) Pinod in continual eyeing that bright gem, The glance whereof to others had been more Than to thy famish'd mind the wide world's stora.

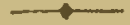 \\ THE HAREBELL. \\ BY SCOTT.}

"For me," - she stoop'd, and looking rouna, Pluck'd a blue harebell from the ground,-"For me, whose memory scarce conveys An image of more splendid days, This little flower, that loves the lea, May well my simple emblem be ; It drinks heaven's dew, blithe as the rose 'That in the king's own garden grows; And when I place it in my hair, Allan, a bard is bound to swear He ne'er saw coronet sc fair." 


\title{
THE POETRY OF FLOWERS. \\ SWEET LAVENDER.
}

\author{
BY MISS STRICKLAND.
}

SWEET lavender! I love thy flower

Of meek and modest blue,

Which meets the morn and evening hour

The storm, the sunshine, and the shower,

And changeth not its hue.

In cottage-maid's parterre thou'rt seen,

In simple touching grace;

And in the garden of the queen,

'Midst costly plants and blossoms sheen,

Thou also hast a place.

The rose, with bright and peerless blons

Attracted many eyes;

But while her glories and perfume

Expire before brief summer's doom,

Thy fragrance never dies.

Thou art not like the fickle train

Our adverse fatcs estrange ;

Who, in the day of grief and pain,

Are found deceitful, light, and vain,

For thou dost never change. 
TZE POETRY OF FLOWERS.

But thou art cmblem of the friend,

Who, whatsoe'er our lot,

The balm of faithful love will lend

And, true and constant to the end,

May die, but alters not.

\section{$\longrightarrow$ \\ THE HALF-BLOWN ROSE.}

\section{BY DANIEL.}

Look, now, now we esteem the half-blown rose.

The image of thy blush and summer's honour;

Whilst yet her tender bud doth undisclose

That full of beauty time bestows upon her.

No sooner spreads her glories to the air,

But straight her wide-blown pomp comes to decline ;

She then is scorn'd that late adorn'd the fair ;

So fade the roses of those cheeks of thine.

No April can revive thy wither'd flowers,

Whose springing grace adorns thy glory now ;

Swift, speedy time, feather'd with flying hours,

Dissolves the beauty of the fairest brow:

Then do not thou such treasure waste in vain, But love now whilst thou mayst be loved again. 


\section{TO THE DAIS Y.}

BI WORDSWORII,

Is youth from rock to rock I wen'

From hill to hill in discontent

Of pleasure high and turbulent, Most pleased when most uneasy;

But now my own delights I make,

My thirst at every rill can slake, And nature's love of thee partake,

Her much-loved daisy!

Thee winter in the garland wears

That thinly decks his few gray hairs

Spring parts the clouds with softest air

That she may sun thee;

Whole summcr-fields are thine by right;

And Autumn, melancholy wight

Doth in thy crimson head delight

When rains are on thee.

Be violets in their secret mews

The flowers the wanton zephyrs choose

Proud be the rose, with rains and dewe

Her head impearling ; 
TUE POETRY OF FLOWEKS.

Thou livest with less ambitious aim, Yet hast not gone without thy flame; Thou art indeed, by many a claim, The poet's darling.

If to a rock from rains we fly, Or, some bright day of April sky, Imprison'd by hot sunshine lie Near the green holly, And wearily at length should fare; He needs but look about, and there Thou art ! - a friend at hand, to scare Hiś melancholy.

A hundred times, by rock or bower, Ere thus I have lain couch'd an hour, Have I derived from thy sweet powe;

Some apprehension;

Some steady love; some brief delight, Some memory that had taken flight; Some chime or fancy wrong or right;

Or strong invention.

If stately passions in me burn, And one chance look to thee should turn I drink out of an humble urn A lowlier pleasure ; 'I'he hornely sympathy that heeds The common life, our nature breeds;

$A$ wisdoin titted to the needs of hearts at leisure. 
Fresh smitten by thy morning ray,

When thou art up, alert and gay, Then, cheerful flower! my spirits play

With kindred gladness:

And when, at dusk, by dews opprest, 'Thou sink'st, the image of thy rest Hath often eased my pensive breast Of careful sadness.

And all day long I number yet, All seasons through, another debt, Which I, wherever thou art met, To thee am owing;

An instinct call it, a blind senseA happy, genial influence, Coming one knows not how, nor whenee, Nor whither going.

Child of the year! that round dost run Thy pleasant course, - when day's begun, As ready to salute the sun

As lark or leveret,

Thy long-lost praise* thou shalt regain;

$\mathrm{N}$ or be less dear to future men

Than in old time; - thou not in vain

Art nature's favourite.

- see, In Chaucer and the elder poe:s, the honour. brinerly paid to this flower. 
THE POETRY OF FLOWERS.

\section{LOVE'S WREATH.}

BY MOORE.

W men J Jove was a child, and went idling round Among flowers the whole summer's day, One morn in the valley a bower he found, So sweet, it allured him to stay.

Q'erhead from the trees hung a garland fair, A fountain ran darkly beneath ;

"Twas Pleasure that hung the bright flowero uf there,

Love knew it and jump'd at the wreath.

But Love did not know-and at his weak years, What urchin was likely to know ?-

That sorrow had made of her own salt tears, That fountain which murmur'd below.

He caught at the wreath, but with too much haste As boys when impatient will do ; It fell in those waters of briny taste, And the flowers were all wet through.

Yet this is the wreath he wears night and di: ; And though it all sunny appears

With Pleasure's own lustre, each leaf, they way, Still tastes of the fountain $0^{c}$ tears. 


\section{TO A CROCUS.*}

\section{B I BER NARD BARTON.}

WELCOME, wild harbinger of spring !

To this small nook of earth;

Feeling and fancy fondly cling

Round thoughts which owe their birth

To thee, and to the humble spot

Where chance has fix'd thy lowly lot.

To thee, -for thy rich golden bloom,

Like heaven's fair bow on high,

Portends, amid surrounding gloom,

'That brighter hours draw nigh,

When blossoms of more varied dyes

Shall ope their tints to warmer skies.

Yet not the lily, nor the rose,

Though fairer far they be,

Can more delightful thoughte disclosn

Than I derive from thee:

The eye their beauty may prefe: ;

The heart is thy interpreter!

Methinks in hy fair flower is seen,

By those whose fancies roam,

- E $_{2}$ wing up and blossoming beneath 2 wall . Cowet 
An emblem of that leaf of green

The faithful dove brought home, When o'er the world of waters dark Were driven the inmatos of the ark.

'That leaf betoken'd freedom nigh To mournful captives there; Thy flower foretells a sunnier sky, And chides the dark despair By winter's chilling influence flung $O$ 'er spirits sunk, and nerves unstrung،

And sweetly has kind nature's hand Assign'd thy dwelling-place

Beneath a flower whose blooms expand, With fond congenial grace On many a desolated pile, Bright'ning decay with beauty's smile.

Chine is the flower of Hope, whose nue Is bright with coming joy ; whe wall-flower's that of faith, too true For ruin to destroy ;

And where, O ! where should hopo apspring But under faith's protecting wing. 


\section{ARRANGEMENTS OF A BOUQUET.}

\section{BY NICHOLAS DRAYTON.}

Here damask roses, white and red, Out of my lap first take I, Which still shall run along the thread My chiefest flower this make I.

Amongst these roses in a row, Next place I pinks in plenty, These double pansies then for show, And will not this be dainty?

The pretty pansy then I'll tie Like stones some chain inchasing; And next to them, their near ally, The purple violet placing.

The curious choice clove. July flower, Whose kind hight the carnation, For siveetness of most sovereign power. Shall help my wreath to fashion,

Whose sundry colours of one kınd, First from one root derived, Them in their several suits I'll bind: My garland so contrived. 
A course of cowslips then I'i stick, And here and there (though sparely) The pleasant primrose down I'll prick, Like pearls that will show rarely;

Then with these marigolds I'll make My garland somewhat swelling, These honcysuckles then I'll take, Whose sweets shall help their smelling.

The lily and the fleur-de-lis, For colour much contending, For that I them do only prize, They are but poor in scenting;

The daffodil most dainty is, To match with these in meetness; The columbine compared to this, All much alike for sweetness.

These in their natures only are Fit to cmboss the border, Therefore I'll take especial care To place them in their order:

Sweet-williams, campions, sofs-ill-wine, One by another neatly: Thus have I made this wreath of mirie, And funished it featly. 


\section{ON PLANTING A TULIP-ROOT.}

BY MONTGOMERY.

Here lies a bulb the child of earth, Buried alive beneath the clod, Ere long to spring, by second birth, A new and nobler work of God.

'Tis said that microscopic power

Might through his swaddling folds descry

The infant image of the flower,

Too exquisite to meet the eye.

This vernal suns and rain will swell,

Till from its dark abodc it pcep,

Like Venus rising from her shell,

Amidst the spring-tide of the deep

Two shapely leaves will first unfold; Then, on a smooth, elastic stem, The verdant bud shall turn to gold, And open in a diadem.

Not one of Flora's brilliant race

A form more perfect can display ! Art could not feign more simple prace

Nor Nature take a line awav. 
I et, rich as morn, of many a hue, When flushing clouds througl darkness strike T'he T'ulip's petals shine in dew

All beautiful, but none alike.

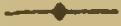 \\ TO BLOSSOMS.}

BY HERRICE.

FaIr pledges of a fruitful tree,

Why do ye fall so fast?

Your date is not so past

But you may stay here yet awhile,

To bluslı and gently smile,

And go at last.

What! were ye born to be

An hour or half's delight,

And so to bid good-night?

Twas pity nature brought ye forth

Merely tc show your worth,

And lose you quite.

But ye are lovely leaves, where we

May read how soon things have

Their end, though ne'er so brave:

And after they have shown their pride.

Like you, awhile, they glide

Into the grave. 


\section{A COMPARISON.}

\section{BY J. H. WIFFEN.}

-As yon flower, with hyacinthine bells, Playful as light, which shiver'd by my tread, Is turn'd to dust and darkness-to all else It is as though it was not; swiftly sped Spoil o'er its bruised buds which blossomed A blending of all sweetness-what now ? A few years hence, and over this bent head, Dashing all life and gladness from the brow, The scythe of Time shall pass, and Ruin's silen blough.

\section{But the Spring,}

Fair as Aurora in her purple cloud,

Descends and wakens in their slumbering, Life from the ashes, beauty from the shroud, And speaks of immortality aloud

To mourning man; and thus the flower I trod

To its maternal dust shall issue proud

Ofits new birth, and on a greener sod

Buw to the dil ying winds $--a$ sign to mar froc Gor. 


\section{THE EARLY PRIMROSE.}

Aske me why I send you here This firstling of the infant year; Aske me why I send to you This primrose all bepearl'd with dew; I straight will whisper in your ears, The sweets of love are washt with tearen Aske me why this flow' $r$ doth show So yellow, green and sickly too; Aske me why the stalk is weak, And bending, yet it doth not break; I must tell you, these discover What doubts and fears are in a Lover.

\section{THE HOLLY.}

\section{BY SOUTHEY.}

O READER! hast thou ever stood to see

The holly tree?

The eye that contemplates it well perceive

Its glossy leaves Order d by an Intelligence so wise:

As might corfound the Atheist's sophistries. 
Below a circling fence, its leaves are seen Wrinkled and keen ;

No grazing cattle through their prickly round Can reach to wound,

But as they grow where nothing is to fear, Smooth and unarm'd the pointless leaves appear

\section{NARCISSUS.}

\section{BY GRAY.}

Here young Narcissus o'er the fountain stood, And viewed his image in the crystal flood; The crystal flood reflects his lovely charms, And the pleased image strives to meet his arms. No nymph his inexperienced breast subdued, Echo in vain the flying boy pursued.

Himself alone the foolish youth admires, And with fond look the smiling shade desires, O'er the smooth lake with fruitless tears ho grieves:

His spreading fingers shoot in verdant leaves: Through his pale veins green sap now gently flowe. And in a short-lived flower his beauty blows. Let vain Narcissus warn each female breast That beauty's but a transient good at best; Like flowers, it withers with th' advancing year, And age, lik6 winter, robs the blooming fair. 
SHE POETRY OF FLOW EHS.

\section{ANACREON TO THE ROSE.}

W GILE we invoke the wreathcd spring,

Kesplendent Rose! to thee we'll sing,

Resplendent Rose! the flower of flowara,

Whose breath perfumes Olympus' bowerm,

Whose virgin blush, of chasten'd dye,

Enchants so much our mortal eye,

Oft has the poet's magic tongue

The Rose's fair luxuriance sung ;

And long the Muses, heavenly maids

Have rear' $d$ it in their tuneful shades,

When, at the early glance of morn,

It sleeps upon the glittering thorn,

'Tis sweet to dare the tangled fence,

To cull the timid floweret thence,

And wipe, with tender hand, away

The tear that on its blushes lay!

'Tis sweet to hold the infant stems,

Yet dropping with Aurora's gems,

And fresh inhale the spicy sighs

That from the weeping buds arise.

When revel reigns, when mirth is high

And Bacchus beams in every eye,

Our rosy fillets scent exhale,

Ind fill with balm the fainting gale!

Oh, there is nought in nature bright,

Where Ruses do not shed their light " 
Where morning paints the orient skies, Her fingers burn with roseate dyes ? And when, at length, with pale decline, Its florid bcauties fade and pine, Sweet as in youth its balmy breath Diffuses odour e'en in death!

$O$, whence could such a plant have sprung 1

Attend-for thus the tale is sung:-

When humid from the silvery stream, Effusing beauty's warmest beam, Venus appeared in flushing hues, Mellowed by Ocean's briny dews; When, in the starry courts above, The pregnant brain of mighty Jove Disclosed the nymph of azure glance! The nymph who shakes the martial lance! Then, then, in strange eventful hour, The earth produced an infant flower, Which sprung with blushing tinctures dress'd And wanton'd o'er its parent breast. T'he gods bcheld this brilliant birth, And hail'd the Rose, the boon of earth . With nectar drops, a ruby tide, The sweetly orient buds they dyed, And bade them bloom, the flowers divine Of him who sheds the teeming viru ; And bade them on the spangled thoen Exprnd their bosoms to the morn 


\title{
THB POETRY OF FLOWERS. \\ DECISION OF THE FLOWER.
}

\author{
BY L. E. LANDON.
}

AND with scarlet poppies, around like a bower The maiden found her mystic flower.

"Now, gentle flower, I pray thee tell

If my lover loves me, and loves me well:

So may the fall of the morning dew

Keep the sun from fading thy tender blue,

Now I number the leaves for my lot-

He loves not-he loves me-he loves me not

He loves me-yes, thou last leaf, yes-

I'll pluck thee not for the last sweet guess !

He loves me!"-_Yes," a dear voice sigh'd And her lover stands by Margaret's side.

\section{THE SNOW-D ROP.}

\section{BY MARY ROBINSON.}

Tue snowdrop, Winter's timid child, Awakes to life, bedew'd with tears, And flings around its fragrance mild; And, where no rival flowerets bloom, Amidst the bare and chilling gloom,

A beauteous gem appears. 
All weak and wan with head inclined, I.ts parent breast the drifted snow, It trembles, while the ruthless wind Bends its slim form; the tempest lowers, Its emcrald eye drops crystal showers On its cold bed below.

Where'er I find thee, gentle flower, Thou still art sweet and dear to me' For I have known the cheerless hour, Have seen the sunbeams cold and pale, Have felt the chilling wintry gale, And wept and shrunk, like thee!

\section{DAFFODILS.}

FAIR Daffodils, we weep to see

You haste away so soon;

As yet the early rising sun

Has not attained his noon:

Stay, stay

Until the hastening day

Has run

But to the even-song, And, having pray'd logether, wo

Will go wi'h you along. 
We have short time to stay as ye,

We have as fleet a spring,

As quick a growth to meet decay

As you or any thing;

We die

As your hours do, and dry

Away,

like to the summer's rain,

Or as the pearls of morning' 3 dew,

$\mathrm{Ne}$ 'er to be found again.

\section{THE SHEPHERD TO THE FLOWERS.}

\section{BI SIR WALTER RÁLEIGH.}

SWEET violets, love's paradise, tha spread

Your gracious odours, which you, couched, bear

Within your paly faces,

Upon the gentle wing of some calm.breathing wind,

That plays amidst the plain!

If, by the favour of propitious stars, you gain, \$uch grace as in my lady's bosom place to find,

Be proud to touch those places:

And when her warmth your moisture forth doth wear,

Whereby her dainty parts are sweetly fed, 
You, honours of the flowry meads, I nray,

You pretty daughters of the earth and sun, With mild and seemly breathing straight display

My bitter sighs, that have my heart undone'

\section{HEA R T'S.EA SE.}

BY SHAKSPEARE.

\section{I $8 \mathbf{A} \boldsymbol{w}$,}

Flying between the cold moon and the earth, Cupid all arm'd; a certain aim he took At a fair vestal throned in the west. And loosed his love-shaft smartlv from his bow, As it should pierce a hundred thousand hearts. But I might see young Cupid's fiery shaft Quench'd in the chaste beams of the wat'ry moon And the imperial vot'ress passed on, In maiden meditation, fancy-free.

Yet marked I where the bolt of Cupid fell: It fell upon a little western flower, Before milk-white, now purple with love's wouna, And maidens call it Love in Idleness. The juice of it, on sleeping eyelids laid, Will make a man or woman madiy doto Upon the next live creature that $i$. sees. 


\section{'THE SCARLET GERANIUM.}

I will not sing the mossy rose, The jasmine sweet, or lily fair, The tints the rich carnation shows, The stock's sweet scent that fills the air.

Full many a bard has sung their praise In metres smooth, and polished line; A simple flower and humbler lays May best befit a pen like mine.

There is a small but lovely flower, With crimson star and calyx brown, On pathway side, beneath the bower, By Nature's hand profusely strown.

Inquire you when this flowernt springs ?When Nature wakes to mirth and love, When all her fragrance summer flings, When latest autumn chills the grove.

Like the sweet bird whose name it bears, 'Midst falling leaves and fading flowers, The passing traveller it cheers, In shorten"d days and darksome hourm. 
And, should you ask me where it blow

I answer, on the mountains bare, High on the tufted rock it grows, In lonely glens or meadows fair.

It blooms amidst those flowery dales Where winding Aire pursues its coureo: It smiles upon the craggy fells That rise around its lofty source.

There are its rosy petals shown, 'Midst curious forms and mosses rare, Imbedded in the dark gray stone, When not another flower is there.

Oh ! emblem of that stcadfast mind Which, through the varying scenes of $\mathrm{Le}_{4}$ By genuine piety refined, Holds on its way 'midst noise and strife.

Whough dark the impending tempest lower, The path of beauty it espies,

Calm 'midst the whirlwind and the shower, Thankful when brighter hours arise.

Oh! could our darken'd minds discern In thy sweet form this lesson plain, Could we it practically learn, Herb Robert would no: bloom in vain. 


\section{THE HELIOTROPE.}

Trere is a flower, whese modest eye Is turn'd wilh looks of light and love, Who breathes her softest, sweetest sigh,

Whene'er the sun is bright above.

Let clouds obscure, or darkness veil,

Her fond idolatry is fled;

Her sighs no more their sweets exhale,

The loving eye is cold and dead.

Canst thou not trace a moral here,

False flatterer of the prosperous hour 1

Let but an adverse cloud appear,

And thou art faithless as the flower.

\section{ARMOUR OF THE ROSE.}

YodNe Love, rambling through the waod,

Found me in my solitude,

Bright with dew and freshly blown,

And trembling to the Zephyr's sighs;

But as he stoop'd to gaze upon

The living gem with raptured eyes,

It chanced a bee was busy there,

Searching for its fragrant fare • 
And, Cupid, stooping too, to sip, The angry insect stung his lip :

And, gushing from the ambrosial sell, One bright drop on my bosom fell. Weeping, to his mother he Told the tale of treachery, And she her vengeful boy to please, Strung his bow with captive bees, But placed upon my slender stem The poisoned sting she plucked from thom s And none since that eventful morn Have found the flower without a thorn.

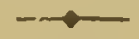

THE FORGET-ME-NOT.

Nor on the mountain's shelving side, Nor in the cultivated ground, Nor in the garden's painted pride, The flower I seek is found.

Where Time on sorrow's page of gliom Has fix'd its envious lot, Or swept the record from the tomb, It says, Forget-me-not.

And this is still the loveliest flower, The fairest of the fair, Of all that deck my lady's bower, Or bind her floating hair. 
THE POETRY UF PIOWERS.

\section{FIELD LEAVES.}

\section{BY ELIZABETH OAK SMITH.}

ThE tender violets bent in smiles

To the elves that sported nigh, Tossing the drops of fragrant dew

To scent the evening sky.

They kiss'd the rose in love and mirth, And its petals fairer grew;

A snower of pearly dust they brought And over the lily threw.

I saw one dainty creature crown The tulip's painted cup,

And bless with one soft kiss the urn, Then fold its petals up.

A finger rock'd the young pird's nest, As high on a brarch it hung, While the gleaming night dew rattled down Where the old dry leaf was f.ung 


\section{(ON THE INI)IAN-JASMINE FLOWER. BY RYAN.}

How lovelily the jasmine flower

Blooms far from man's observing eyes ;

And ilaving liveä its litile lour,

There withers, 一there sequester' $d$ dies!

Though faded, yet 'tis not forgot;

A rich perfume, time cannot sever,

Lingers in that unfriended spot,

And decks the jasmine's grave for ever.

Thus, thus should man, who seeks to soar

On learning's wings to fame's bright sky,

Far from his fellows seek that lore,

Unheeded live, sequester'd die.

Thus, like the jasmine, when he's fled,

Fame's rich perfume will ever keep,

Ling'ring around the faded dead,

As saints that watch some infant's sleep. 


\title{
THE EVENING PRIMROSE.
}

\author{
BY BERNARD BARTON.
}

FArr flower, that shunn'st the glare of dar, Yet lovest to open, meekly bold. To evening hues of sober gray, 'Thy cup of paly gold :

Be thine the offering, owing long, To thee, and to this pensive hour. Of the brief tributary song, Though transient as thy flower.

I love to watch at silent eve Thy scatter'd blossoms' lonely light : And have my inmost heart receivo The influence of that sight.

I love, at such an hour, to mark, Their beauty greet the light breeze chill, And shine, 'mid shadows gathering dark, The garden's glory still.

For such, 'tis sweet to think the while, When cares and griefs the breast invade In friendship's animating sinile, In sorrow's dark'ning shade. 
Thus it bursts forth like thy pale cup, Glist'ning amid its dewy tears, And bears the sinking spirit up Amid its chilling fears;

But still more animating far, If meek religion's eye may trace, Even in thy glimm'ring earth-born star The holier hope of grace!

The hope that, as thy beauteous bloon Expands to glad the close of day, Bo through the shadows of the tomb May break forth mercy' roj. 


\section{TO AN EARLY PRIMROSE}

BY H. K. WHITE.

MILD offspring of a dark and sullen sire. Whose modest form, so delicately fine,

Was nursed in whirling storms,

And cradled in the wind.

Thee, when young Spring first question'd Winter's sway,

And dared the sturdy blusterer to the fight-

Thee on this bank he threw,

To mark his victory.

In this row vale, the promise of the year,

Serene thou openest to the nipping gale,

Unnoticed and alone,

Thy tender elegance.

So virtue blooms, brought forth amid the stcrms Of chill adversity, in some lone walk

Of life she rears her head,

Obscure and unobserved;

While every bleaching breeze that on her hlows, Chastens her spotless purity of breast,

And hardens her to bear

Serene the ills of life. 


\section{THE ROSE BUD,}

\section{BY KEBLE.}

W new nature tries her finest touch,

Weaving her vernal wreath,

Mark ye how close she veils her round.

Not to be traced by sight or sound,

Nor soil'd by ruder breath?

Whoever saw the earliest rose

First open her sweet breast?

Or, when the summer sun goes down,

The first, soft star in evening's crown

Light up her gleaming crest?

Fondly we seek the dawning bloom

On features wan and fair,-

The gazing eye no change can trace,

But look away a little space,

Then turn, and lo!'tis there.

But there's a sweeter flower than e'er

Blush'd on the rosy spray-

A brighter star, a richer bloom,

'Than e'er did western heaven illume

At close of summer day. 
'Tis love, the last best gift of hearon; Love gentle, holy, pure:

But tenderer than a dove: $s$ soft eye, The searcling sun, the open sky, She never could endure.

Even human love will shrink from sight Here in the coarse rude earth:

How then should rash intruding glance Break in upon her sacred trance

Who boasts a heavenly birth?

So still and secret is her growth, Ever the truest heart, Where deepest strikes her kindly root For hope or joy, for flower or fruit, Least known its happy part.

STod only, and good angels, look Behind the blissful screenAs when, triumphant o'er his woes, The Son of God, by moonlight rose, By ali but heaven unseen:

As when the Holy Maid beheld Her risen Son and Lord:

Thought has not colours half so tair That she to paint that hour may dare In silence best adored. 
The gracious dove, that brought from heaven The earnest of our bliss,

Of many a chosen witness telling, On many a happy vision dwelling, Sings not a note of this.

So, truest image of the Christ, Old Israel's long-lost Son, What time, with sweet forgiving cheer, He call'd his conscious brethren near, Would weep with them alone.

He could not trust his melting soul But in his Maker's sightThen why should gentle hearts and true Bare to the rude world's withering view Their treasures of delight?

No-let the dainty rose awhile Her bashful fragrance hide-

Rend not her silken veil too soon, But leave her, in her own soft noon. To flourish and abides. 


\section{THE GARLA N D.}

\section{BY PRIOR.}

Tв pride of every grove I chose,

The violet sweet, the lily fair,

The dappled pink and blushing rose, To deck my charming Chloe's hair

At morn the nymph vouchsafed to place Upon her brow the various wreath; The flowers less blooming than her face, The scent less fragrant than her breatl

The flowers she wore along the day:

And every nymph and shepherd said, That in her hair they look'd more gray Than glowing in their native bed.

Undress'd at evening, when she found Their odours lost, their colours past; She changed her look, and on the ground Her garland and her eye she cast.

T'hat eye dropp' $d$ sense distinct and clear, As any Muse's tongue could speak, When from its lid a pearly tear

Ran trickling down her beauteous cheok. 15 
Dissembling what I knew too well, My love, my life, said I, explain This change of humour: pr'ythee tell: That falling tear-what does it mean

She sigh'd: she smiled: and to the flower Pointing, the lovely moralist saidSee, friend, in some few fleeting hours, See yonder, what a change is made.

Ah me! the blooming pride of May, And that of beauty, are but one: At morn both flourish bright and gay; Both fade at evening, pale, and gone.

At dawn poor Stella danced and sung, The amorous youth around her bow' d \& At night her fatal knell was rung; I saw, and kiss'd her in her shroud.

Buch as she is, who died to-day, Such I, alas! may be to-morrow: Go, Damon, bid the Muse display The justice of thy Chloe's sorrow. 
TEE POETRY OF FLOWERS.

\section{THE FIELD-FLOWER.}

\section{BY MONTGOMERT.}

There is a flower, a little flower, With silver crest and golden eye, That welcomes every changing hour, And weathers every sky.

The prouder beauties of the field In gay but quick succession shine, Ruce after race their honours yield, They flourish and decline.

But this small flower, to nature dea. While moon and stars their courses ran, Wreathes the whole circle of the year, Companion of the sun.

It smiles upon the lap of May, 'To sultry August spreads its charms, Iights pale October on his way, And twines December's arms.

The purple heath, and golden broom, On moory mountains catch the gale. O'er lawns the lily sheds perfume, The violet in the vale; 
But this bold floweret climbs the hil Hides in the forest, haunts the gke, Stays on the margin of the rill, Peeps round the fox's den.

Within the garden's cultured round It shares the sweet carnation's bed; And blooms in consecrated ground In honour of the dead.

The lambkin crops its crimson gew, The wild-bee murmurs on its breast The blue-fly bends its pensile stem, Light o'er the skylark's nest.

'Tis Flora's page:-in every place, In every season, fresh and fair, It opens with perennial grace, And blossoms every where.

On waste and woodland, rock and plair, Jts humble buds unheederl rise; The rose has but a summer reign, The daisy never dies. 
THE POETRY OF FLOWERS

TO THE SNOW-DROP.

\section{BY REBLE。}

'Tно first-born of the years' delight, Pride of the dewy glade,

In vernal green and virgin white, Thy vestal robes, array'd:

'Tis not because thy drooping form Sinks grateful on its nest, When chilly shades from gathering storm Affright thy tender breast;

Nor from yon river islet wild Beneath the willow spray, Where, like the ringlets of a child, Thou wear'st thy circle gay ;

'Tis not for these I love thee dear,Thy shy averted smiles

To fancy bode a joyous year One of life's fairy isles.

They twinkle to the wintry moon, And cheer the ungenial day, And tcll us all will glisten soon As green and bright as they. 
Is there a heart tha' loves the spring,

Their witness can refuse?

Yet mortals doubt; when angels bring

From heaven their Easter news:

When holy maids and matrons speak

Of Christ's forsaken bed,

And voices, that forbid to seek

The living 'mid the dead;

And when they say, "Turn, wandering hear

"Thy Lord is risen indeed,

Let pleasure go, put care apart, And to his presenee speed ;"

We smile in scorn ' and yet we know

They early sought the tomb,

Their hearts that now so freshly glow,

Lost in desponding glnom.

They who have sol.ght, nor hope to find,

Wear not so bright a glance:

They who have wi $n$ their earthly minà,

Less reverently advance.

But where, in gentle spirits, fear

And joy so duly meet.

These sure have seen the angels near,

And kiss'd the Sarour's feet. 
Iet the pastor's thankful eye

$T$ seir faltering tale disdain,

As un their lowly couch they lie,

Prisoners of want and pain.

guide us, when our faithless hearts From thee would start aloof, Where patience her sweet skill imparta Beneath some cottage roof:

Revive our dying fires to burn High as her anthems soar, And of our scholars let us learn Our own forgotten lore.

\section{COWSLIPS.}

\section{B Y MA R X HOWITT.}

$N_{A y}$, tell me not of Austral flowers, Or purple bells from Persia's bowers, The cowslip of this land of ours,

Is dearer far to me! This flower in other yeare I knew! I know the field wherein it grew, With violets white and violets blae, Beneath the garden tree. 
I never see these flowers but they Send back my memory, far away, To years long past, and many a day Else perish'd long ago!

They bring my childhood's years agan Our garden-fence, I see it plain, With ficaries like a golden rain Shower'd on the earth below.

A happy child, I leap, I run, And memories come back, one by one, Like swallows with the summer sun, To their old haunts of joy !

A happy child, once more I stand, With my kind sister, hand in hand, And hcar those toncs, so sweet, so bland, That never brought annoy!

I hear again my mother's wheel, Her hand upon my head I fecl; Her kiss, which every grief could hea, Is on my check even now; I see the dial overhead;

I see the porch o'er which was led, The pyracantha green and red, And jessamine's slender bough.

I see the garden-thicket's shade, Where all the summer long we play'd, And gardens set, and houses made, Our early work and late; 
Our little gardens, side by side, Each boider'd round with London prid Some six feet long, and three feet wide, To us a large estate!

The apple and the damson trees, The cottage shelter for our bees; I see them-and beyond all these, A something dearer still;

I see an eye serenely blue,

A cheek of girlhood's freshest hue,

A buoyant heart, a spirit true, Alike in good and ill.

Sweet sister, thou wert all to me, And I sufficient friend for thee : Where was a happier twain than we Who had no mate beside? Like wayside flowers in merry $\mathrm{May}_{\text {: }}$ Our pleasures round about us lay: A joyful morning had our day, Whate' $3^{*}$ sut ere betide! 


\section{H E A R T'S-EA SE.}

\section{BY MRS. SHERIDAN.}

Iv gardens oft a beauteous flower there grows, By vulgar eyes unnoticed and unseen; In sweet serenity it humbly blows, And rears its purple head to deck the green.

This flower, as nature's poet sweetly sings,

Was once milk-wlite, and heart's ease was it name,

Till wanton Cupid poised its roseate wings,

A vestal's sacred bosom to inflame.

With treacherous aim the god his arrow drew,

Which she with icy coldness did repel

Rebounding thence with featiery speed it flew, Till on this lonely flower, at last, it fell.

Heart's-ease no nure the wandering shepherc found ;

No more the nymphs its snowy form possess; Its white now changed to purple by love is wound, Hoart's-ease no more,-'tis love-in-idleness. 
THE POETRY OF FLOTERS.

\title{
TO THE SWE ET-BRIER。
}

\author{
BY J. G. C. BRAINARD.
}

OUR sweet autumnal western-scented wind Robs of its odours none so sweet a flower, In all the blooming waste it left behind, As that sweet-brier yields it; and the shower Wets not a rose that buds in beauty's bower One half so lovely; yet it grows along

The poor girl's pathway; by the poor man's door.

Such are the simple folks it dwells among; And humble as the bud, so humble be the song.

I love it, for it takes its untouch'd stand Not in the vase that sculptors decorate; Its sweetness all is of my native land; And e'en its fragrant leaf has not its mate Among the perfumes wnich the rich and great Bring from the odours of the spicy East. You love your flowers and plants and will you hate

The little four-leaved rose that I love best, That freshest will awake, and sweetest go to rest 1 


\title{
MOTHER'S DIRGE OVER HER CHILI)
}

\author{
BY D. M. MIOIR.
}

Brise me flowers all young and sweet That I may strew the winding-sheet, Where calm thou sleepest, baby fair, With roseless cheek and auburn hair.

Bring me the rosemary, whose breath Perfumed the wild and desert heath; The lily of the vale, which too, In silence and in beauty grew.

Bring cypress from some sunless spur, Bring me the blue forget-me-not; 'That I may strew them o'er thy bier, With long-drawn sigh and gushing tear

Ob, what upon this eartl doth prove So steadfast as a mother's love! $\mathrm{Oh}$, what on earth can bring relief Or solace to a mother's grief!

No more my baby shalt thou lie. Witl drowsy smiles and half-shut eyo. Pillow'd upon my fostering breast, Serenely sinking into rest! 
Thy grave must be thy cradle now ; The wild flowers o'er thy breast shall flow, While still my heart, all full of thee, In widow'd solitude shall be.

No taint of earth, no thought of sin, E'er dwelt thy stainless breast within, And God hath laid thee down to sleep, Like a pure pearl below the deep.

Yea! from mine arms thy soul hath flown Above, and found the heavenly throne, To joint that blest angelic ring, That aye around the altar sing.

I thought, when years had roll'd away, That thou wouldst be my age's stay; And often have I dream'd to see 'The boy-the youth-the man in thee'

But thou hast past ! for ever gone, To leave me childless and alone, Like Rachel frowning tear on tear. And looking not for comfort here!

Farewell, my child, the dews shall fall, At noon and evening, o'er thy pall; And daisies, when the vernal year Revives, upon thy turf appear. 
The earliest snow-drop there shall spring, And lark delight to fold his wing; And roses pale, and lilies fair, With perfume load the summer air!

Adieu, my babe! if life were long, 'This would be even a heavier song ; But years, like phantoms, quickly pass, They look to us from memory's glass.

Soon on death s couch shall I recline; Soon shall my head be laid with thine; And sunder'd spirits neet above, To live for evermore in love.

\section{THE ROSE.}

\section{TRANSLATED HIOM CAMOENB}

Jest like love is yonder rose :Heavenly fragrance round it throws, Yet tears its dewy leaves disclose, And in the midst of briers it blows;

\section{Just like Love.}

Cull'd to bloom upon the breast, Since rough thorns the stem invest, They must be gather'd with the rest, And with it to the heart be prest;

$$
\text { Just like Lovo. }
$$


And when the rude hands the twin buds sever They die, and they shall blossom never;

Yet the thorns be sharp as cver;

Just like Lovo

\section{"GO TO THE FOREST SHADE."}

BY MRS. HEMANS.

Go 0 the forest shade-

Seek thou the well known glade.

Where, heavy with sweet dew, the violets lie, Gleaming through moss-tufts deep,

Like dark eyes fill'd with sleep, And bathed in hues of summer's midnight sky.

Bring me their buds, to shed

Around my dying bed

A breath of May, and of the wood's repose;

For I in sooth depart

With a reluctant heart,

That fain would linger where the bright sun glown

Fain would I stay with thee-

Alas! this may not be,

Yet bring me still the gifts of happier houro!

Go where the fountain's breast

Catehes, in glassy rest,

The dim green light that pours through laural lowers. 
I know how sofily bright,

Stenp'd in that tender light,

The water-bilies tremule there e'en now;

Go to the pure stream's edge,

And from its whispering sedge

Bring me those flowers to cool my fever'd urow!

Then, as in hope's young days.

Track thou the antique maze

of the rich garden to its grassy mound;

There is a lone white rose,

Shedding, in sudden snows,

Its faint leaves o'er the enserald turf around.

Well knowest thou that fair tree-

A murmur of the bee

Dwells ever in the honey' $d$ lime above;

Bring me one pearly flower

Of all its clustering shower-

For on that spot we first reveal'd our love.

Gather one woodbine bough,

Then, from the lattice low

of the bowered cottage which I bade theo mark,

When by the hamlet last,

Through dim wood-lanes we pass'd,

While dews were glancing to the glow-worm'w spark. 
Haste! to my pillow bear

Those fragrant things and fair,

Thy hand no more may bind them uf at evo-

Yet shall their odour soft

One bright dream round me waft

Of life, youth, summer-all that I must leave!

And, oh ! if thou wouldst ask

Wherefore thy steps I task,

The grove, the stream, the hamlet vale to trace,

'l'is that some thought of me,

When I am gone, may be

The spirit bound to each familiar place.

I bid mine image dwell

(Oh! break not thou the spell!)

In the deep wood and by the fountain side;

Thou must not, my beloved!

Rove where we two have roved,

Porgetting her that in her spring.time died' 


\section{TO A JASMINE-TREE}

GRO WING IN THE COURT OF HAWORTH CASTIB

\section{BY LORD MORPETH.}

M $\nabla$ slight and slender jasmine-tree, That bloomest on my Border tower, Thou art more dearly loved by me, 'Than all the wealth of fairy bower. I ask not, while I near thee dwell, Arabia's spice or Syria's rose; Thy bright festoons inore freshly smell, Thy virgin white more freshly glows. My mild and winsome jasmine-tree, That climbest up the dark gray-wal'. Thy tiny flowerets seem in glee, Like silver spray-drops down to fall: Say, did they from their leaves thus peep, When mail'd moss-troopers rode the hill When helmed wardens paced the keep,

And bugles blew for Belted Will? My free and feathery jasnine-tree, Within the fragrance of thy breath, Yon dungeon grated to its key,

And the chain'd captive pined for death.

On Border fray, on feudal crime,

I dream not while I gaze on thee;

The chieftains of that stern old time

Cuald nc'er have loved a jasmine-tree. 


\section{APRIL FLOWERS.}

\section{RY BISHOP MANT.}

Nok, April, fail with scent and hue, To giace the lowlier blossoms new. Not only that, where weak and scant Peep'd forth the early primrose plant, Now shine profuse unnumber'd eyes, Like stars that stud the wintry skies; But that its sister cowslip's nigh, $W$ ith no unfriendly rivalry Of form and tint, and fragrant smells, $O$ 'er the green fields their yellow bells Unfold, bedropt with tawny red, And meekly bend the drooping head Not only that the fringed edge Of heath, or bank, or pathway hedge, Glows with the furze's golden bloom; But mingling now, the verdant broom With flowers of rival lustre deck'd, Uplifts its shapelier form erect. And there upon the sod below, Ground-ivy's purple blossoms show, Like helmet of crusader knight, Ita anthers' crosslike forms of wl ite: And lesser periwinkle's bloom, Like carpet of Damascus' loom, 
Pranks with bright blue the tissue wovo

Of verdant foliage; and above,

With milk-white flowers, whence soon shall sw

Rich fruitage, to the taste and smell

Pleasant alike, the strawberry weaves

Its coronets of three-fold leaves, In mazes through the sloping wood.

Nor wants there in her dreamy mood, What fancy's sportiveness may think

A cup, whence midnight elves might drink

Delicious drops of nectar'd dew,

While they their fairy sports pursue,

And roundelays by fount or rill-

The streak'd and chequer'd daffodil.

Nor wants there many a flower beside,

On holt, and hill, and meadow pied;

With pale green gloom the upright box,

And woodland crowfoot's golden locks;

And yellow cinquefoil's hairy trail ;

And saxifrage with peta! pale;

And purr.ie bilberry's globelike head;

And cranberry's bells of rosy red;

And creeping groundsel blue and bright;

And cranesbill's streaks of red and white,

On purple with soft leaves of down,

And golden tulip's turban'd crown,

Bweet scented on its bending stem;

And bright-eyed star of Bethlenem;

With those, the firstlings of their kind,

Which through the bosky thickets wind 
'Their tendrils, vetch, or pea, or tare, At random; and with many a pair Of leaflets green the brake embower, And many a Iendant-painted flower.

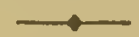

\section{FLOWERS.}

BY ELIZABETH OAK SMITH.

Each leaflet is a tiny scroll Inscribed with holy truth, A lesson that around the heart Should keep the dew of youth; Bright missals from angelic throngs In every by-way left

How were the earth of glory shorn Were it of flowers bereft!

T'hey tremble on the Alpine heights, The fissured rock they press,

The desert wild with heat and sand, Sharcs too their blessedness.

And wheresoe'er the weary heart Turns in its dim despair, T'he meek-eyed blossom upward looks, Inviting it to frayer ! 


\section{THE ORCHIS.}

\section{BY SNOW.}

SER, Delia, see this inage bright, Why starts my fair one at the sight ?

It mounts not on offensive wing,

Nor threats thy breast with angry sting ;

Admire, as close the insect lies,

Its thin-wrought plume and honey'd thighe

Whilst on this floweret's velvet breast,

It seems as though 'twere lull'd to rest.

Nor might its fairy wings unfold,

Enchain'd in aromatic gold.

Think not to set the captive free,

" $T$ is but the picture of a bee.

Yet wonder not that nature's power, Should paint an insect in a flower, And stoop to means that bear in part Resemblance to imperfect art.

Nature, who could that form inspire With strength and swiftness, life and fire, And bid it search each spicv vale, Where flowers their fragrant souls exhale; And labouring for the parent hive, With murmurs make the wild alive. For when in Parian stone we trace Some best remember'd form or face; 
TEE POETI.Y OF FLOWEBS.

Or see on radiant canvass rise

An imitative paradise;

And feel the warm affections glow,

Pleased at the pencil's mimic show ;

'Tis but obedience to the plan

From nature's birth opposed to man,

Who, lest her choicest sweets in vain

Should blossnm fer our thank!ess train;

Lest beauty pass unheeded by,

Like cloud upon the summer sky;

Lest memory of the brave and just,

Should sleep with them confined to dust ?

With leading hand the expedient proves,

And pairts for us tie form she lovea. 


\section{THE DAISY IN INDIA}

\section{BY JAMES MONTGOMERY.}

T'HRICE welcome, litıle English flower! Thy mother country's white and red, In rose or lily, till this hour Never to me such beauty spread: Transplanted from thy island bed, A treasure in a grain of earth, Strange as a spirit from the dead Thy embryo sprang to birtl

Thrice welcome, little English flower. Whose tribes beneath our native skies Shut close their leaves while vapours lower. But when the sun's gay beams arise, With unabash'd but modest eyes, Follow his motion to the west, Nor cease to gaze till daylight dies, Then fold themselves to rest.

Thrice welcome, little English flower. To this resplendent hemisphere, Where Flora's giant offspring tower In gorgeous liveries all the year; Thou, only thou, art little liere,

Like worth unfriended anc unknown, 
Yet to my British heart more dear Than all the torrid zone.

Thrice welcome, little English flower ! Of early scenes bcloved by me, While happy in my father's bower, Thou shalt the blithe memorial be; The fairy sports of infancy,

Youth's golden age, and manhood's prime, Home, country, kindred, friends, - with the Are mine in this far clime.

Thrice welcome, little English flower I'll rear thee with a trembling hand; $O$ for the April sun and shower, The sweet May-dews of that fair land, Where daisies, thick as star-light, stand In every walk! - that herc might shoot, Thy scions, and thy buds expand,
A hundred from one root!

Thrice welcome, little English flower!

To me the pledge of hope unseen: When sorrow would my soul o'erpower For joys that were, or might liave been, I'll call to mind, how-fresh and green1 saw thee waking from the dust; Then turn to heaven, with brow serene, And place in God my trust. 


\section{THE PRIMROSE OF THE ROCK.}

BY WORDSWORTH.

A Rock there is whose lonely front The passing traveller slights;

Yet there the glow-worms hang their lamps

Like stars, at various heights; And one coy primrose to that rock

The vernal breeze invites.

What hideous warfare hatlı been waged

What kingdoms overthrown,

Since first I spied that primrose tuft, And mark'd it for my own!

A lasting link in nature's chain

From highest heaven let down.

The flowers, still faithful to the stems,

Their fellowship renew ;

The stems are faithful to the root,

That worketh out of view ;

And to the rock the root adheres, In every fibre true.

Close clings to earth the living rock,

Though threatening still to fall;

The earth is constant to her sphere,

And God upliolds thern all: 
So bloonıs this lonely plant, nor dreads Her annual funeral.

Here closed the meditative strain;

But air breathed soft that day,

The hoary mountain heights were cheer'd,

The sunny vale look'd gay;

And to the primrose of the rock

I gave this after lay.

I sang-Let myriads of bright flowers,

Liks thee, in field and grove,

Revive unenvied;-mightier far,

Than tremblings that reprove

Our vernal tendencies to hope,

Is God's redeeming love ;

That love which changed-for wan disease

For sorrow that had bent,

O'er hopeless dust, for wither'd ago-

Their moral element,

A.nd turn'd the thistles of a curse

'To types beneficent.

Sin.blighted though we are, we too,

The reasoning sons of men,

From our oblivious winter call'd,

Shall rise and breathe again;

And in eternal summer-lose

Our threescore years and ten. 
To humbleness of heart descends

This prescience from on high,

The faith that elevates the just,

Before and when they die ;

And makes each soul a separate heaven,

A court for Deity.

THE ROSE.

\section{BY SPENSER.}

An! see the virgin rose, how sweetly sho Doth first peep forth with bashful modesty,

That fairer seems the less ye see her way!

Lo! see soon after, how more bold and free

Her bared bosom she doth broad display ;

Lo! see soon after, how she fades away ard falls

\section{INFANT SLUMBER.}

A воцу smile was on her lip, Whenever sleep was there,

She slept, as sleeps the blossom, uush'd Anid the silent air - E. OAK SMITH. 
TAE POETRY OF FLOWRRS.

\title{
THE VIOJET.
}

\author{
BY MISS L. E. LANDOF.
}

W

Love I this little flower?

Because its fragrant leaves are those

I loved in childhood's hour.

Though many a flower may win my praim

The violet has my love;

I did not pass my childish days

In garden or in grove.

My garden was the window-seat,

Upon whose edge was set

A little vase-the fair, the sweet-.

It was the violet.

It was my pleasure and my pride;-

How I did watch its growth .

For healih and bloom what plans I tried

And often injured both!

I placed it in the summer shower,

I placed it in the sun;

And ever at the evening hour,

My work seem'd half undono. 
The broad leaves spread, the small buds grow. How slow they seem'd to be! At last there came a tirige of blue, 'Twas worth the world to me!

At length the perfume fill' $d$ the room, Shed from their purple wreath; No flower has now so rich a bloom, Has now so sweet a breath.

I gather'd two or three-they seem'd Such rich gifts to bestow!

So precious in my sight, I deem'd That all must think them so.

Ah ! who is there but would be fain

To be a child once more ;

If future years could bring again

All that they brought before?

My heart's world has been lcng o' erthrown; It is no more of flowers;

Their bloom is pass'd, their breath is flown; Yet I recall those hours.

Let nature spread her loveliest,

By spring or summer nurst: Yet atill I love the violet berts

Because 1 lor ed it first. 


\section{FIELD FLOW E R.}

\section{BY CAMPBELI}

Y E field flowers! the gardens eclipse you, 'tis true, Yet, wildings of nature, I dote upon you, For ye waft me to summers of old, When the earth teem'd around me with fairy de. light,

And when daisies and buttercups gladden'd my sight,

Like treasures of silver and gold.

I love you for lulling me back into dreams

Of the blue Highland mountains and echoing streams,

And ot birchen glades breathing their balm, While the deer was seen glancing in sunshine remote,

And the deep mellow crush of the wood-pigeon . note

Made music that sweeten'd the caim.

Not a pastoral song has a pleasanter tune

Than ye speak to my heart, little wilciings of June:

Of old ruinous castles ye tell, Where I thought it delightful your beauties to find,

When the magic of nature first breathed on my mind,

And your blossoms wee nart of the sped. 
Fven now what affections the violet awakes ! What loved little islands, twice seen in thou lakes,

Can the wild water-lily restore!

What landscapes I read in the primrose's looks, And what pictures of nebbled and minnowy brooks,

In the vetches that tangled their shore !

Earth's cultureless buds, to my heart ye were dear,

Ere the fever of passion, or ague of fear,

Had scathed my existence's bloom;

Once I welcome you more, in life's passionles stage,

With the visions of youth to revisit my age, And I wish you to grow on my tomb. 


\title{
THE POETRY OF FLUVERS. \\ IN EASTERN LANDS.
}

\author{
BY.J. G. PERCIVAL.
}

IN Eastern lands they talk in flowers,

And they tell in a garland their loves and cares; Each blossom that blooms in their garden bowers, On its leaves a mystic language bears.

T'he rose is a sign of joy and love, Young blushing love in its carliest dawn; And the mildness that suits the gentle dove From the myrtle's snowy flower is drawn.

Innocence shines in the lily's bell,

Pure as the heart in its native heaven;

Fame's bright star and glory's sivell, By the glossy leaf of the bay are given.

The silent, soft, and humble heart

In the violet's hidden sweetness breathes; And the tender soul that cannot part,

A twine of cvergreen fondly wreathes.

The cypress that daily shades the grave,

Is sorrow that mourns her bitter lot, And faith that a thousand ills can brave

Speaks in thy blue leaves-forget-me-not.

Then gather a wreath from the gurden bower.

And tell the wish of thy heart in flowers. 


\section{THE HONEYSUCKLE.}

8X THE COUNTESS OF BLESSINGTOF,

SEE the honeysuckle twine

Round this casement:-'tis a shrine

Where the heart doth incense give,

And the pure affections live

In the mother's gentle breast

By her smiling infant press'd.

Blessed shrine! dear, blissful home !

Source whence happiness doth come!

Round by the cheerful hearth we mest

All things beauteous - all things swees

Every solace of man's life,

Mother, daughter,- sister,-wife !

England, isle of free and brave,

Circled by the Atlantic wave!

Though we seek the fairest land

That the south wind ever fann'd,

Yet we cannot hope to see

Homes so holy as in thee.

As the tortoise turns its head

Towards its native ocean-bed,

Howsoever far it be

From its own beloved sea,

Thus, dear Albion, evermore

Do we turn to scek thy shore" 
TaB POETRY CE FLOWERS.

TO A SNOW-DROP.

BY LANGHORNE.

Poers still, in graceful numbers, May the glowing roses choose; But the snow-drop's simple beauty Better suits an humble muse.

Earliest bud that decks the garden, Fairest of the fragrant race, First-born child of vernal Flora, Seeking mild thy lowly place;

Though no warm or murmuring zephyt

Fan thy leaves with balmy wing, Pleased we hail thee, spotless blossom, Herald of the infant spring.

Through the cold and cheerless season Soft thy tender form expands, Safe in unaspiring graces,

Foremost of the blooming bands.

White-robed flower, in lonely beauty, Rising from a wintry bed; ihilling winds, and blasts ungenial, Rudely threat'ning round thy head. 
Silv'ry bud, thy pensile foliage Seems the angry blasts to fear; Yet secure, thy tender texture Ornaments the rising year.

No warm tints, or vivid colouring, Paint thy bells with gaudy pride; Mildly charm'd we seck thy fragrancs Where no thorns insidious hide.

Tis not thine, with flaunting beauty, To attract the roving sight; Nature froin her varied wardrobe, Chose thy vest of purest white.

White as Jalls the fleecy shover, Thy soft form in sweetness grow:; Not more fair the valley's treasure, Not more sweet her lily blows.

Drooping harbinger of Flora, Simply are thy blossoms drest ; Artless as the gentle virtues Mansion'd in the blameless breast.

When to pure and timid virtue Friendship twines a votive wreath, $O^{\prime}$ er the fair seleeted yarland 'Lhou thy perfume soft shalt broathe. 
TIE POETRY CF FLOWBRS.

\section{TO THE PASSION-FLOWER.}

\section{BY BERNARD BARTON.}

IF Superstition's baneful art

First gave thy mystic name,

Reason, I trust, would steel my heart

Against its groundless claim;

But if, in fancy's pensive hour,

By grateful feelings stirr'd,

Her fond imaginative power

That name at first conferr'd-

Though lightly truth her flights may prize,

By wild vagary driven,

For once their blameless exercise

May surely be forgiven.

We roam the seas-give new-found isles

Some king's or conqueror's name:

We rear on earth triumphant piles

As meeds of earthly fame :-

We soar to heaven; and to outlive

Our life's contracted span,

Unto the glorious stars we give

The names of mortal man: 
Then may not one poor floweret's bloom

The holier memcry share

Of Him, who, to avert our doom,

Vouchsafed our sins to bear?

God dwelleth not in temples rear'd

By work of human hands,

Yet shrines august, by men revered

Are found in Christian lands.

And may not e'en a simple flower

Proclaim His glorious praise,

Whose fiat, only, had the power

Its form from earth to raise?

Then freely let thy hlossom ope

lts beauties-to recall

A scene which bids the humble bow

In Hiw who died for all ! 
THE POETRY OF FLOWERS.

\section{THE LILY OF THE VALLEY}

\section{BY BISHOR MANT.}

FAIr flower, that, lapt in lowly glade, Dost hide beneath the greenwood shade Than whom the vernal gale

None fairer wakes, on bank, or spray,

Our England's lily of the May,

Our lily of the vale !

Art thou that "Lily of the field,"

Which, when the Saviour sought to shield

The heart from blank despair,

He show'd to our mistrustful kind,

An emolem of the thoughtful mind

Of God's paternal care?

Not this. I trow ; for brighter shiro

To the warm skies of Palestine

Those children of the East :

There, when mild autumn's early rain

Descends on parch'd Esdrela's plain

And Tabor's oak-girt crest,

More frequent than the host of night, Those earth-born stars, as sages write,

Their brilliant disǩs unfold; 
Fit symbol of imperial state,

Their sceptre-seeming forms ela.e, And crowns of burnish'd gold.

But not the less, sweet spring-tide's flower,

Dost thou display the Maker's power, His skill and handy work,

Our western valleys' humbler child, Where, in green nook of woodland wild, Thy modest blossoms lurk.

What though nor care nor art be thine, The loom to ply, the thread to twine, Yet born to bloom and fade, Thee to a lovelier robe arrays, Than, e'en in Israel's brightest days, Her wealthiest kings array'd.

Of thy twin-leaves the embower'd screer, Which wraps thee in thy shroud of green Thy Eian-breathing smell;

Thy arch'd and purple-vested stem, Whence pendent many a pearly gem, Displays a milk-white bell;

Instinct with life thy fibrous root, Which sends from earth the ascending shoot As rising from the dead, And fills thy veins with verdant juice, Charged thy fair blossoms to produce, And bcrries scarlet red; 
The triple cell, the two-fold secd,

A ceaseless treasure-house decreed, Whence aye thy race may grow, As from creation they have grown, While spring shall weave her flowery crown, Or vernal breezcs blow;

Who forms thee thus, with unseen hand? Who at creation gave command,

And will'd thee thus to be ; And keeps thee still in being, through Age after age revolving! Who But the great God is he?

Omnipotent, to work his will; Wise, who contrives each part to fill The post to each assign'd ; Still provident, with sleepless care, To keep; to make thee sweet and fair For man's enjoyment-kind!

"There is no God," the senseless say:-

"O God! why cast'st thou us away i" Of feeble faith aud frail,

The molurner breathes his anxious thought;

By thee a better lesson taught, Sweet lily of the vale ?

Yes, He who made and fosters thee,

In reason's eye perforce nust be Of majesty divine 
Nor deems she, that his guardian case

Will He in man's support forbear,

Who thus provides for thine.

\section{THE FLOWER-GARUHY.}

\section{BY BARRY CORNWALL.}

'I'HERE the Kose uireils

Her breast of beauty, and each delicate bud $O^{\prime}$ the season comes in turn to bloom and perish. But first of all the Violet, with an eye Blue as the midnight heavens; the frail Snow-drop, Born of the breath of winter, and on his brow Fix'd like a pale and solitary star; The languid Hyacinth and pale Primrose, And Daisy trodden down like modesty; The Foxglove, in whose drooping bells the bee Makes her sweet music; the Narcissus, (named From him who died for love,) the tangled Wood. bine,

Lilacs, and flowering Limes, and scented Thorms, And some from the voluy tuous winds of June Catch their perfuminge 


\section{IHE LANGUAGE OF FLOWERS.}

\section{PART FIRST.}

Abecedars ........... Folubility.

Abatina ............... Fickleness.

Acacia............. Friendship.

Acacia, Rose or White.Elegance.

Acacia, Yellow........ Secret love.

Acanthus............The fine arts. Artifice.

Acalia............... Temperance.

Achillea Millefolia ..... War.

Achimenes Cupreata... Such worth is rare.

Aconite (Wolfsbane)...Misanthropy.

Aconite, Crowfoot..... Lustre

Adonis, Flos..........Sad memories.

African Marigold...... Vulgar minds.

Agnus Castus.......... Coldness, Indifference.

Agrimony .............. Thankfulness. Gratitude.

Almond (Common).....Stupidity. Indiscretion.

Almond (Flowering)...Hope.

Almond, Laurel......... Perfidy.

Allspice ............... Compassion.

Aloe................ Grief'. Religious super'stition. 
Althæa Frutex (Syrian

Mallow) ...........Persuasion.

Alyssum (Swcet)...... Worth beyonè beauty. Amaranth (Globe)..... Immortality. Unfading

Amaranth (Cockslove.

comb).............Foppery. Affectation. Amaryllis...........Pride. Timidity. Splendid beauty.

Ambrosia ........... Love returned.

American Cowslip..... Divine beauty.

American Elm........Patriotism.

American Linden...... Alatrimony.

American Starwort... Welcome to a stranger.

Amethyst.............Admiration.

Cheerfulness in old age.

Andromeda.......... Self-sacrifice.

Anemone (Zephyr

Flower) ............Sickness. Expectation.

Anemone (Garden)...FFrsaken.

Angclica............. Inspiration, or Magic.

Angrec.............. Royalty.

Apricot (Blossom).... Doubt.

Apple .............. Temptation.

Apple (Blossom).......Preference. Fame speaks

Apple, Thorn........ Doceitful churms.

A pocynum (Dogsbane) Deceit.

Irbor Vitw......... Unchunging friendship. Live for me.

Arum (Wake Robin)...Ardor. Zeal.

Ash-leaved Trumpet

Flower............. Separation.

Ash, Mountain......... Prudence, or With me yous

are safe. 
Ash Tree...........Grandeur:

Aspen Tree............. Lamentation, or fear. Aster (China)........ Variety. Afterthought. Asphodel.............. My regrets foilow you to

the grave.

Aurieula.............Painting.

aurieula, Searlet.......Avarice.

Austurtium...........Splendor.

Azalea............. Temperance.

Bachelor's Buttons.... Celibacy.

Baln................Sympathy.

Balm, Gentle.......... Pleasantry.

Balm of Gilead.......... Cure. Retief.

Balsam, Red.......... Touch menot. Impatient resolves.

Balsam, Yellow....... Impatience.

Barberry ............ Sharpness of temper.

Basil............... Hatred.

Bay Leaf............ I change but in death.

Bay (Rose) Rhododendron ............... Danger. Beware.

Bay Tree............. Glory.

Bay Wreath........... Reward of merit.

Bearded Crepis.........Protection.

Beech Tree........... Prosperity.

Bee Orehis........... Industry.

Bee Ophrys............ Error.

Begonia............. Deformity.

Belladonna.......... Silence. Hushs

Bell Flower, Pyramidal ................ Constancy.

Bell Flower (small white)............ Gratitude.

Belvedere .......... I declare against you 
Betony.............. Surprise.

Bilberry.............. Treachery.

Bindweed, Great....... Insinuation.

Bindweed, Small...... nity Hility.

Bireh............... Meekness.

Birdsfoot, Trefoil...... Revenge.

Bittersweet; Night-

shade ............ Truth.

Black Poplar......... Courage.

Blackthorn............ Diffculty.

Bladder Nut Tree..... Frivolity. Amusement.

Bluebottle (Centaury). Delicacy.

Bluebell............ Constancy. Sorrowful res

Blue-flowered Greek gret.

Valerian........... Rupture.

Bonus Henricus......Goodness.

Borage ............... Bluntness.

Box Tree............... Stoicism.

Bramble...............Lowliness. Envy. Ro morse.

Branch of Currants... You please all.

Braneh of Thorns.... Severity. Rigor.

Bridal Rose.......... Happy Love.

Broom ............. Humitity. Neatness.

Browallia Jamisonii... Could you bear poverty \&

Buckbean ........... Calm repose.

Bud of White Rose.... Heart ignorance of love.

Buglos..............Falsehood.

Bulrush ................ Indiscretion. Docility.

Bundle of Reeds, with

their Panieles.......Music.

Burdock ............ Importunity. Touch m. not. 
Bur..............Rudeness. You weary me. Buttereup (Kingeup).. Ingratitude. Childishness. Butterfly Orchis....... Gayety.

Buttertly Weed....... Let me go.

Cabbage .............Profit.

Caealia...............Adulation.

Cactus.............Warmth.

Calla Athiopiea...... Magnificent beauty:

Caleeolaria ..........I offer you pecuniary as. sustance, or I offer you my fortune.

Calycanthus.......... Benevolence.

Camellia Japonica, Red .............. Unpretending excellence.

Camellia Japonica, White........... Perfected loveliness.

Camomile.............Energy in adversity.

Campanula Pyramida. Aspiring.

Canary Grass.........Perseverance.

Candytuft ............. Indifference.

Canterbury Bell.......Acknowledgment.

Cape Jasmine........ I am too happy.

Cardamine............. Paternal error.

Carnation, Deep Red.. Alas! for my poor hearh

Carnation, Striped.... Refusal.

Carnation, Yellow....Disduin.

Cardinal Flower....... Distinction.

Catchfly............ Snare.

Catchfly, Red......... Youthful love.

Catehfly, White........ Betrayed.

Cattleya............ Mature charms.

Cattleya Pineli......... Matronly grace.

Cedar..............Strength.

Cedar of Lebanon..... Incorruptible. 
Cedar Lcaf.......... I live for thee.

Celandine (Lesscr).... Joys to come.

Cereus (Creeping)...... Modest genius.

Centauty........... Delicacy.

Champiruon............Suspicion.

Checkered Fritillary..Persecution.

Cherry Trcc, White... Good education.

Cherry Tree, Whitc...Deception.

Chestnut Tree........ Do me justice.

Chinese Primrose..... Lasting love.

Chickweed........... Rendezvous.

Chiccor'y ............ Frugality.

China Aster...........Variety.

China Aster, Double.. I partake your sentiments.

China Aster, Singlc... Twill think of it.

China or Indian Pink... Aversion.

China Rose.......... Beauty always new.

Chinese Chrysanthe- Cheerfulness under ad mum ........... versity.

Chorozcma Varium.... You have many lovers.

Christmas Rose....... Relieve my anxiety.

Chrysanthemum, Red.I love.

Chrysanthemum,

White............Truth

Chrysanthemum, Yel-

low.............. Slighted love.

Cineraria ............ Always delightful.

Cinquefoil ...........Maternal affection.

Circæa .............Spell.

Cistus, or Rock Rose.. Popular favor.

Cistus, Gum.........I shall die to-morrow.

Citron............Ill-natured beauty.

Clarkia ............. The variety of your conversation delights me.

Clematis Mental beauty. 
Clematis, Evergreen... Poverty.

Clianthus........... Worldtiness. Self-seeking.

Clotbur ............ Rudeness. Pertinacity.

Cloves..............Dignity.

Clover, Four-leaved... Be mine.

Clover, Red ...........Industry.

Clover, White ........Think of me.

Cobæa..............Gossip.

Coekseomb Amaranth. Foppery. Affectation.

Colchieum, or Meadow

$$
\text { Singularity. }
$$

Saffron ...........My best days are past.

Coltsfoot ............ Justiee shall be done.

Columbine .............Folly.

Columbine, Purple.... Resolved to win.

Columbine, Red.......Anxious and trembling.

Convolvulus ........... Bonds.

Conrolvulus, Blue (Minor)..........Repose. Night.

Convolvulus, Major... Extinquished hopes.

Convolvulus, Pink.... Worth sustained by judicious and tender affeco tion.

Corehorus ........... Impatient of absence.

Coreopsis .............. Always eheerful.

Coreopsis Arkansa.... Love at first sight.

Coriander ........... Hidden worth.

Corn ...............Riches.

Corn, Broken.........Quarrel.

Corn Straw...........Agreement.

Corn Bottle.......... Delicacy.

Corn Coekle.......... Gentility.

Cornel Tree........... Duration.

Coronella.............. Success erown your wishes. Cosmelia Subra...... The charm of a blush. 
Cowslip ............Pensiveness. Winning qrace.

Cowslip, American.... Divine beauty.

Crab (Blossom)....... Ill nature.

Cranberry ........... Cure for heartache.

Creeping Cereus.......Horror.

Cress ..............Stability. Poroer.

Crocus.............Abuse not.

Crocus, Spring........ Youthful gladness.

Crocus, Saffron........ Mirth.

Crown, Impcrial....... Hajesty. Power.

Crowsbill............Enzy.

Crowfoot............ Ingratitude.

Crowfoot (Aconiteleaved) ............ Lustre.

Cuckoo Plant.........Avior.

Cudweed, America... Unceasing remembrance. Currant ........... Thy frown will kill me. Cuscuta............ Meanness.

Cyclamen............ Diffidence.

Cypress........... Death. Mourning.

J) affodil .......... Regard.

Dahlia ............ Instability.

Daisy ............. Innocence.

Daisy, Garden........ I share your sertiments.

Daisy, Michaelmas.... Fareweil, or afterthought.

Daisy, Party-colored.. Beauty.

Daisy, Wild.........I I will thint of it.

Damask Rose........ Brilliant complexion.

Dandelion .......... Rustic oracle.

Daphne.............Glory. Immortality.

Daphne Odora.........Painting the lity.

Darnel ............ Vice.

Deaả Leaves. .........Sadness. 
Deadly Nightshade.... Falsehood.

Dew Plant............A serenade.

Dianthus .......... Make haste.

Diosma............. Your simple elegano

Dipteracanthus Speccharms me. tabilis............. Fortitude.

Diplademia Crassi-

noda............. You are too bold.

Dittany of Crete......Birth.

Dittany of Crete, White...........Passion.

Dock.................Patience.

Dodder of Thyme...... Baseness.

Dogsbane............Deceit. Falsehood.

Dogwood............ Durability.

Dragon Plant.........Snare.

Dragonwort .........Horror.

Dried Flax......... Utility.

Ebony Tree.......... Blackness.

Eehites Atropurpurea. Be voarned in time. Eglantine (Sweetbrier) ............ Poetry. I wound to heal.

Elder ..............Zealousness.

Elm.............. Dignity.

Enehanters Nightshade ............ Witcheraft. Sorcery.

Endive ............. Frugality.

Eseholzia........... Do not refuse me.

Eupatorium............Delay.

Everflowering Candy-

tuft .............. Indifference.

Evergreen Clematis... Poverty.

Evergreen Thorn..... Solace in adversity. 
Ererlasting ...........Never-ceasing remem brance.

Everlasting Pea.......Lasting pleasure.

Fennel ..........Worthy all praise. Strength.

Fern ..............Fascination. MTagic. Sim cerity.

Ficoides, Ice Plant.... Your looks freeze me.

Fig................. Argument.

Fig Marigold..........Idleness.

Fig Tree............ Prolific.

Filbert ................Reconcitiation.

Fir ............... Time.

Fir Tree............. Elevation.

Flax ............... Domestic industry. Fato.

Flax-leaved GoldenIfeel your kindness. locks ............Tardiness.

Fleur-de-lis........... Flame. I burn.

Fleur-de-Luce ........Fire.

Flowering Fern....... Reverie.

Flowering Reed....... Confulence in Heaven.

Flower-of-an-Hour .... Deticate beauty.

Fly Orchis........... Error.

Fly trap ............ Deceit.

Fool's Parsley......... Silliness.

Forget-Me-Not ........ True love.

Foxglove ............... Insincerity.

Foxtail Grass...........Sporting.

Franciscea Latifolia... Beware of false friends.

French Honcysuckle. Rustic beauty.

French Marigold.......Jealousy.

French Willow ......... Bravery and humanity.

Erog Ophrys......... Disgust. 
Fuller's Teasel.........Misanthropy.

Fumitory ............. Spleen.

Fuchsia, Scarlet...... Taste.

Furze, or Gorsc....... Love for all seasons.

Garden Anemone......Forsaken.

Garden Chervil........Sincerity.

Garden Daisy......... I partake your sentimenta

Garden Marigold...... Uneasiness.

Garden Ranunculus... You are rich in attractions.

Garden Sage.......... Esteem.

Garland of Roses...... Reward of virtue.

Gardenia...........Refinement.

Germander Speedrvell. Facility.

Geranium, Dark.......Melancholy.

Geranium, Horse-shoe Leaf ............. Stupidity.

Geranium, Ivy........Bridal favor.

Geranium, Lemon..... Unexpected meeting.

Geranium, Nutmeg.... Expected meeting.

Geranium, Oak-leaved. True friendship.

Geranium, Pencilled...Ingenuity.

Geranium, Rose-scented...............Preference.

Geranium, Scarlet.... Comforting.

Geranium, Silver-

leaved.............Recall.

Geranium, Wild...... Steadfast piety.

Gillyllower ...........Bonds of affection.

Gladioli.............. Ready armed.

Glory Flower......... Glorious beauty.

Goat's Rue...........Reasnn.

Goldeu Rod...........Precaution.

Gooseberry..... . Anticipation. 
Gourd.

Grammanthus Chlora-

flora. .............. Your temper is too hasty.

Grape, Wild..................

Grass .............. Submission. Utility.

Guelder Rose.........Winter. Age.

Hand Flower Tree.... Warning.

Harebell ............. Submission. Grief.

Hawkweed............. Quicksightedness.

Hawthorn ............ Hope.

Hazel...............Reconciliation.

Heartsease, or Pansy.. Thoughts.

Heath ............... Solitude.

Helenium ...........Tears.

Heliotrope........... Devotion, or I turn ts thee.

Hellebore ..............Scandal. Calumny.

Helmet Flower (Monkshood)............. Knight-errantry.

Hemloek ............. Tou will be my death.

Hemp............. Fate.

Henbane ........... Imperfection.

Hepatiea ............. Confidence.

Hibiscus............ Delicate beauty.

Holly............... Foresight.

Holly Herb............ Enchantment.

Hollyhock ............... Ambition. Fecundity.

Honesty............. Honesty. Fascination.

Honcy Flower... .... Love sweet and secret.

Honersuckle ........ Generous and devoted af.

Honeysuckle (Coral).. The color of my fate.

Honeysuckle (Freneh). Rustic beauty.

Hop................ Injustice.

Hornbeam.......... Ornament. 
Horse Chestnut....... Luxury.

Hortensia............ You are cold.

IIouseleek ............ Vivacity. Domestic Industry.

Houstonia ........... Content.

Iloya............... Sculpture.

Hoyibella ............ Contentment.

Humble Plant.......... Despondency.

Hundred-leaved Rose.Dignity of mind.

Hyaeinth.............Sport. Game. Play.

Hyaeinth, Purple.....hornowful.

Hyacinth, White...... Unobtrusive loveliness.

Hydrangea ............ boaster.

Hyssop.....................

Iceland Moss......... Health.

Ice Plant............ Your looks freeze me.

Imbricata............. Uprightness. Sentiments

Imperial Montague.... Power: of honor.

Indian Cress......... Warlike trophy.

Indian Jasmine (Ipoinœa) ..............Attachment.

Indian Pink (Double)... Aluays lovely.

Indian Plum..........P. Privation.

Iris. ................ Message.

Iris, German..........Flane.

Ivy.................Friendship. Fidelity.

Ivy, Sprig of, with Marriage. 'T'endrils............Assiduous to please.

Jacob's Ladder....... Come down.

Japau Rose........... Beauty is your mntey at traction. 
Jasmine............Amiability.

Jasmine, Cape........ Transport of joy.

Jasmine, Carolina..... Separation.

Jasmine, Indian.......I attach myself to you.

Jasmine, Spanish......Sensuatity.

Jasmine, Yellow....... Grace and elegance.

Jonquil.............I desire a return of affection

Judas Tree......... Unbetief. Betrayal.

Juniper...............Succor. Protection.

Justicia ............ The perfection of femalo loveliness.

Kennedia...........Mental beauty.

King-cups............ Desire of riches.

Laburnum........... Forsaken. Pensive Beauty.

Lady's Slipper........ Capricious beauty. Win

Lagerstræmia, Indian. Eloquence. me and wear me.

Lantana .............Rigor.

Lapageria Rosea...... There is no unalloyed good.

Lareh............Audacity. Boldness.

Larkspur............. Lightness. Levity.

Larkspur, Pink.......Fickleness.

Larkspur, Purple...... Iaughtiness.

Laurel

Iaurel, Common, in flower.............. Perfidy.

Laurel, Ground.........Perseverance.

Laurel, Mountain......Ambition.

Laurel-leaved Magnolia ............. Dignity. 
Laurestina ..........A token.

Lavender............ Distrust.

Leaves (dead).......... Melancholy.

Lemon .............. Zest.

Lemon Blossoms....... Fidelity in love.

Leschcnaultia Splendcus.............. You are charming.

Lettuce ............. Cold-heartedness.

Lichen ............... Dejection. Solitude.

Lilac, Ficld........... Humility.

Lilac, Purple.......... First emotions of love.

Lilac, White......... Youthful innocence.

Lily, Day............ Coquetry.

Lily, Imperial......... Majesty.

Lily, White..........Purity. Sweetness.

Lily, Yellow............. Falsehood. Gayety.

Lily of the Valley..... Return of happiness. On conscious sweetness.

Linden or Lime Trees. Conjugal love.

Lint................ Ifeel my obligations.

Live Oak............ Liberty.

Liverwort .......... Confidence.

Liquorice, Wild.......I Ieclare against you.

Lobelia..............Malevolence.

Locust Tree...........Elegance.

Locust Tree (green)... Affection beyond the grave.

London Pride......... Frivolity.

Lote Tree............ Concord.

Lotus...............Eloquence.

Iotus Flower......... Estranged love.

Lotus Leaf...........Recantation.

Love in a Mist........ Perplexity.

Love lies Bleeding..... Hopeless, not heartles.

Lucern ............. Life.

Lupine .............. Voraciousness. 
Madder............Calumny.

Magnolia ............. Love of Nature.

Magnolia, Swamp.....Perseverance.

Nallow .............. Mildness.

Mallow, Marsh........Benefieence.

Mallow, Syrian.......... Consumed by tove.

Mallow, Venetian...... Delieate beauty.

Malon Creeana........ Will you share my for-

Mauchineal Tree.......Falsehood.

Manórake............ Ilorror.

Maple...............Reserve.

Marianthus.......... Itope for better days.

Marigold ........... Grief.

Marigold, Afriean..... Vulgar minds.

Marigold, Freneh...... dealousy.

Marigold, Prophetie...Predietion.

Harigold and Cypress. Despair.

Marjoram............Blushes.

Marvel of Peru........ Timidity.

Meadow Lyehnis...... Wit.

Meadow Saffron.......My best days are past.

Meadorsweet ........ Uselessness.

Mereury............Goodness.

Mesembryanthemum ..Idleness.

Mezereon........... Desire to please.

Miehaclmas Daisy..... Afterthought.

Mignonetle ........... Your qualities surpass

Milfoil............ War. your charms.

Milkveteh........... Your presence softens $m y$

Milkwort ......... Hermitage.

Mimosa (Sensitive

Plant) ............. Sinsitiveness. 
Mint............... Virtue.

Mistletoe .............. I surmount difficulties.

Mitraria Cocciuea......Indolence. Dulness.

Mock Orange.......... Counterfeit.

Monarda Amplexicaulis............. Your w7ims are quite un bearable.

Monkshood ..........A deadly foe is near.

Monkshood (Helmet

Flower)..........Chivalry. Knight-erraintry.

Moonwort ........... Forgetfulness.

Morning Glory.........Affectation.

Moschatel ...........W Weakness.

Moss..............Maternal love.

Mosses.............Ennui.

Mossy Saxifrage......Affection.

Motherwort............ Concealed love.

Mountain Ash..........Prudence.

Mouruiug Bride...... Unfortunate attachment.

Mouse-eared ChickI have lost all. weed.............. Ingenuous simplicity.

Mouse-eared Scorpion grass.............. Forget me not.

Moving Plant..........Aditation.

Mudwort ............. Ilappiness. Tranquillity. Mulberry Tree (Black). I shall not survive you. Mulberry Tree (White). Wisdom.

Mushroom...........Suspicion, or I can't en

Musk Plant.......... Weakness. trrely trust you.

Mustard Seed......... Indifference.

Myrobalan.............Privation.

Myrrh............. Gladness. 
Myrtle.............Love.

Narcissus ..........Egotism.

Nasturtium ........... Patriotism.

Nemophila ............ Success everywhere.

Nettle, Common Stinging............... You are spiteful.

Nettle, Burning........ Slander.

Nettle Tree..........Conceit.

Night-blooming $\mathrm{Ce}$ reus............. Transient beauty.

Night Convolrulus.... Night.

Nightshade......... Falsehood.

Oak Leaves........... Bravery.

Oak Tree............. Flospitality.

Oak (White)........... Independence.

Oats...............The witching soul of

Oleander music.

Olive .................. Peace.

Orange Blossoms..... Your purity equals your lovetiness.

Orange Flowers....... Chastity. Bridal fes. tivities.

Orange Tree......... Generosity.

Orchis ............A belle.

Osier ...............Frankness.

Osmunda ............. Dreams.

Ox Eye............... Patience.

Palm .............. Fictomy.

Pansy ................. Thoughts.

Parsley............... Festivity.

Pasque Flower........ You have no claim. 
Passion Flower......Reliqious superstition, when the flower is reversed, or Faith if erect.

Patienee Dock........Patience.

Pea, Everlasting.......An appointed meeting. Lasting pleasure.

Pea, Sweet.......... Departure.

Peach ............... Your qualities, like your charms, are unequalled.

Peach Blossom........I am your captive.

Pear................Affection.

Pear Tree........... Comfort.

Penstemon Azureum...High-bred.

Penayroyal...........Flee away.

Peony ................. Shame. Bashfulness.

Peppermint...........Warmth of feeting.

Periwinkle, Blue...... Early friendship.

Periwinkle, White.....Pleasures of memory.

Persiearia...........Restoration.

Persimon................ Bury me amid Nature's beauties.

Peruvian Heliotrope... Devotion.

Petunia .............. Your presence soothes me.

Pheasant's Eye.......Remembrance.

Phlox ............... Unanimity.

Pigcon Berry.......... Indifference.

Pimpernel.............. Change. Assignation.

Pine................ Pity.

Pine-apple........... You are perfect.

Pine, Pitch............Philosophy.

Pine, Spruce.......... Hope in adversity.

Pink ................Bntilness.

Pink, Carnation........ Woman's Tove.

Pink, Indian, Double.. Alwoys lovaly.

Pink, Indian, Single... Aversion. 
Pink, Mountain........Aspiring.

Pink, Red, Double....Pure and ardent love.

Pink, Single...........Pure love.

Pink, Variegated....... Refusal.

Pink, White..........Ingeniousness. Talent.

Plantain........... White man's footsteps.

Plane Tree...........Genius.

Plum, Indian............Privation.

Plum Tree........... Fidelity.

Plum, Wild..........Independence.

Plumbago Larpenta... Holy wishes.

Polyanthus ........... Pride of riches.

Polyanthus, Crimson.. The heart's mystery.

Polyanthus, Lilac..... Confidence.

Pomegranate ......... Foolishness.

Pomegranate Flower...Mature elegance.

Poor Robin.......... Compensation, or an

Poplar, Black......... Courage.

equivalent.

Poplar, White.........Time.

Poppy, Red...........Consolation.

Poppy, Scarlet......... Fantastic extravagance.

Poppy, White..........Sleep. My bane.

Potato ..............Benevolence.

Potentilla...........I claim, at least, your

Prickly Pear.... .....Satire. esteem.

Pride of China........ Dissension.

Primrose ............ Early youth and sadness.

Primrose, Evening..... Inconstancy.

Primrose, Red........ Unpatronized merit.

Privet..............Prohibition.

Purple Clover..........Provident.

Pyrus Japonica....... Fairies' firo. 
Quaking-grass.........Agitation.

Quamochit...........Busybody.

Queen's Rocket........ You are the queen of

Quinee ............Temptation. coquettes. Fashion.

Ragged-robin........Wit.

Raununculus........... You are radiant with cnarms.

Kanuneulus, Garden.. You are rich in attrao tions.

Ranunculus, Wild..... Ingratitude.

Raspberry..........Remorse.

Ray Grass............ Vice.

Red Catehfy........... Youthful love.

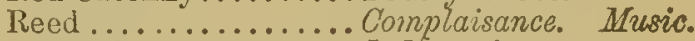

Reed, Split........... Indiscretion.

Rhododendron (Rose-

bay)............... Danger. Beware.

Rhubarb.............Aduice.

Roeket.............. Rivalry.

Rose.............. Love.

Rose, Austrian........ Thou art all that is lovely.

Rose, Bridal.......... Happy love.

Rose, Burgundy ...... Unconscious beauty.

Rose, Cabbage......... Ambassador of love.

Rose, Campion........ Only deserve my love.

Rose, Carolina......... Love is dangerous.

Rose, China ......... Beauty always newo.

Rose, Christmas ...... Tranquillize my anxiety

Rose, Daily.......... Thy smile I aspire to.

Rose, Damask ........ Brilliant complexion.

Rose, Deep Red........ Bashful shame.

Rose, Dog............ Piecisure and pain.

Rose, Guelder........ Winter. Age. 
Rose, Hundred-lıaved. Pride.

Rose, Japan .......... Beauty is your only at traction.

Rose, Maiden Blush... If you love me you will

Rose, Montiflora ...... Grace.

Rose, Mundi......... Variety.

Rose, Musk............ Capricious beauty.

Rose, Musk, Cluster...Charming.

Rose, Single.......... Simplicity.

Rose, Thornless........Early attachment.

Rose, Unique ......... Call me not beautiful.

Rose, White .......... I am worthy of you.

Rose, White (with-

ered )............ Transient impressions.

Rose, Yellow ......... Decrease of love. Jealowsy.

Rose, York and Lancaster ...........War.

Rose, Full-hlown,

placed over two

Buds ................ Secrecy

Rose, Wlite aud Red

together.......... Unis.

Roses, Crowu of...... Reward of virtue.

Rosebud, Red..........Pure and lovely.

Rosebud, White.......Girlhood.

Rosebud, Moss......... Confession of lova

Rosebud (Rbododen-

dron).............Rernare Transar

Rosemary ............. nemethururuc.

Ruäveckia..........

Rue .............. Disdain.

Rush.............. Docility.

Rye Urass........... Changeable disposition 
Saffron ............. Beware of excess.

Saffron Crocus........ Mirth.

Saffron. Meadow...... My happiest days are past.

Sage ............... Domestic virtue.

Sagc, Garden..........Esteem.

Sainfoin .............Agitation.

Saint Jobn's Wort.... Animosity

Salvia, Blue........Wisdom.

Salvia, Red...........Energy.

Saxifrage, Mossy.......Affection.

Scabious ........... Unfortunate love.

Scabious, Sweet....... Widowhood.

Scarlet Lychnis....... S'unbeaming eyes.

Schinus ........... Religious enthusiasm.

Scotch Fir...........Elevation.

Sensitive Plant........ Senisibility.

Senvy ............... Indifference.

Shanirock............ Light-heartedness.

Shepherd's Purse...... I offer you my all.

Siphocampylos ....... Resolved to be noticed.

Snakesfoot..........Horror.

Snapdragon ........... Presumption, also " No."

Snowball ............Bound.

Suowdrop ............ Hope.

Sorrel..............Affection.

Sorrel, Wild......... Wit ill-timed.

Sorrel, Wooa...........Joy.

Southernwood ........Jest. Bantering.

Spanish Jasmine...... Sensuality.

Spearmint.......... Warmth of sentiment.

Speedwcll ........... Female fidelity.

Speedwell, Germander. Facility.

Specdwell, Spiked....Semblanu,e.

Spider Ophrys........Adroitness.

Spiderwort..........Esteem, not love. 
Spiked Willow Herb.. Pretension.

Spindle Tree......... Your charms are engraven

Star of Bethlehem.... Purity. on my heart.

Starwort.............Afterthought.

Starwort, American... Cheerfulness in old age. Stephanotis.......... Will you aceompany mo to the East?

Stock .............. Lasting beauty.

Stock, Ten Wcek.....Promptness.

Stonecrop ...........Tranquillity.

Straw, Broken........ Rupture of a contract.

Straw, Whole........ Union.

Strawberry Blossoms. . Foresight.

Strawberry Tree...... Esteem, not love.

Sultan, Lilac......... I fargive you.

Sultan, White......... Sroeetness.

Sultan, Yellow........ Contempt.

Sumach, Venice.......Splendor.

Sunflower, Dwarf.....Adoration.

Sunflower, T'all....... Haughtiness.

Swallow-wort. . . . . . . Cure for heartacho.

Sweet Basil.......... Good wishes.

Sweetbrier, American. Simplicity.

Sweetbricr, European. I wound to heal.

Sweetbrier, Yellow.... Decrease of love.

Sweet Pea........... Delicate pleasures.

Sweet Sultan.........Felicity.

Sweet William.......Gallantry.

Sycamore........... Curiosity.

Syringa ............. Memory.

Syringa, Carolina..... Disappointment.

Tamarisk........... Crime.

Tansy (Wild)......... I d?clare voar against you. 
Teasel...............Misanthropy.

Tendrils of Climbing

Plants.............Ties.

Thistle, Common........Austerity.

Thistle, Fuller's........ Misanthropy.

Thistle, Scotch........ Retatiation.

Thorn Apple......... Deceitful charms.

Thorn, Branch of ..... Severity.

Thrift ................. Sympathy.

Throatwort .............. Negtected beauty.

Thyme ................ Activity or courage.

Tiger Flower........... For once may pride be

Traveller's Joy........Safety. friend me.

Tree of Life.......... Old age.

Trefoil................ Revenge.

Tremella Nestoc....... Resistance.

Trillium Pictum......... Mlodest beauty.

Triptiliou Spinosum... Be prudent.

Truffle ..............Surprise.

Trumpet Flower....... Fame.

Tuberose ............ Dangerous pleasures.

Tulip, Red........... Dectaration of love.

Tulip, Variegated...... Beautiful eyes.

Tulip, Yellow.......... Hopeless love.

Turnip.............. Charity.

Tussilage (Sweetscented)........... Justice shall be done you.

Valerian ...........An accommodating dispo.

Valerian, Greek....... Rupture.

Venice Sumach....... Intellectual excellence.

Venus's Car.......... Splendor.

Splendor.
Fly with me. 
Venus's Looking-glass. Flattery.

Venus's Trap ......... Deceit.

Verbcna, Pink........Family union.

Verbena, Scarlet..... Unite against svil, or Church unity.

Verbena, White......Pray for me.

Vernal Grass.........Poor, but happy.

Veronica ............Fidelity.

Veronica Speciosa .... Keep this for mysaks,

Vervain ............Enchantment.

Vine ............... Intoxication.

Violet, Blue ..........Faithfulness.

Violct, Dame........Watchfulness.

Violet, Sweet.........Modesty.

Violet, Yellow ........ Rural happiness.

Virginia Creeper...... I ciing to you both in sum shine and shade.

Virgin's Bower........ Filial love.

Viscaria Oculata...... Will you dance with me

Volkamenia........... May you be happy.

Walnut ............ Intellect. Stratagem.

Wall-flower............ Fidelity in adversity.

Watcher by the Wayside............... Never despair.

Water Lily .......... Purity of heart

Water Melon........... Bulkiness.

Wax Plant.............Susceptitility.

Wheat Stalk.......... Riches.

Whin ......................

White Jasmine........ Amiability.

White Lily ............ Purty and nodesty.

White Mullein ........Good-nature.

White Oak........... Independence.

White Pink.......... Talent. 
White Poplar.........Time.

White Rose (dried).... Death preferable to loss of innocence.

Whortleberry........Theason.

Willow, Creeping ........ Love forsaken.

Willow, Water......... Freedom.

Willow, Weeping ...... Mourning.

Wrillow Herb.......... Pretension.

Willow, French........ Bravery and humanity.

IVinter Cherry........ Deception.

Wisteria ............ Welcome, fair stranger.

Witch Hazel............A spell.

Woodbine.............. Froternal love.

Wood Sorrel...........Joy. Maternal tenderness.

Wormwood............Absence.

Xanthium ........... Rudeness. Pertinacity.

Xeranthemum ......... Cheerfulness under adver. sity.

Yew................Sorrow.

Zephyr Flower....... Expectation.

Zinnia ............ Thoughts of absent friends. 
PAR' SECOND.

Absence............. Wormwood.

Abuse not........... Crocus.

Acknowledgment ..... Canterbumy Bell.

Activity, or Courage.. Thyme.

A deadly foe is near... Monkstiood.

Admiration............ Amethyst.

Adoration ........... Dwarf Sunflower.

Adroitness ............ Spider Ophrys.

Adulation.............. Cacalia.

Advice ............. Rhubarb.

Affection .............. Mossy Saxifrage.

Affection .............. Peat.

Affection ................ Sompel.

Affection beyond the

grave............ Green Locust.

Affection, maternal.... Cinquefoil.

Affectation........... Coctiscomb Amaranth.

Affectation............. Morning Glory.

Afterthought.......... Nichaelmas Daisy.

Afterthought........... Starwort.

Afterthought............. China Aster.

Agreement ........... Straw.

Age ................ Guelder Rose.

Agitation................ Moving Plant.

Agitation.............. Sainfoin.

Alas! for my poor

heart.............. Deep Red Carnation.

Always cheerful....... Coreopsis. 
Always lovely......... Indian Pink (double).

Always delightful...... Cineraria.

Ambassador of love... Cabbage Rose.

Amiability......... Jasmine.

Anger.............Whin, or Gorse.

Animosity ............... John's Wort.

Anticipation...........Gooseberry.

Anxious and trembling. Red Columbine.

Ardor, Zeal........... Cuckoo Plant. Amum.

Argment ...........Fig.

Arts, or Artifice........ Acanthus.

Assiduous to please... Sprig of ivy with tendrils.

Assignation.......... Pimperne?.

Attachment........... Indian Jasmine.

Audacity ............. Larch.

Avarice............ Scarlet Auricula.

Aversion ............... China, or Indian Pink.

Bantering........... Southernwoood.

Baseness ............. Dodder of Thyme.

Bashfulness............ Peony.

Bashful shame......... Deep Red Rose.

Be prudent........... Triptition Spinosum.

Be warned in time.... Echites Atro-purpurea.

Beautiful eyes........ Variegated Tulip.

Beanty .............. Parti-colored Daisy.

Beauty always new.... China Rose.

Beauty, capricious ....Lady's Slipper.

Bcauty, capricious ..... Musk Rose.

Beauty, delicate ....... Flower of an hour.

Bcauty, dclicate .......Hibiscus.

Beauty, divine.......... American Coroslip.

Benuty, glorious........ Glory Flower.

Bcauty, lasting ........ Stock.

Beauty, magnificent... Colla Ethiopica. 
Beauty, mental........Clematis.

Beauty, modest........ Trillium Pictum.

Beauty, negleeted..... Throatwont.

Beauty, pensive........ Laburnum.

Beauty, rustic ......... French Honeysuckls.

Beauty, uneonseious... Burgundy Rose.

Beauty is your only

Belle .............. Orchis.

Be mine................ Fon-leaved Clover.

Beneficence............Marshmallow.

Benerolenee ........... Potato.

Betrayed ............ White Catchfly.

Beware............. Oleander.

Beware.............Rosebay.

Beware of a false

friend ............ Franciscea Latifolia

Blackness ........... Ebony T'ree.

Bluntmess .............. Borage.

Blushes .............. Marjoram.

Boaster............. Hydrangea.

Boldness ............ Pink.

Bonds.............. Convolvulus.

Bonds of Affection.... Gillyflower.

Bravery ............ Oak Leaves.

Bravery and humanity. French Willow.

Bridal favor.......... Ivy Geranium.

Brilliant eomplexion.. Damask Roso.

Bulk............ Water Melon.

Bulk............... Gourd.

Busybody .......... Quamoclit.

Bury me amid $\mathrm{Na}$ -

ture's beauties......Persimmon.

Call me not beautiful. . Rose Uniqun. 
Calm repose .......... Buckbean.

Calumny .............Hellebore.

Calumny .............Madder.

Change................ Pimpernel.

Changeable disposition .............. Rye Grass.

Charity ........... Turnip.

Charming.............. Cluster of Musk Roses.

- Charms, deceitful.....Thorn Apple.

Cheerfulness in old age............... Amorican Stamoort.

Cheerfulness under adversity .......... Chinese Chrysanthemum.

Chivalry ..............Monkshood.

Cleanliness...........Hyssop.

Coldheartedness ....... Lettuce.

Coldness .............Agnus Castus.

Color of my life....... Coral Honeysuckle.

Come down........... Jacob's Ladder.

Comfort ...............Pcar Tree.

Comforting ........... Scarlet Geranium.

Compassion ...........Allspice.

Concealed love........ Motherwort.

Concert ............. Nettle Trce.

Concord............. Lote Tree.

Confession of love......Moss Rosebud.

Confidence ...........Ilepatica.

Confidence ............ Lilac Polyanthus.

Confidence ............ Liverwort.

Confidence in Heaven. Flowering Reed.

Conjugal love......... Lime or Linden Tres.

Consolation........... Red Poppy.

Constancy............ Bluebell.

Consumed by love.... Syrian Mallow.

Contentment.......... Hoyabella. 
Could you bear poverty.............. Browallia Jamisonii. Counterfeit ............Mock Orange.

Courage............ Black Poplar.

Crime ............ Tamarist.

Cure .................. Balm of Gilead.

Cure for heartaehe.... Swallow-wort.

Curiosity .............Sycamore.

Danger.............. Thododendron Rosebay Dangerous pleasures...Tuberose. Death .............. Cypress.

Death preferable to loss of innoeenee.... White Rose (dried).

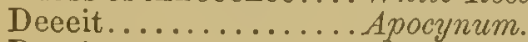

Deeeit.................. Flytrap.

Deeit................ Dogsbane.

Deeeitful eharms......Apple, Thorn.

Deeption ........... White Cherry Tree.

Deelaration of love.... Red Tulip.

Deerease of love...... Yellow Rose.

Deformed ...........Begonia.

Dejection............... Lichen.

Delay ................ Eupatorium.

Delieaey .............Bluebottle. Centaury.

Desire to please..........Mezereon.

Despair............... Cypress.

Despondeney ..........Humble Plant.

Devotion, or I turn to thee............... Peruvian Heliotrope.

Diffieulty ............. Blackthorn.

Dignity................. Cloves.

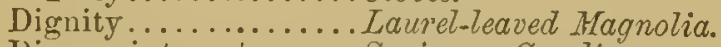

J)isappointment....... Syringa, Carolina.

Disdain............. Yellow Carnation. 
Disdain............Rue.

Disgust ...........Frog Ophrys.

Dissension........... Pride of China.

Distinction ........... Cardinal Flower.

Distrust .............Lavender.

Divine beauty.........American Cowslip.

Docility ............. Kush.

Domestic industry....Flax.

Domestic virtue...... Sage.

Do not despise my poverty............. Shepherd's Purse.

Do not refuse me......Eschcolzia, or Carrot Flower.

Doubt.............Apricot Blossom.

Durability .......... Dogwood.

Duration ............. Cornel Thee.

Early attachment..... Thornless Rose. Early friendship ....... Blue Periwinkle.

Early youth .......... Primrose.

Elegance ............ Locust Tree.

Elegance and grace... Yellow Jasmine. Elevation............. Scotch Fir.

Eloquence ............ Indian Lagerstramia

Enchantment.......... Holly Herb.

Enchantment.......... Vervain.

Energy..............Red Salvia.

Energy in adversity... Camomile.

Envy.............Bramble.

Error................Bee Orchis.

Error..............Fly Orchis.

Esteem............ Garden Sage.

Esteem, not love......Spiderwort.

Esteem, not love...... Strawberry Tree.

Estranged love.........Lotus Flower. 
Excellence..........Camellia Japonica.

Expectation ...........Anemone.

Expectation ........... Zephyr Flower.

Expected meeting......Nutmeg Geranium.

Exteut ............. Gourd.

Extinguished hopes... Major Convolvulus.

Facilitý.............Germander Speedwell.

Fairies' Fire........... Pyrus Japonica.

Faithfulness ........... Blue Violet.

Faithfulness .......... Heliotrope.

Falsehood ...........Bugloss. Deadly Night shade.

Falsehood .......... Yellow tily.

Falsehood ............Manchineal Tree.

Fame .............. Tulip.

Fame speaks him

great and good..... Apple Blossom.

Family union......... Pink Verbena.

Fantastic cxtrava-

gance ............... Scarlet Poppy.

Farcwell ..............tichaelmas Daisy.

Fascination.......... Fern.

Fascination..........Honesty.

Fashion ............... Queen's Rocket.

Fecundity ............. Hollyhock.

Felicity ............. Sweet Sultan.

Female fidelity......... Speedwell.

Festivity ........... Parsley.

Fickleness ...........Abatina.

Fickleness ........... Pink Larkspur.

Fidelity............ Veronica. Ivy.

Fidelity............... Plum Tree.

Fidelity in adversity... Wall-flower.

Fidelity in love....... Lemon Blossoms. 
Filial love............ Virgin's Bower.

Fire ................. Feur-de-Luce.

First emotions of love. Purple Lilac.

Flame.............. Fleur-lle-lis. Iris.

Flattery ................ Vonus's Looking-glass.

Flee away............... Pennyroyal.

Fly with me........... Venus's Car.

Folly .................. Columbine.

Foolishness............ Pomegranate.

Foppery.................. Aockscomb. Amaranth.

Foresight............Holly.

Forgetfulness .........Moonwort.

Fornt me not..........Forget-Me-Not.

Fur once may pride

befriena me.........Tiger Flower.

Forsaken ............ Garden Anemone.

Forsaken ............. Laburnum.

Fortitude............ Dipteracanthus Specta bilis.

Frankness .......... Osier.

Fraternal love........ Woodbine.

Freedom............ Water Willows.

Freshness ............ Damask Rose.

Friendship .............Acacia. Ivy.

Friendship, early.......... Blue Periwinkle.

Friendship, true ....... Oak-leaved Geranium.

Friendship, unchang-

ing................... Arbor Vitce.

Frivolity................... London Pride.

Frugality............... Chiccory. Endive.

Gallantry............Sweet William.

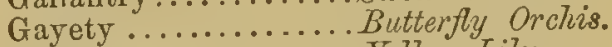

Gayety ............... Fellow Lily.

Generosity............ Orange Tree. 
Generons and devoted affection...........French Honeysuckle. G'enius .............. Ilane Tree.

Gentility.............. Corn Cockle.

Girlhood............. White Rosebud.

Give me your good

wishes............. Sweet Basit.

Gladness ................

Glory ............. Laurel.

Glory. Imnortality.. Daphne.

Glorious beauty....... Glory Flower.

Goodness............ Bonus Itenricus.

Gooduess.................ercury.

Good edueation ......... Chemy Tree.

Good wishes.......... Sweet Basil.

Good-nature .......... White Mullein.

Gossip............... Cobcea.

Grace ...............Multiflora Rose.

Grace and elegance... Yellow Jasmine.

Grandeur............Ash Tree.

Gratitude..........Small White Bell-flower

Grief .............Harebell.

Grief ............. Mlarigold.

Happy love.......... Bridal Rose.

Hatred ................Basil.

Haughtiness .......... Purple Larkspur.

Haughtiness .......... Tall Sunflowor.

Health ................. Iceland Moss.

Hermitage........... Milkwart.

Hidden worth ......... Coriander.

High-bred .............Penstemon Azureum.

Holy wishes............ Plumbago Larpenta.

Honesty............ Honesty.

Hope...............Flowering Almond. 
Bope............... Hawthorn.

Hope................ Snowdrop.

Hope in adversity..... Spruce Pine.

Hopeless love......... Yellow Tutip.

Hopeless, not heart-

less .............. Love Lires Blceding.

Horror ...............Manulrake.

Horror ............. Dragonswort.

Horror ............. Snakesfoot.

Hospitality ......... Oat Tree.

Humility ........... Broom.

Humility ........... Smant Bindweed.

Humility ........... Fie'd Lilac.

I am too happy....... Cape Jasmine.

I am your eaptive..... Peach Blossom.

I am worthy of you... White Rose.

I ehange but in death. Buy Leaf.

I elaim at least your esteem ............ Potentilla.

I dare not........... Feronica Speciosa.

I deelare agrainst you.. Betvillere.

I deelare agninst you.. Liquorice.

I deelare war against you..............Wild Tansy.

I die if negleeted...... Laurestinn.

I desire a return of affeetion............Jonquil.

I feel my obligations... Lint.

I feel your kindness... Flax.

I have lost all.........Mourning Bride.

I live for thee........... Cedar Leaf.

I love ...............Red Chrysanthemum.

I offer you my all..... Shepherd's Purse. 
I otfer you my fortune, or I offer you pecuniary aid ........... Calceolaria.

I share your sentiments............ Double China Aster.

I share your sentiments ........... Garden Daisy.

I shall dic to-morrow.. Gum Cistus.

I shall not survive you. Black Mulberry.

I surmount difficulties. Mistletoe.

I watch over you...... Mountain Ash.

I wecp for you......... Purple Verbena.

I will think of it........ Single China Aster.

I will think of it....... Wild Daisy.

I wound to heal.......Eglantine (Sweetbrier).

Idleness ............Mesembryanthemum.

If you love me, you will find it out..........Maiden Blush Rose.

Ill-nature............Crab Blossom.

IIl-natured beauty..... Citron.

Invagination .......... Lupine.

Immortality ......... Globe Amaranth.

Impaticnce ........... Yellow Balsam.

Impatient of absenee.. Corchorus.

Impatient resolves.... Red Balsam.

Imperfeetion......... Henbane.

Importunity ...........Burdock.

Inconstancy ...........Evening Primrose.

Incorruptible.......... Cedar of Lebanon.

Independence......... Wild Plum Tree.

Independenee......... White Oak.

Indifferenee........... Everflowering Candytuft.

Indifferenee...........Mustard Seed.

Indifferenee........... Pigeon Berry.

Indifference...........Senvy. 
Indiscretion .........Split Reed.

Indolence.............Mitraria Coccinea.

Indnstry............. Red Clover.

Indnstry, Domestic... Flax.

Ingeniousness........ White Pink.

Ingenuity............Pencilled Geranium.

Ingenuous simplicity. Mouse-eared Chickweed.

Ingratitude .......... Crowfoot.

Innocence............ Daisy.

Insincerity...........Foxglove.

Insinuation .......... Great Bindroeed.

Inspiration ............ Angelica.

Instability.......... Dahlia.

Intellect...........Walnut.

Intoxication ........ Vine.

Irony..............Sardony.

Jealousy............ French Marigold.

Jealousy............. Yellow Rose.

Jest ............... Southernwood.

Joy .............. Wood Sorrel.

Joys to come......... Lesser Celandine.

Justice.............Rudbeckia.

Justice shall be done to you.............. Coltsfoot, or Sroeet-8cented Tussilage.

Keep your promise.... Petunia.

Kindness .............Scarlet Geranium.

Knight-errantry....... Helmet Flower (Monkshood).

Lamentation..........Aspen Tree.

Lasting beauty............ Stock.

Lasting pleasures...... Everlasting $P_{\in}$. 
Let me go..........Buttergly Wheel.

Levity.............Larkspur.

Liberty ............ Live Oak.

Life ............... Lucern.

Lightheartedness......Shamrock.

Lightness............ Larkspur.

Live for me.........Arbor Vitce.

Love.................Mryrte.

Love...............Rose.

Love, forsaken........ Creeping Willon.

Love, returned.........Ambrosia.

Love is dangerous..... Carolina Rose.

Love for all seasons... Furze.

Lustre ............Aconite-leaved Crowfoot, or Fair Maid of France.

Luxury............ Chestnut Tree.

Magnifieent beauty... Calla Aithiopica.

Majesty............. Crown Imperial.

Make haste.......... Dianthus.

Malevolenee ..........Lobelia.

Marriage ............ Ioy.

Maternal affeetion..... Cinquefoil.

Maternal love.........Moss.

Maternal tenderness... Wood Sorrel.

Matrimony...........American Linden.

Matronly graee....... Cattleya.

Mature eharms........ Cattleya Pineli.

May you be happy.... Volkamenia.

Meanness........... Coscuta.

Mleelness............Birch.

Mrclaneholy ..........Dark Geranium.

Nelaneholy ........... Dead Leaves.

Mental beauty........ Clematis.

Mental beauty.........Kennedia. 
Message ............ Iris.

Mildness.............. Mallow.

Mirth............... Saffron Crocus.

Misanthropy.........Aconite (Wolfsbans).

Misanthropy..........Fuller's Teazle.

Modest beauty........ Trillium Pictum.

Modest genius......... Creeping Cereus.

Modesty............. Viotet.

Modesty and purity... White Lily.

Momentary happiness. Virginian Spiderwort.

Mourning ............Weeping Willow.

Music.............Bunlles of Reeds with their Panicles.

My best days are past. Colchicum, or Meadowo

My regrets follow you

Saffron.

to the grave.........Asphodel.

Neatness ............Bronm.

Neglected beauty..... Throatwort.

Never-ceasing remem-

brance.............Everlasting.

Never despair......... Watcher by the Wayside.

No ................Snapdragon.

Old age............ Tree of Life.

Only deserve my love.. Campion Rose.

Painful recollections... Flos Adonis.

Painting..............Auricula.

Painting the lily.........Daphne Odora.

Passion ............ White Dittany.

Paternal error.......... Cardamine.

Patience...............Dock. Ox Eys.

Patriotism............American Elm. 
Patriotism........... Nasturtium.

Peace................. Olive.

Perfected loveliness... White Camellia JaPerfidy............... common Laurel, in

Pensive beauty........thaburnum.

Perplexity............ Love in a Mist.

Persecution............ Checkered Fritillary

Perseverance............Swamp Mragnolia.

Persuasion...........Althea Frutex.

Persuasion............ Syrian Mallow.

Pertinacity ............ Clotbur.

Pity ................... Pine, atso Andromeda

Pleasure and pain..... Dog Rose.

Pleasure, lasting....... Everlasting Pea.

Pleasures of memory.. White Periwinkle. Popular favor.......... Cistus, or Rock Rose. Poverty ..............Evergreen Clematis. Power............. Imperial Montague.

Power.............. Cress.

Pray for me........... White Verbena.

Precaution.............. Golden Rod.

Prediction ............. Prophetic Marigold.

Pretension .............. Spiked Willow Herb.

Pride.................. Hundred-leaved Rase.

Pride ............... Amaryllis.

Privation ............ Indian Plum.

Privation ............. Myrobalan.

Profit................. Cabbage.

Prohibition ............Privet.

Prolific................Fig Tree.

Promptuess ............ Ten-2veek Stock.

Prosperity............Beech Tree.

Protection ................ Bearded Crepis. 
Prudence ............Mountain Ash.

Pure love.............Single Red Pink.

Pure and ardent Jove.. Double Red Pink.

Pure and lorely.......Red Rosebud.

Purity............... Star of Bethlehem.

Quarrel............Broken Corn-strawo.

Quicksightedness ...... Hawkweed.

Ready armed.........Gladioti.

Reason .............Goat's Rue.

Recantation ........... Lotus Leaf.

Recall ............... Silver-leaved Geraninm.

Reconciliation .........Filbert.

Reconciliation ..........Fazel.

Refinement ........... Gardenia.

Refusal.............. Striped Carnation.

Regard ............. Daffodil.

Regret.............Purple Verbena.

Relief ............... Balm of Gilead.

Relieve my anxiety...Christmas Rose

Religious superstition. Aloe.

Religious superstition,

or faith............Passion Flower.

Religious enthusiasm. .Schinus.

Remembrance........Rosemary.

Remorse ........... Bramble.

Remorse ...........Raspberry.

Rendezvous ...........Chichweed.

Reserve ............Maple.

Resistance........... Tremella Nestoc.

Resolved to be noticed.Siphocampylos.

Restoration..........Persicaria.

Retaliation............ Scotch Thistle.

Return of happiness... Lily of the Valley. 
Revenge............Birdsfoot Trefoil.

Reverie ..............Flowering Fern.

Reward of merit.......Bay Wreath.

Reward of virtue..... Garland of Roses.

Riches.............. Corn.

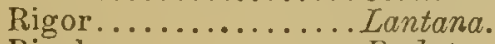

Rivalry..............Rocket.

Rudeness.............Clotbur.

Rudeness............Xanthium.

Rural happiness....... Yellow Violet.

Rustic beauty.......... French Honeysuckle.

Rustic oracle.........Dandelion.

Sadness............ Dead Leaves.

Safety.............. Traveller's Joy.

Satire............. Prickly Pear.

Sculpture........... Hoya.

Secret love........... Yellow Acacia.

Semblance............ Spiked Speedwell.

Sensitiveness .........Mimasa.

Sensuality..........Spanish Jasmine.

Separation........... Carolina Jasmine.

Severity.............Branch of Thorns.

Shame.............Peony.

Sharpness............Barberry Tree.

Sickness.............. Anemone (Zephyr Floroer).

Silliness..............Fool's Parstey.

Simplicity ..........American Sheetbrier.

Sincerity...........Garden Chervil.

Slighted love........ Yellow Chmisanthemum.

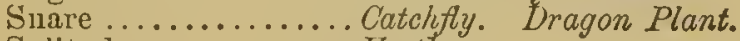

Solitude............. Hcath.

Sorrow............ Yew.

Sourness of temper... Barberry.

Spell...............Circa. 
Spleen .............. Fumitory.

Splendid beauty....... Amaryllis.

Splendor ............. Austurtium.

Sporting.............Fox-tail Grass.

Steadfast piety.......W Wild. Goranium.

Stoieism ............Box Tree.

Strength ....................... Fennel.

Stupicity............. Horseshoc-leaf Geranium

Submission..........Grass.

Submission............Harebell.

Success everywhere... Nernophita.

Suecess erown your

wishes............ Coronella.

Sueeor .............. Juniper.

Such worth is rare.... Achimenes.

Sunbeaming eyes..... Scarlet Lychnis.

Surprise ............ Truffle.

Suseeptibility .......W Wax Plant.

Suspieion .............. Champignon.

Sympathy ............. Balm.

Sympathy ........... Thrift.

Talent............. White Pink.

Tardiness..............Flax-leaved Golden-locks.

Taste .............. Scarlet Fuschia.

Tears............... Helenium.

Temperanee..........Azalea.

Temptation...........Appls.

Thankfulness .......... Agrimony.

The eolor of my fate... Coral Honeysuckle.

The heart's mystery... Crimson Polyanthus.

The perfeetion of fe-

male loveliness....... Justicia.

The witehing soul of

music ............ Oats 


\section{2}

THE LANGUAGE OF FLOWERS.

The rariety of your conversation delights me.......... Clarkia.

There is no unalloyed good ............. Lapagenia Rosea.

Thoughts........... Pansy.

Thoughts of absent friends ............. Zinnia. Thy frown will kill me. Currant. Thy smile I aspire to. . Daily Rose. Ties...............Tendrils of Climbing Plants.

Timidity............Amaryllis.

Timidity................

Time .............. White Poplar.

Tranquillity ........... Mudwort.

Tranquillity ............. Stonecrop.

Tranquillize my anx-

1ety............ Christmas Rose.

Transient beauty........ Night-blooming Cereus.

Transient impressions. Withered White Rose.

Transport of joy...... Cape Jasmine.

Treachery ............Bitberry.

True love.............. Forget-me-not.

True friendship....... Oak-leaved Geranium.

Truth ..............Bittersweet Nightshade.

Truth ............. White Chrysanthemum.

Unanimity .........P.Phlox.

Unbelief............. Judas Tree.

Unceasing remem-

brance.............American Cudroeed.

Unchanging friendship..............Arbor Vitce.

Unconsclous beauty... Burgundy Rose. 
Unexpected meeting...Lemon Geranium.

Unfortunate attachment .............Mourning Bride.

Unfortunate love......Scabious.

Union ............. Whate Straw.

Unity............ White and Red Rose to

Unite against a comgether.

mon foe...........Scarlet Verbena.

Unpatronized merit... Red Primrose.

Uprightness ..........Imbricata.

Uselessness........... Meadowsweet.

Utility.............. Grass.

Variety ..............hina Aster.

Variety ............Mundi Rose.

Vice............... Darnel (Ray Grass).

Victory.............Palm.

Virtue................Mint.

Virtue, domestic...... Sage.

Volubility ............Abecedary.

Voraciousness ......... Lupine.

Vulgar minds..........African Marigold.

War................ York and Lancaster Kose.

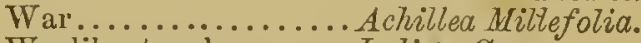

Warlike trophy....... Indiain Cress.

Warmth of feeling..... Peppcrmint.

Watchfulness......... Dame Violet.

Weakness .............Moschatel.

Weakness ...........Musk Plant.

Welcome, fair stranger. Westeria.

Welcome to a stranger. American Starwort.

Widowhood........... Sweet Scabious. 
Will you accompany

me to the East?.... Stephanotis.

Will you dance with

me?............. riscaria Oculata.

II in me and wcar mc. . Lady's Slipper.

Winning grace....... Cowslip.

Winter age.......... Guelder Rose.

Wisd om ........... Blue Satvia.

Wit .............. Heawow Lychnis.

Wit ill-timed..........Wild Sorrel.

Witchcraft............Enchanter's Nightshade.

Worth beyond beauty. Sweet Elysium.

Worth sustained by judicious and tender affection.........Pink Convolvulus.

Worldliness, selfseeking.............Clianthus.

Worthy of all praise...Fennel.

You are cold..........Flortensia.

You arc my divinity... American Cowstip.

You are perfect........ Pine Apple.

You arc radiant with charms ..........Ranunculus.

You are rich in attraction .......... Garden Ranunculus.

You are the queen of coquettcs.......... Queen's Rocket.

You are charming..... Leschenaultia Splendens.

You have no claims... Pasque Flower.

You have many lovers. Chorozema Varium.

You plcase all........Branch of Currants.

You arc too bold...... Diplademia Crassinoda.

You will be my death. Hemlock. 
Your charms are en-

graven on my beart. Spindle Tree.

Your looks ficeze me.. Ice Plant.

Your presence softens my pain........... Milkvetch.

Your purity equals your loveliness...... Orange Blossoms.

Your qualities, like your charms, are uuequalled ..........Peach.

Your qualities surpass your charms.........Mignonette.

Your temper is too hasty............. Grammanthes Chloraflora. Youthful innocence... White Lilac.

Youthful love.........Red Catchfly.

Your whims are unbearable........... Monarda Amplexicaulis.

Zealousness ..........Elder.

Zest................ Lemon. 


\section{MODIFICATIONS OF THE FLOWER LANGUAGE.}

IF a flower be given reversed, its original signification is understood to be eontradieted, and the opposite meaning to be implied.

A rosebud divested of its thorns, but retaining its leaves, eonveys the sentiment, "I fear no longer; I hope;" thorns signifying tears, and leaves hopes.

Stripped of leaves and thorns, the bud signifies, "There is nothing to hope or fear."

The expression of flower's is also varied by changing their positions. Place a marigold on the head, and it signifies "Mental anguish;" on the bosom, "Indifference."

When a flower is given, the pronoun $d$ is understood by bending it to the right hand; thou, by inclining it to the left.

"Yes" is implied by to uching the flower given with the lips. away.

"No," by pinching off" a petal, and easting it

"I am," is expressed by a laurel-leaf twisted round the bouquet.

"I have," by an ivy-leaf folded together.

"I offer you," by a leaf of the Virginian Creeper. 


\section{BOUQUETS AS EXAMPLES. \\ SPRING.}

1.

May maternal love protect your early youth in innoconce and joy!

\section{Flowers needed.}

Moss............... Maternal Love.

Bearded Crepis........Protect.

Primroses ............Early youth.

Daisy .....................nnocence.

Wood Sorrel..........Joy.

\section{SUMMER.}

2. love.

Your humility and amiability have won my Flowers needed.

Broom ............. Humility.

Whitc Jasmine........ Amiability.

Myrtle.............. Love.

3.

Let the bonds of marriage unite us.

Flowers needed.

Blue Convolvulus..... Bonds. 
Ivy.............. Marmiage.

A few whole straws... Unite us.

4.

A Farewell.

Farewell! give me your good wishes. Forget me not.

Hilowers needed.

Sprig of Spruce Fir... Farewell.

Siweet Basil........... Give me your good wishes. Forget-Me-Not........ Forget me not.

5.

Your patriotism, courage, and fidelity merit everlasting remembrance.

Flowers needed.

Nasturtium ..........Patriotism.

Oak Leaves........... Courage.

Heliotrope........... Fidelity.

Everlasting, or Im-

mortelles..........Everlasting remembrance.

6.

A Red Rose.......... I love you.

7.

AN IMPERTINENCE.

Your insincerity and avarice malre mu hate you.

Flower's needed.

Cherry Blossom, or

Fuxglove..........Insincerity. 
Scarlet Auricula.......Avarice.

Turk's Cap........... Hatred.

8.

A Warning.

Beware of deceit. Danger is near. Depart.

Flowers needed.

Oleander............ Beroare.

White Flytrap........ Deceit.

Rhododendron....... Danger is near.

Sweet Pea.......... Depart.

9.

A RebuKe.

Your frivolity and malevolence will cause you to be forsaken by all.

Illowers needed.

London Pride.........Frivotity.

Lobelia...............Malevolence.

Laburnum............Forsaken.

\section{AUTUMNAL.}

10.

Be assured of my sympathy. May you find consolation!

Elowers needed.

Thrift.............. Be assured of my sym-

Red Poppy............ Cor solation. 
820

THE LANGUAGE OF FLOWERS.

\section{WINTER.}

11.

By foresight you will surmount your difficulties.

Flowers needed.

Holly............... Foresight.

Mistletoe............ You will surmount your difficulties 



$$
\begin{aligned}
& \text { Y } \\
& \text { Caingd } 11046 \\
& \text { 9) } \\
& \text { as } 8
\end{aligned}
$$




